\title{
Compositions of Criticism: A Reinterpretation of Gustave Courbet's Paintings of Nudes
}

Amanda M. Guggenbiller

Follow this and additional works at: https://researchrepository.wvu.edu/etd

\section{Recommended Citation}

Guggenbiller, Amanda M., "Compositions of Criticism: A Reinterpretation of Gustave Courbet's Paintings of Nudes" (2014). Graduate Theses, Dissertations, and Problem Reports. 5721.

https://researchrepository.wvu.edu/etd/5721

This Thesis is protected by copyright and/or related rights. It has been brought to you by the The Research Repository @ WVU with permission from the rights-holder(s). You are free to use this Thesis in any way that is permitted by the copyright and related rights legislation that applies to your use. For other uses you must obtain permission from the rights-holder(s) directly, unless additional rights are indicated by a Creative Commons license in the record and/ or on the work itself. This Thesis has been accepted for inclusion in WVU Graduate Theses, Dissertations, and Problem Reports collection by an authorized administrator of The Research Repository @ WVU. For more information, please contact researchrepository@mail.wvu.edu. 


\title{
Compositions of Criticism: \\ A Reinterpretation of Gustave Courbet's Paintings of Nudes
}

\section{Amanda M. Guggenbiller}

\author{
Thesis submitted to the \\ College of Creative Arts \\ at West Virginia University \\ in partial fulfillment of the requirements for the degree of
}

\author{
Master of Arts \\ in \\ Art History
}
Rhonda Reymond, Ph.D., Chair
Janet Snyder, Ph.D.,
J. Bernard Schultz, Ph.D.

School of Art and Design

Morgantown, West Virginia
2014

Keywords: Gustave Courbet, Venus and Psyche, Mythology, Realism, Second Empire Copyright 2014 Amanda M. Guggenbiller 


\section{ABSTRACT \\ Compositions of Criticism: A Reinterpretation of Gustave Courbet's Paintings of Nudes}

\section{Amanda M. Guggenbiller}

This paper investigates the mythological paintings created by Gustave Courbet (18191877) in the nineteenth-century, and their connection to Courbet's relationship with the political regime of the French Second Empire. In 1862, Courbet began three variations of one painting, originally titled Study of Women, and shortly after changed to Venus in Jealous Pursuit of Psyche. The mythological context of the paintings was commonly represented in the arts, although the scene Courbet depicted was unusual, and unlike any other. The principles upon which Courbet created his art, which also shaped the concept of Realism, the movement which Courbet started, strongly opposed all representations of fictional or artificial imagery, including mythology, quite the opposite of this scene of goddess and mortal. Given the strict regulations of censorship during the period, the difficult relationship between Courbet and the administration of Napoleon III, and the predilection of the artist for being arrogant and recalcitrant, it seems unlikely that the artist would conform to parameters regarding his art set by a government that he opposed.

Shortly after Courbet's death in 1877, an effort was made to de-politicize the artist's paintings, stripping them of their political and critical connotations and presenting them as purely aesthetic works. Recent scholarship has strayed from this understanding in an effort to discover the artist's embedded political and social criticism. While a number of Courbet's paintings have been reinterpreted as such, little investigation has been completed to reimagine Courbet's erotic nudes as carrying political and social commentary. Through research into the artist's method of employing models, Proudhonian philosophical theories, the social-historical context of the lesbian and homosexuality in the nineteenth-century, and iconography within his paintings, this thesis will provide a reinterpretation of Courbet's paintings of nudes from carnal to critical, and aims to provide a consideration for reinterpretation of the artist's works from aesthetic to allegorical. 


\section{CONTENTS}

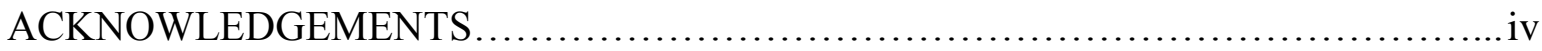

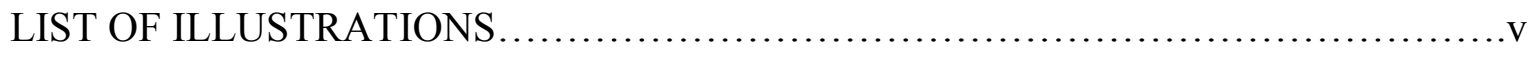

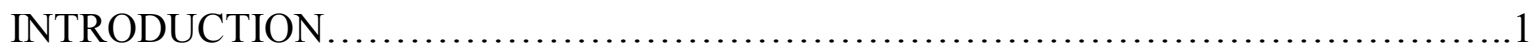

CHAPTER ONE: Courbet's History......................................... 11

CHAPTER TWO: Sexuality within Courbet's Paintings.......................... 18

CHAPTER THREE: Philosophical Influence........................................28

CHAPTER FOUR: The Second Empire and Courbet.................................. 32

CHAPTER FIVE: Venus and Psyche ........................................... 44

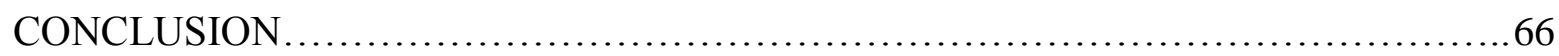

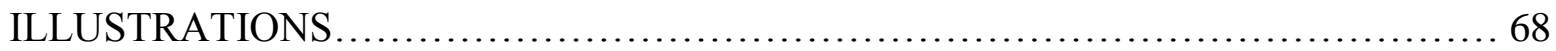

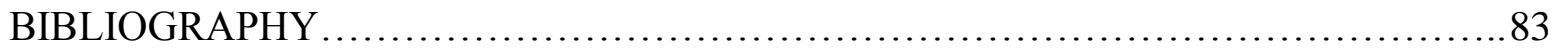




\section{ACKNOWLEDGEMENTS}

This Master's thesis would not have been possible without the guidance and encouragement from my graduate committee: Dr. Rhonda Reymond, Dr. Janet Snyder and Dr. J. Bernard Schultz from the College of Creative Arts at West Virginia University. I will be forever grateful for your patience, edits, and recommendations over the years. My unconventional educational path and decision to begin a career while finishing my thesis was difficult at times, but you all were unbelievably accommodating and your support was uplifting.

I would like to give special thanks to my family and my friends, especially Maureen Murphy, who read countless versions of my thesis and always provided her critiques and encouragements. Thank you to the staff at the Art Museum of WVU: Dr. Joyce Ice, Valerie M. Wright, and Robert Bridges, for always checking up on me and asking for progress reports during staff meetings. To my best friend and my husband, Dr. Samuel Bates, thank you for your support, tolerance and encouragement. Many museum trips to many different cities would not have been possible without you. 


\section{ILLUSTRATIONS}

Figure

1. Honoré Daumier, Ratapoil, c. 1851, Musée d'Orsay, Paris

2. Gustave Courbet, Burial at Ornans, 1849-1850, Musée d'Orsay, Paris

3. Gustave Courbet, The Wheat Sifters, 1853-1854, Musée des Beaux-Arts de Nantes

4. Gustave Courbet, Detail of The Artist's Studio, 1849-1850, Musée d'Orsay, Paris

5. Julien Vallou de Villeneuve, Nude Study, registered 1853, Bibliothèque Nationale de France, Paris

6. Gustave Courbet, The Bathers, 1853, Musée Fabre, Montpellier

7. Gustave Courbet, Woman with a Parrot, 1866, Metropolitan Museum of Art, New York

8. Julien Vallou de Villeneuve, Standing Nude, registered 1853, Bibliothèque Nationale de France, Paris and detail of Gustave Courbet, The Bathers, 1853, Musée Fabre, Montpellier

9. Gustave Courbet, Jo, La Belle Irlandaise, 1856-1866, Metropolitan Museum of Art, New York

10. Gustave Courbet, The Sleepers, 1866, Petit Palais, Paris

11. Julien Vallou de Villeneuve, Reclining Nude, registered 1853, Metropolitan Museum of Art, New York

12. Peter Paul Rubens, Venus and Adonis, c. 1635, Metropolitan Museum of Art, New York

13. Gustave Courbet Young Ladies on the Banks of the Seine, 1857, Petit Palais, Paris

14. Gustave Courbet, Return from the Conference, 1863, unknown

15. Gustave Courbet, The Artist's Studio, a real allegory summing up seven years of my artistic and moral life, 1854-1855, Musée d'Orsay, Paris

16. Gustave Courbet, Study of Women (Venus and Psyche), 1864, unknown

17. Gustave Courbet, The Awakening (originally titled Venus and Psyche), 1864, unknown 
18. Gustave Courbet, Venus and Psyche, 1866, Kunstmuseum, Bern, Switzerland

19. Alexander Cabanel, The Birth of Venus, 1863, Musée d'Orsay, Paris

20. Achielle Devéria, Les petits jeux innocens, Les gages tires, n.d., location unknown

21. Achielle Devéria, The Girl Friends Discovered, c. 1837, lithograph, Musées Nationaux, Paris

22. Gustave Courbet, Woman with White Stockings, 1864, oil on canvas, The Barnes Foundation, Philadelphia

23. Gustave Courbet, Reclining Nude, 1862, oil on canvas, private collection

23. Antonio Canova, Psyche Revived by Cupid's Kiss, 1793, marble, Musée du Louvre, Paris

25. François Gérard's Psyche Receiving Cupid's First Kiss, 1798, oil on canvas Musée du Louvre, Paris

26. Jacques-Louis David, Cupid and Psyche, 1817, Cleveland Museum of Art, Ohio

27. François Picot, Cupid and Psyche, c. 1817, Musée du Louvre, Paris

28. Reconstruction of Gustave Courbet, Cemetery at Solferino, n.d.

29. Reconstruction of Gustave Courbet, Woman Kneading, n.d.

30. Tudor Rose brooch of Mathilde Bonaparte

31. Portrait of Mathilde Bonaparte, n.d. 


\section{Introduction}

I have studied the art of the ancients and the art of the moderns, avoiding any preconceived system and without prejudice. I no longer wanted to imitate the one than to copy the other; nor, furthermore, was it my intention to attain the trivial goal of "art for art's sake". No!... To be in a position to translate the customs, the ideas, the appearance of my time, according to my own estimation; to be not only a painter, but a man as well; in short, to create living art - this is my goal. - Gustave Courbet, The Realist Manifesto, 1855

In a large, quiet gallery at the Kunstmuseum in the capital city of Switzerland, displayed with a number of other nineteenth-century artworks, is a painting by Gustave Courbet, 18191877, titled Venus and Psyche. This mythological painting, completed in 1866, differs from his usual body of work - scenes of serene landscapes, portraits of his family and acquaintances, large-scale paintings of contemporary people in realistic settings. Depictions of this tale of love are often represented in the arts, with the figures of Cupid and Psyche, not Psyche and her lover's jealous mother, Venus. Courbet often used the same models for his paintings, but these figures in the Venus and Psyche paintings do not appear to be seen throughout any of Courbet's other paintings. Who are these women, and why did Courbet choose to represent this specific scene of voyeurism and desire? As an artist, who frequently rebelled against authority and government, he was known for his arrogance and outspokenness. With his most popular works today being those in which he criticized individuals, and social and political organizations, surely there must be a reason why Courbet would have chosen to portray a traditional mythological scene.

The late eighteenth and nineteenth centuries of France were subject to great political censorship of the arts. Occurring mainly during the reign of Napoleon Bonaparte, and during the reign thirty-three years later of his nephew, Napoleon III, the government strictly supervised art that was created and displayed publically. Newspapers, theaters, writers, and visual artists were 
all subjected to rules and regulations, with punishments and even imprisonment imposed on some individuals who rebelled. ${ }^{1}$ This policing of artistic expression was tolerated by some, but for others it provided a challenge; an opportunity to express their work in a veiled way that would fall within the guidelines of what was found to be appropriate yet illustrate their negative commentary. The caricatures created by Honoré Daumier may have been the most notable and memorable from the nineteenth-century, but criticism of the government through art was not limited strictly to caricatures. French Realist artist Gustave Courbet also took part in this defiance, albeit slightly more covertly than the caricature artists of his time, relying on the guise of mythological and ambiguous titles and religious subjects to express his distaste for the government. This criticism can be examined in his Venus and Psyche paintings, three works completed between 1864 and 1866, which display two sexually suggestive nude female figures in a bedroom setting.

The research of Petra ten-Doesschate Chu has been significant to the study of Courbet and was most instrumental to my own investigation of Courbet's mythologically titled paintings. Chu's article, "Gustave Courbet's Venus and Psyche: Uneasy Nudity in Second-Empire France," introduced the concept of Courbet representing political or social ideas through his paintings of nudes. This thesis argues for a reinterpretation of Courbet's paintings of nudes, an idea derived from Chu'd article, but expanded to a broader scope, including all his paintings of erotic nudes. Chu raises the important question concerning why Courbet's Venus and Psyche was considered improper and was banned from the 1864 Salon, while Alexandre Cabanel and Paul-JacquesAimé Baudry's Venuses were celebrated. To understand this, Chu describes the social-historical context of prostitution at that time in great detail.

\footnotetext{
${ }^{1}$ Robert Justin Goldstein, "Fighting French Censorship, 1815-1881,” The French Review, vol. 71, no. 5, (April 1998): 787-788.
} 
During the mid-nineteenth century, the concept of pornography had not been defined, but images of indecent and improper subject matter were known, many of which represented prostitutes. $^{2}$ The changing environment in which services were rendered and the varying social classes of the clientele made up the structure of the hierarchy of this occupation. This class system of "working women" emphasized the lenience that nineteenth-century society had with prostitution. Tolerance of these relationships was in fact surprisingly high; however, this may have been due to the commonly known indiscretions of Napoleon III, some of which were with known courtesans. ${ }^{3}$ Chu explains that the setting of the Venus and Psyche paintings suggests a brothel interior, where prostitutes were often alleged to take part in homosexual relations, perhaps sparking the scandal regarding this painting. ${ }^{4}$

Chu includes an excerpt from Pierre-Joseph Proudhon's Du Principe de l'art et de sa destination sociale, 1865, which describes Venus and Psyche as having a moral tone that was aimed at criticizing the government. From this excerpt, Chu argues that Proudhon, a French philosopher and friend of Courbet's, was more influential in the creation of this painting than previously believed. ${ }^{5}$ Proudhon supported the artist's depiction, which followed opinions expressed in his philosophic writings at the time about women and family, suggesting that perhaps Proudhon had a hand in the concept of the painting. ${ }^{6}$ Proudhon's writings focused on a

\footnotetext{
${ }^{2}$ Griselda Pollock, Vision and Difference: Femininity, Feminism and Histories of Art, (London: Routledge, 1988), 130.

${ }^{3}$ Perhaps his most well-known affair was one that he carried on with a famous courtesan, Harriet Howard. Their relationship appeared to be more than just a sexual relationship in that she publicly financed his return to France in 1848. John Bierman, Napoleon III and His Carnival Empire (New York: St. Martin's Press, 1988), 54-57.

${ }^{4}$ Petra ten-Doesschate Chu, "Gustave Courbet's Venus and Psyche: Uneasy Nudity in Second-Empire France," Art Journal vol. 51, no. 1 (Spring 1992): 41.

${ }^{5}$ The majority of scholarship agrees that the relationship between Courbet and Proudhon was close and strongly links the two together, although some recent research does debate this idea. Richard Vincent O'Connell is an example of a recent source who argues that Courbet and Proudhon were distant acquaintances than close friends. For more on this, see the thesis of Richard Vincent O'Connell, "Art at the Barricades: Courbet and Proudhon, The Trajectory of an Asymmetrical Relationship," (Masters thesis, University of Colorado, 2011).

${ }^{6} \mathrm{Chu}$, "Uneasy Nudity," 42.
} 
woman's place in the home and argued that any refusal to accept this domestic life equated them with prostitutes. Venus and Psyche and the pendant piece, Woman Kneading, which was never completed, are paintings that are visual representations of the philosopher's ideas of the categorization of women into two polar-opposite roles. ${ }^{7}$ This companion piece depicted a woman in a kitchen, fulfilling her duties and role as a homemaker, with children surrounding her. Paired with the Venus work, these two paintings represent the two avenues a woman can choose for her life; what Proudhon considered to be the ideal life and the corrupt life, according to Proudhonian theories. The two paintings serve as metaphors for republicanism and imperialism, and attack the regime of Napoleon III for its corruption and demoralization. ${ }^{8}$

The letters of Gustave Courbet are another significant resource that has shaped the construction of this thesis. Translated by Chu in 1992, these letters provide insight not possible in other forms of documentation. This source has been indispensable to my research, as it presents access to the thoughts and opinions of the artist while he created Venus and Psyche, and what these works reference in regard to the personal belief and events occurring during Courbet's life. The recipients of the letters range from his family and close acquaintances, to newspaper and magazine editors, to government officials, but each letter provides a point of view from the artist himself.

The notion that Courbet painted works that were attacks against the government is an idea that is shared by other art historians besides Chu. Steven Z. Levine's "Courbet, Bronzino and Blasphemy," which was published less than a year before Chu's 1992 article, shares this belief, although his supporting argument differs. Levine claims that Courbet's Burial at Ornans, 1850 , is an allegorical representation in which he depicted religion, sexuality, and

\footnotetext{
${ }^{7}$ Chu, "Uneasy Nudity," 42.

${ }^{8}$ Chu, "Uneasy Nudity," 42.
} 
politics in an iconographical and formal manner that references historical paintings while displaying a contemporary scene. This painting has long been seen as having allegorical ties, however, Levine's interpretation of the content is original. Citing Italian Mannerist painter Bronzino, 1503-1572, as the inspiration for Burial at Ornans, Levine claims that Courbet was creating a painting that appeared to the common viewer to be a realistic depiction of a common locale, however, the work actually references Bronzino's Deposition, while tying in suggestions of contemporary politics. ${ }^{9}$

Levine believes that in order for an artist to break away from the preceding artistic constraints, one needs to demystify history, a theory that also followed the praxis of Courbet's contemporaries, Karl Marx and Pierre-Joseph Proudhon. ${ }^{10}$ "Courbet's strategy was decisively to differentiate his revolutionary images over and against the iconological and formal traces of what was in his time the canonical, and hence inescapable, art of the past." ${ }^{11}$ Levine finds several connections between Courbet's and Bronzino's paintings, and suggests that not only was the Deposition a painting that Courbet cited within his work, but that there were other religious paintings by Bronzino that were reference points for the Realist artist. While this argument is well supported, for the purpose of this paper it is not necessary to advocate for or against Levine's claims, but it is important to note other Courbet scholars support the view that the artist used his paintings to convey his sentiments regarding contemporary politics.

\footnotetext{
9 The strongest argument of Levine's is that Courbet's Burial at Ornans to Bronzino's Deposition of Christ, 15401545. The initial location of the Bronzino painting was within the Palazzo Vecchio in Florence, but in 1555 the oil painting was moved to the Musée des Beaux-Arts in Besançon, Courbet's hometown. For more, see Steven Z. Levine, "Courbet, Bronzino and Blasphemy," New Literary History, vo. 22, no. 3, (Summer, 1991): 677-714.

${ }^{10}$ Levine, 685.

${ }^{11}$ Levine, 677.
} 
The life and artwork of Gustave Courbet, the founder of Realism and self-proclaimed "proudest and most arrogant man in France," has fascinated academics for years. ${ }^{12}$ His depictions of contemporary social issues, such as The Stonebreakers, 1849, Burial at Ornans, 1849-1850, and The Artist's Studio: A Real Allegory Summarizing A Period of Seven Years of My Life as an Artist, 1854-1855, make his notoriety and impact on nineteenth-century French art hard to deny. Much has been written about the artist, both about his paintings and his personal life, including the political events that led to his exile from France in $1871 .{ }^{13}$ While there has been some discussion regarding a connection between Courbet's political stance and the impact this had on his paintings, little has been written that considers the significant impact that French politics and the Second Empire administration had on his works that were not as blatantly satirical or political. ${ }^{14}$

Beginning in the 1850 's, Courbet became fascinated with painting the nude female figure, a canonical art historical subject. His experience with illustrating the female figure was not vast; however, a general understanding of the human body is necessary for any artist who wishes to include figures within their work. The women Courbet depicted were not the idealized depictions of women most often seen in art, but rather scandalous portrayals that reflected women in contemporary times. Analyses of these paintings in this thesis, including The Sleepers and Woman with a Parrot, both completed in 1866, and three Venus and Psyche paintings created between 1864 and 1866, identify the overt sexual representations that are displayed in these works. The Sleepers portrays two women, entwined in a sensual embrace, in what would

\footnotetext{
${ }^{12}$ Gustave Courbet, Letters of Gustave Courbet, ed. and trans. Petra ten-Doesschate Chu, (Chicago: University of Chicago Press, 1992), 116.

${ }^{13}$ Gerstle Mack, Gustave Courbet, (New York: Alfred A. Knopf, 1951) 249-359.

${ }^{14}$ The majority of texts about Courbet discuss his political motives and satirical paintings in some form, however, Fried's analysis discuss a variety of Courbet's paintings that are usually not associated with allegorical connotations, which Fried argues to contain social and political commentary on issues during the nineteenth-century. Michael Fried, Courbet's Realism, (Chicago: University of Chicago Press, 1985), 148-188.
} 
commonly be described through the male heterosexual lens as a representation of lesbianism. How this painting differs from Courbet's Venus and Psyche paintings in terms of its sexual representation is the absence of any mythological context, bringing forward the erotic and homosexual tones of the work. ${ }^{15}$ The illustration of suggested homosexuality is evident not only in this work, but at least in two others. This depiction of lesbianism is the most widely discussed aspect of The Sleepers, and is also apparent within a majority of his nude paintings. While Courbet's representations of lesbianism and sexuality cannot be ignored, should we believe that displaying eroticism was the only motivation for Courbet to produce such controversial paintings? Since it has been argued that Courbet utilized double-meanings within his paintings, it would be plausible that an allegorical approach could be seen throughout his oeuvre and not limited to his paintings directly depicting social issues. Michael Fried argues in Courbet's Realism, that many of the artist's paintings that are typically thought of as his basic depictions in the Realist style are, in fact, allegories themselves. ${ }^{16}$

The most obvious representation of an allegory in Courbet's work would be the 18541855 painting The Artist's Studio: A Real Allegory Summarizing A Period of Seven Years of My Life as an Artist. To the nineteenth-century viewer, the painting provided portraits of many wellknown persons. In the center of the work is a self-portrait of the artist, seen in the act of painting a landscape. ${ }^{17}$ The figures that flank the central point of this large scale painting are divided into two groups, with the identification of the majority of the figures decoded by Hélène Toussaint in the exhibition catalogue that accompanied the landmark exhibition of 1977 at the Petit Palais in

\footnotetext{
${ }^{15}$ Maura Reilly, "La Vice à la Mode: Gustave Courbet and the Vogue for Lesbianism in Second Empire France," (PhD diss., New York University, 2000), 196-198.

${ }^{16}$ Fried, 148-188.

${ }^{17}$ It is speculated that the two figures closest to Courbet are allegories themselves, the nude female standing behind Courbet representing Truth and the young boy beside him representing Innocence. John F. Moffitt, "Art and Politics: The Underlying Pictorial - Political Topos in Courbet's "Real Allegory"," Artibus et Historiae, vol. 8, no. 15 (1987): 184.
} 
Paris. ${ }^{18}$ In an undated letter to Champfleury, Courbet mentioned that the right side consisted of "all the shareholders, that is, friends, workers, and art lovers," and the left side was composed of "the other worlds of ordinary life, the people, misery, poverty, riches, the exploited, the exploiters, those who live on death." ${ }^{19}$ One of the figures on the left side of the painting, the seated man with two dogs at his lap, has been identified as Napoleon III, the pointed mustache of the ruler the indicator of his identity in many other paintings and caricatures. Viewers would have made an association between Courbet's figure of the man with a pointed mustache and the character Ratapoil, who was created by Honoré Daumier in 1850. Ratapoil was the central figure in many of Daumier's lithographs and sculptures, the character based upon Napoleon III and his signature facial features (fig. 1). ${ }^{20}$ This identification of Napoleon III and other governmental officials in Courbet's painting, and their inclusion in this particular section of the painting communicates the negative feelings that the artist had toward the Second Empire government, as well as proof that the artist occasionally used actual portraiture of people within his paintings in place of models.

As in The Artist's Studio, Courbet's depicted portraits of real figures within the townsfolk at his earlier Burial at Ornans. ${ }^{21}$ He combined portraits of some of the people in Ornans with generalized representations of figures, just as he did in The Artist's Studio. As with The Artist's

\footnotetext{
18 ) Linda Nochlin, "Courbet's Real Allegory: Rereading The Painter's Studio," in Courbet Reconsidered, ed. Sarah Faunce and Linda Nochlin (New Haven: Yale University Press, 1988) 17-43. There has been a significant amount published regarding the identification and iconography within this painting. For a more in-depth examination of this particular work, see Hélène Toussaint et al., Gustave Courbet: 1819-1877: [an exhibition organized by the Réunion des musées nationaux], at the Royal Academy of Arts, 19 January-19 March 1978, (London: Arts Council of Great Britain, 1978.

${ }^{19}$ Fried, 157. Fried's translation is taken from Toussaint's exhibition catalogue that includes this letter from Champfleury.

${ }^{20}$ Daumier's Ratapoil, meaning skinned rat, was based off of the actual personality of Napoleon III, prior to his coup d'état in December 1851. After Napoleon III came into office, public censorship because prominent and images of Ratapoil were severely curbed. Albert Boime, "The Second Empire's Official Realism," Art in an Age of Civil Struggle, 1848-1871, (Chicago: University of Chicago Press, 2007), 585-588.

${ }^{21}$ Mack, 77-80.
} 
Studio, and also signified in the title of the work, this blend of imagined figures with realistic people helped present the painting as a 'real allegory'; one person has even called it "a visual paradox, just as its title is a verbal paradox." 22 This interesting mix of figures raises the question, did Courbet employed this method on all his paintings. Examining this question provides a new angle from which to consider his paintings and suggests a closer reading is needed into figures who have not yet been identified as model or specific individuals. In some cases, the identification of the figures within the paintings would be visible only to a certain group; for example, the figures in Burial at Ornans would only be identified by those who lived in the town, which would then provide a different context and meaning of the work for those who recognized those individuals than for the Parisians who perhaps saw fictitious people. In the case of The Artist's Studio, the identification of some individuals would have been broader, since the figures Courbet chose to portray well-known throughout the city, and perhaps the country, so the allegorical view on this work would vary from person to person, perhaps providing Courbet with the security to create such critical paintings.

While this veiled criticism of the government has been noted by historians in the past, the argument that has not yet been explored in depth is if the same shrouded condemnation was also a sentiment expressed through Courbet's nudes. This thesis will investigate the notion that not only were Courbet's nude paintings expressing homosexual acts, but also that they convey his political perspective and criticism of the government. By creating earlier allegorical paintings, such as The Artist's Studio, Courbet established a precedent of communicating with the viewers in this form. Whether due to fear of the repercussions of an overt illustration, or the understanding that in order for these paintings to be received in exhibitions it would be necessary to camouflage the true meaning of his works, Courbet was aware that any obvious political

\footnotetext{
${ }^{22}$ Mack, 131.
} 
denunciation would be censored and rejected from any public forum, and might include possible public punishment. The artist's decision to covertly express his opinion under the guise of artwork displaying history or mythology, such as the Venus and Psyche paintings, provided Courbet with a channel to communicate with the public. 


\section{I: Courbet's History}

Throughout his artistic career, Gustave Courbet frequently interacted with Second Empire regime and Napoleon III. ${ }^{23}$ Beginning in 1841 and lasting through to Courbet's death in 1877, the rapport between artist and government was turbulent. The cordial relationship that began with Courbet's initial acceptance into the Salon of 1848 diminished within a matter of years. Shortly before the 1855 Exposition Universelle, Courbet was requested not to submit artwork to the exhibition that did not favor the administration. Irate at having three works refused from this exhibit, and in a show of opposition to the earlier request, Courbet then set up a rival exhibition; a retrospective of his own work next to the venue of the Exposition Universelle. After many public quarrels with political figures, Courbet's association with the French government ended, and his involvement in the destruction of the Vendome Column lead to his self-imposed exile from France in 1873. This relationship between Courbet and the government was heavily influenced by the artist's Republican upbringing and anti-authoritative stance, which was a characteristic of Courbet's personality from early on in his life and shaped his views on the government.

Courbet's aversion of authority was not a sentiment that developed in his adult life, but was an attitude that began with the adversarial relationship between the artist and his father. The relationship between Courbet and his father, Regis Courbet, 1798-1885, has been well documented in Gerstle Mack's biography of the artist and additionally in the letters from Courbet to his family, which document the quarrels between the father and son. ${ }^{24}$ The Courbet family was native to the Franche-Comté area of France and while they were a farming family, they had inherited the large amount of land amassed by their ancestors. Much of this land was given to

\footnotetext{
${ }^{23}$ Louis-Napoleon renamed himself Napoleon III in honor of his uncle, Napoleon I.

${ }^{24}$ Mack, 14-18.
} 
Courbet's maternal grandfather, Jean-Antoine Oudot, 1767-1848, after his service during the French Revolution. Oudot was a staunch Republican and was awarded this land in 1793 because of his support of the Jacobins. ${ }^{25}$ Courbet had a close relationship with Oudot, from his childhood into early adulthood, and some theories speculate that the painting Burial at Ornans, (fig. 2) was in part a tribute from the artist to his recently deceased grandfather. ${ }^{26}$ Within the crowd that surrounds the grave, many friends of Oudot have been identified, indicating that the painting is depicting Oudot's burial, however, Courbet also inserted a portrait of his grandfather as one of the bystanders. ${ }^{27}$ Albert Boime argues that Courbet's connection to the first French revolution, by means of his grandfather, is what made his artistic personality unique. ${ }^{28}$ The commonalities between the two men, with their similar personalities and Republican beliefs, could have provided the impetus for Courbet to produce such powerful paintings. The paintings Courbet created emphasized the undesirable and destructive actions of the ruling political party, criticisms that were shared by Republicans.

From an early age, Courbet grappled with powerful and authoritative figures. During his younger years, he was reprimanded by his teachers, clergymen and family for his disobedient behavior. $^{29}$ One story is of a young Gustave declaring such numerous and excessive sins during confession that the clerics refused to grant him absolution. ${ }^{30}$ It was only after the Cardinal was made aware of this situation that he requested the young boy come see him so he could witness

\footnotetext{
${ }^{25}$ Boime, Art in the Age of Civil Struggle, 140. Courbet's paternal grandfather, Claude-Louis Courbet, also had contributed to the land that the artist's family had owned as he profited from the sale of estates, sold to him by French refugees or non-republicans during the revolution.

${ }^{26}$ Dominique de Font-Réaulx, Gustave Courbet, (New York: Metropolitan Museum of Art, 2008), 174-175.

${ }^{27}$ James C. McCarthy, "Courbet's Ideological Contradictions and the Burial at Ornans," Art Journal, 35, no. 1 (Autumn, 1975), 14. Courbet wrote to Champfleury "these have already posed...the dead man and his pallbearers...," indicating that a portrait of the deceased himself was included within the painting. A portrait previously done of Oudot in 1844 matches the depiction of a figure within the Burial painting. Mack, 773.

${ }^{28}$ Boime, Art in the Age of Civil Struggle, 139.

${ }^{29}$ Mack, $10-13$.

${ }^{30}$ Mack, 12.
} 
for himself the indulgences that Courbet claimed to have committed. After convincing the boy to confess his sins:

Suddenly the cardinal, who had been looking in another direction, turned his head quickly, and saw that the boy was reading from a huge notebook. In order to be sure that he would forget nothing, Courbet had compiled a list of all the sins it would have been possible for anyone to commit, from the most trifling peccadillo to the blackest of crimes. It was this litany he had read to his other confessors, who had failed to perceive the fraud in the darkness of the confessional. ${ }^{31}$

This rebellious and rowdy attitude that he possessed as a young boy towards authority and the church continued throughout his life.

His first introduction to art was sometime after 1833, when he received elementary drawing lessons from a teacher named Baud, whom he often called le père. ${ }^{32}$ Baud was a pupil of Antoine-Jean Gros, 1771-1835, a well-known neoclassical painter who had been a student of Jacques-Louis David, 1748-1825. ${ }^{33}$ After his studies in Ornans were completed in 1837, Courbet was sent to Besançon by his father, Regis, who intended for his son study law at the Collège Royale. Countless letters document the young artist's hatred of the schooling and accommodations at Besançon, and he often threatened to run away from the school. ${ }^{34}$ At Besançon, Courbet was mentored by another David follower, director of the school, Charles Flajoulot. ${ }^{35}$ After much persistence, Regis finally allowed his only son to move to Paris to pursue his career in art. In November 1840, Courbet set his sights on Paris and thus began his long career in the French capital. ${ }^{36}$

\footnotetext{
${ }^{31}$ Mack, 12.

${ }^{32}$ Mack, 13.

${ }^{33}$ Mack, 13. This is the first of many interactions that Courbet would have with artists who had trained with David. Along with Gros, Charles Flajoulet, 1774-1840, was another artist who studied under David and assisted Courbet in learning the basics of art. Ingres, another student of David, and Delacroix, who was taught in the Neoclassical style of David, were contemporaries of Courbet, fellow Salon exhibitors, and former jury members. Mack 19.

${ }^{34}$ Mack, 13-18.

${ }^{35}$ Mack, 19.

${ }^{36}$ Mack, 23.
} 
Courbet arrived in Paris at the age of twenty but worked for several years before receiving any recognition for his artistic talents. His former headmaster and mother's cousin, Abbé Oudot, lived in Paris and urged Courbet to join an art school which was headed by Charles von Steuben, $1788-1856 .{ }^{37}$ Rebelling against educational institutions and authority, much like in the past, Courbet refused to join the school, but would informally visit the studio of von Steuben. Courbet preferred to work in more relaxed and informal studios, and he spent some time at the Atelier Suisse. Run by a formal model by the name of Suisse, he provided art students a place to draw and paint nude models for a nominal fee. ${ }^{38}$ The Atelier Suisse was popular amongst many artists, including Eugène Delacroix, and later Impressionist artists such as Camille Pissarro and Paul Cézanne. Courbet must have felt quite close to the owner as he painted a portrait of Suisse in 1861 titled Monsieur Suisse. ${ }^{39}$ Along with these two studios, Courbet was also associated with Auguste Hesse, 1795-1869, the head of a school of painting. Courbet developed a relationship with the instructor and would often go to him to seek his advice. At one point Hesse was even listed as Courbet's instructor for the Salon of 1844, but Courbet vehemently denied he was a student of Hesse's. In order to submit a work to the Salon, the name of an instructor was required on all submissions from new applicants, and Hesse was kind enough to lend his name to Courbet's work. ${ }^{40}$

I find myself listed in this year's Salon catalog as a student of M. Auguste Hesse. To tell the truth, I must declare that I have never had a teacher. The administration's error arises, no doubt, from a practice that in recent years has become common: painters, especially those just starting out, believe it to be necessary, in order to be admitted to those exhibitions, to present themselves

\footnotetext{
${ }^{37}$ Mack, 26-27.

${ }^{38}$ Mack, 27-31.

${ }^{39}$ Fernier, Robert, La Vie et l'ouvre de Gustave Courbet: catalogue raisonné, (Genève: Fondation Wildenstein, 1978), 176.

${ }^{40}$ Courbet, Letters, 101.
} 
under the official patronage of a well-known name in the arts. That pure

formality has been turned into a joke... ${ }^{41}$

Shunning academic training, Courbet opted to receive his education informally and spent much time copying works in the galleries of the Louvre. Shortly before Courbet moved to Paris, Napoleon III amassed a large collection of Spanish art and opened the Galerie Espagnole (Spanish Gallery) in the Louvre in 1838; many works by Diego Velázquez and Francisco Zurbarán were included in this collection. ${ }^{42}$ In addition to Spanish artists, Courbet favored the Venetian, Dutch and Flemish masters, such as Paolo Veronese, Rembrandt van Rijn, and Anthony Van Dyck, and in part from their works, the young Frenchman began to learn the art of painting. ${ }^{43}$

Courbet's first painting submitted to the French Salon was in 1844, Self-Portrait with the Black Dog. Hesse convinced Courbet to submit the work along with a newer piece that was unfinished and was later rejected from the Salon. ${ }^{44}$ Regardless of his rejection, Courbet was still elated with the opportunity to have one work in the exhibition. ${ }^{45}$ After this first acceptance, Courbet became a frequent exhibitor at the Salons for the next twenty-five years. The caliber of the work that Courbet had created at such a young age, and the fact that his paintings were consistently accepted, signified that the artist was knowledgeable about the Salon juries, the public and their taste in what was deemed acceptable art.

\footnotetext{
${ }^{41}$ Courbet, Letters, 101.

${ }^{42}$ Erich Lessing and Vincent Pomarède, The Louvre: All the Paintings (New York: Black Dog \& Leventhal Publishers, 2011), 709-11.

${ }^{43}$ Mack, 31.

${ }^{44}$ Mack, 35.

${ }^{45}$ Courbet, Letters, 46. In a March 1844 letter to his family he wrote, "I have finally been accepted to the Exhibition, which gives me the greatest pleasure. It is not the paintings that I would have most wanted to have accepted, but it is no matter, this is all I ask, for the painting that they refused was not finished...The painting that was accepted is my Portrait with landscape background. Everyone compliments me on it. The funny thing is that it was painted two or three years ago, for my black dog is in it, by me."
} 
Although Courbet was vocal about his opinions of the French government and politics, it was his participation in the destruction of the Vendome Column in 1871 led to his exile from France. During the Paris Commune, Courbet proposed that the column, a monument located in the heart of Paris, be demolished due to its immortalization of past conquests and war, and idolization of historical dynasties, specifically that of Napoleon I. The column was built in the early 1800's, modeled after Trajan's Column in Rome, and decorated with scenes from Napoleon I's victory at the Battle of Austerlitz, topped with a statue of the former ruler. While Courbet had no physical connection to the destruction of the column, he had written a letter in September 1870 to the Government of National Defense in which he suggested dismantling the column. ${ }^{46}$ The public became aware of this suggestion and proceeded to destroy the column, and Courbet was held responsible for their actions, despite his assertions that he did not request the Vendome Column be destroyed. ${ }^{47}$ Courbet was ordered to fund the rebuilding of the monument, which exhausted much of his fortune and forced him to flee to Switzerland for a selfimposed exile in order to escape bankruptcy. The French government seized many of his paintings and property, and placed much of his family under surveillance, the stress and grief of which Courbet claimed killed his sister Zélie in May $1875 .{ }^{48}$ Courbet was eventually granted amnesty in France, but remained in Switzerland, where he died on December 31, 1877, shortly after the public sale of his studio and belongings in Paris, and the day before he was to begin payments for the rebuilding of the Vendome Column. ${ }^{49}$

After his death, there was a significant attempt made to rehabilitate the public image of Courbet following his participation in the destruction of the Column. Art critic Jules Castagnary,

\footnotetext{
${ }^{46}$ Courbet, Letters, 388. This draft of a letter to the Government of National Defense is dated September $14,1870$.

${ }^{47}$ Courbet, Letters, 392. In a letter to the Government of National Defense dated October 5, 1870, Courbet wrote "Some fools pretend not to have understood my letter. I did not request that the Vendome Column be broken."

${ }^{48}$ Mack, 345-347.

${ }^{49}$ Mack, 355-356.
} 
1830-1888, who befriended Courbet in 1860, advocated for the restoration of Courbet's artistic career. His efforts culminated in the inclusion of eleven of Courbet's paintings in the Great Centennial Exhibition of One Hundred Years of French Art at the Paris World's Fair of 1889, which also celebrated the hundredth anniversary of the French Revolution. ${ }^{50}$ This exhibition emphasized Courbet's artwork, but avoided any political connections, and steered the public away from his well-documented involvement with the Column; instead it defined his status as an artist whose work rivaled that of his French contemporaries and predecessors. ${ }^{51}$ The rehabilitation of Courbet's image and paintings during this time, straying away from political notions in his paintings, could be the reason why Courbet's erotic paintings are viewed as sexual and not as critical. With the notions of criticism stripped away and forgotten about for the purpose of recovering his reputation, these paintings are seen to the twenty-first century viewer only as aesthetic and sensual. Discounting the artist as a figure with political ties or theories so soon after his death might also have led to the disregard of Courbet's transparently political or allegorical paintings, and his covert ones, such as his nudes including Venus and Psyche, as a criticism of the former administration. Paintings that exhibit a more overt tone of political or social criticism, such as Burial at Ornans or Return from the Conference, could easily be redefined, whereas his nude paintings would be less problematic to redefine as simply nude figures with no allegorical themes.

\footnotetext{
${ }^{50}$ Linda Nochlin, "The De-Politicization of Gustave Courbet: Transformation and Rehabilitation under the Third Republic," October, vol. 22, (Autumn, 1982): 66. Courbet's family and the French government also assisted and organized his pieces to be included in this exhibition, the president of the Republic even approved of this decision. ${ }^{51}$ Linda Nochlin's 1982 article thoroughly discusses the ways in which Castagnary and Paul Mantz, writer for the Gazette des Beaux Arts, reoriented the perception of Courbet from political agitator to painter.
} 


\section{II: Sexuality within Courbet's Paintings}

Recognizing the progression of an artist's style and manner is important in order to comprehend the choices made within a work of art. In the case of Courbet, the overtly sexual tones found in some of his paintings indicate a transformation in the artist's work from his former controversial realistic paintings of social scenes, to immoral and lewd representations of women. This chapter investigates the beginning of his fascination with the nude and the artist's change from the standard depictions of nude figures to lascivious portrayals of women deemed inappropriate for public display.

The invention of the daguerreotype in 1839 transformed the use of models for art, with the method of employing photographs to work from wide spread amongst artists, including Courbet. The use of photographs of models, clothed or nude, was revolutionary for artists. No longer was it necessary to have a model sit for hours in their studio; instead, a photograph could be made of the model in the pose requested. It is not known if Courbet made photographs himself, but there is significant evidence that supports his use photographs in the creation of some paintings.

Julien Vallou de Villeneuve, 1795-1866, was a French artist who is most well-known for his photographs of nudes, which were created for artists to use in place of sitting models. Many of the photographs from Vallou de Villeneuve bear a striking resemblance to the poses and outlines of the figures in several Courbet paintings, such as The Bathers and Woman with a Parrot. Courbet mentioned in a letter to Alfred Bruyas dated December 1854 that he would like Bruyas to send him "that photograph of a nude woman about which I have spoken to you. She will be behind my chair in the middle of the painting... Send me as soon as possible the two 
profiles and the photograph of the nude woman." 52 The profiles that Courbet said he wanted sent to him were a side profile side of himself and another of Bruyas, which would be used in The Artist's Studio from 1854-1855 (fig. 4). This request to have the two profiles and the photograph of the nude sent at the same time, and the manner in which Courbet said he would he would place the nude female within the composition, matches the figures in The Artist's Studio. There is no clear indication that lists exactly what photograph Courbet mentioned, but Aaron Scharf argues that the source of the photograph was from Vallou de Villeneuve, a proposal that has been widely accepted by Courbet scholars. ${ }^{53}$ The photograph that has the most similarities was registered in 1853 , almost ten years prior to the painting being created (fig. 5). ${ }^{54}$

Other examples of figures within Courbet's paintings that have similarities to Vallou de Villeneuve's photographs appear in the 1853 painting The Bathers, (fig. 6) and the 1866 painting, Woman with a Parrot (fig. 7). ${ }^{55}$ The nude female figures in both paintings have poses that mirror those within photographs from Vallou de Villeneuve's series. Few differences exist between the pose of Vallou de Villeneuve's woman and Courbet's main figure in The Bathers (fig. 8). The white cloth wrapped around the buttocks of Vallou de Villeneuve's model, the slight lift of her left heel off of the ground, and her head turned and glancing to her right, are all echoed in Courbet's bather. The motion of the outstretched arm is similar, but the angle at which the arm is lifted differs, and the shortened fabric around the body is another of the most apparent modifications. Even the hairstyle of the female figure and the small detail that she is wearing earrings, the slight reflection of which can be noted in both, is paralleled.

\footnotetext{
${ }^{52}$ Courbet, Letters, 129.

${ }^{53}$ Griselda Pollock, Visual Politics of Psychoanalysis: Art in Post-Traumatic Cultures, (London: I.B. Tauris), 2013, 94.

${ }^{54}$ Pollock, Visual Politics, 94. To avoid being accused of photographing pornographic scenes or for illicit purposes, nude photographs were required to be registered as academies or artist's models. Courbet used photographs that were registered under this subject as well.

${ }^{55}$ For more comparisons, see Font-Réaulx, 342-373.
} 
Not all of Courbet's models can be identified, but he did have the tendency to reuse models throughout his career. The most recognizable is Joanna Hiffernan, who Courbet painted several times. ${ }^{56}$ The first portrait he did of her was Jo, La Belle Irlandaise, 1865-1866, completed during a stay in Trouville; he later made three variations of this painting (fig. 9). ${ }^{57}$ Jo was also the model for the blonde figure in The Sleepers, 1866, as she was traveling in Paris during the time of the painting's creation (fig. 10). ${ }^{58}$ A recent discovery has prompted speculation about what is proposed to be the second half of Courbet's Origin of the World, 1866, with a claim being made that a painting found of an upper half of a female figure was part of the original painting and was later cropped from the now final version. ${ }^{59}$ The discovery of this painting with a woman's face, which is argued to be Jo, suggests that she was the original sitter for the painting. ${ }^{60}$

Perhaps an amalgamation of Vallou de Villeneuve's model's pose with the likeness of the model Jo, Courbet's Woman with a Parrot, 1866 (fig. 7), merges the two physical similarities into one. A photograph from 1853 by Vallou de Villeneuve shows a reclining nude with her right arm stretched above her head, holding a long string necklace which falls behind her waist and away from the viewer (fig. 11). Courbet's figure in Woman with a Parrot has the signature red-hued wavy hair of Jo, but is posed in the same reclining position from Vallou de

\footnotetext{
56 Jo was also the model and mistress of James McNeil Whistler. It was suggested that the crumbling relationship between Courbet and Whistler, which ended in 1867, was due to possible intimacy between Courbet and Jo. Dorothy Kosinski, 'Gustave Courbet's 'The Sleepers.' The Lesbian Image in Nineteenth-Century French Art and Literature", Artibus et Historiae, vol. 9, no. 18 (1988): 197.

${ }^{57}$ Font-Réaulx, 332-333.

${ }^{58}$ Font-Réaulx, 362-363.

${ }^{59}$ Devorah Lauter, "Has the Head of the Origin of the World Been Found?" The Telegraph, February 10, 2013, accessed October 6, 2014, http://www.telegraph.co.uk/culture/art/9860793/Has-the-head-of-The-Origin-of-theWorld-been-found.html.

${ }^{60}$ No in-depth and conclusive research has been completed that would confirm nor deny this theory, but the painting's discovery in 2013 has led some to believe that this work is the upper half of The Origin of the World, but many reject the hypothesis that the two were originally one painting. Henry Samuel, "Amateur art buff finds $£ 35$ million head of Courbet masterpiece," The Telegraph, February 7, 2013, accessed February 8, 2013, http://www.telegraph.co.uk/news/worldnews/europe/france/9854914/Amateur-art-buff-finds-35-million-head-ofCourbet-masterpiece.html.
} 
Villeneuve's photograph. Both images depict fabric, draping behind the figures and also underneath the body. The time-frame of the painting's completion does fit within the period in which Jo was in Paris, and was also in the same year Jo posed for Courbet's The Sleepers. Many other Courbet paintings, both nudes and portraits, include the same female models. He appeared to be comfortable using the same model and sitter for his paintings, a tactic which made them recognizable to the viewer.

Courbet's first painted nude that was viewed at the time as scandalous was The Bathers (fig. 6), completed in 1853. At first glance, this painting is reminiscent of mythological scenes of nymphs and goddesses bathing in the open woods, such as ones depicted in Peter Paul Rubens'Venus and Adonis, c. 1630's (fig. 12). But Courbet's women were represented in a different manner from the Renaissance and Baroque masters before him and from his contemporaries, like Alexandre Cabanel. These dimpled and dirty bourgeois women were fleshy and voluptuous, differing from the plump yet idealized women that were often represented. The Bathers marked Courbet's first portrayal of a female form in such a conventional manner.

Courbet painted two women in a woodland setting, one stepping out from a wading pool and the other sitting on the forest floor. This representation initially conjures up images of Diana and her nymphs, or Venus at her bath - a goddess with her maidservants. The standing female figure, nude except for the crisp, white linen wrapped around the underside of her bottom and clasped in her left hand in front of her, is far from the idyllic women seen in the Salons and galleries, with her voluptuous figure curvy with dimpled skin. Edmond About, a critic of the work, described the figure:

She is not so much a woman as a column of flesh, a rough-hewn tree-trunk, a solid. The artist has handled the human figure like a still life... The most surprising thing about it is that this ponderous woman of bronze, articulated in 
layers like a rhinoceros, has faultlessly delicate knees, ankles, and all joints in general. ${ }^{61}$

While only the backside of this figure can be seen in the painting, the other female is seated to the right, facing the viewer with her head turned up towards the standing woman as if at this moment she is caught in mid-conversation. Her grimy clothes, unrolled stockings, dirty feet and head-covering suggest that she is not any sort of classicized figure, but rather a realistic version of a maid or servant, one a nineteenth-century viewer could easily identify and place. These women are unaware of any presence other than their own, and their candid nature expresses this sense of realism. This depiction was far from any classicized nude that had been displayed in the Salon during the late eighteenth and nineteenth-centuries. ${ }^{62}$

The decision to represent voluptuous, realistic women within a setting that was associated with images of Greco-Roman mythology exemplified Courbet's desire to merge aspects of the past, through illustrations that audiences were familiar with, and intersect those images with the present-day. While this particular painting may not have any specific politically charged agenda or an air of satire as some of his others, it demonstrates the artist's practice of linking recognizable depictions, in terms of mythological tones and locale, with contemporary themes. This painting also demonstrated the beginning of erotically charged paintings within Courbet's oeuvre.

The women Courbet depicted in The Bathers, while illustrated as nude, carry no connotations of sexuality or eroticism. His placement of the figures within the setting, along with the treatment of the bodies themselves, does not present a sensual tone to the viewer. The physical presentation of the women themselves was found more atrocious and disturbing than the

\footnotetext{
${ }^{61}$ Edmond About, Nos Artistes au Salon de 1857, (Paris: L. Hachette et Cie., 1858), 150-151.

${ }^{62}$ Paintings that displayed mythology, such as François Gérard's Cupid and Psyche, 1789, and Anne-Louis Girodet's Pygmalion and Galatea, 1819, were both exhibited in the Salons and depicted idealized women within romantic mythological settings.
} 
scene represented. This impression of sexual neutrality differs greatly from Courbet's 1857 painting, Demoiselles des bords de la Seine, or Young Ladies on the Banks of the Seine, which garnered much criticism for its overt sexuality, despite the figures being fully clothed.

Courbet's painting of two young women lounging on the banks of the Parisian river underneath a shady tree, a boat floating just past them on the shore, was met with strongly negative reactions. Champfleury had said of the painting, "As to the Young Women, horrible! Horrible! Certainly Courbet knows nothing about women. You'll think me embittered. I've always told you that since Burial our friend has gone astray. He has kept his finger too much on the pulse of public opinion...."63 The present day viewer may see nothing immoral within this painting, but Courbet has displayed these two young women in a manner in which they appear to be prostitutes. The choice of the artist to use demoiselles in the title of the painting even enraged some; Maxine du Camp insisted that these women were "lorettes," another name for a prostitute, which is a reference to the area in Paris which one would find a woman in such a profession. ${ }^{64}$ These young women have displayed themselves in a provocative manner, being shown in essentially their undergarments, especially the brunette figure in the foreground. This exposure of lingerie would have been immediately noticeable to any nineteenth-century viewer and the connotation of the women as having "loose morals" would have been instantly perceived. ${ }^{65}$ If it is the case that these two female figures are prostitutes, then where would their male suitors be? The illustrated absence of a male in this sexually charged painting could also suggest that perhaps we are viewing a homosexual encounter between these two women, a theme that would

\footnotetext{
${ }^{63}$ Jack Lindsay, Gustave Courbet: His Life and Art, (London: Harper and Row, 1973), 151.

${ }^{64}$ Reilly, 129.

${ }^{65}$ Reilly, 128.
} 
present itself in other Courbet paintings in which only two female figures are depicted. ${ }^{66}$ The provocative nature in which Courbet presents these clothed women, with veiled eroticism despite being fully clothed, further marks the increase of the sexuality within his paintings.

The term "lesbian" and how it is used in the twenty-first century differs greatly from previous definitions. Today, the term refers to a woman whose sexual proclivities are aimed towards the female gender; someone in the nineteenth-century would have a much broader meaning. Some of these women may have been involved in sexual relations with other females, but many who were not sexually involved with women were labeled as lesbians because of their rejection of traditional and socially acceptable roles - those known as Amazons, androgynous, bluestockings, whores and witches fell into this characterization. ${ }^{67}$ In nineteenth-century France, many words were used interchangeably that denoted woman who preferred the same sex: tribade, gougnotte, lorette, sapphienne, petites soeurs, les deux amies, la fleur du mal. ${ }^{68}$

Regardless of their sexual orientation, women who chose intellectual pursuits, political positions, and social revolutionaries who appeared to shirk their domestic duties were not accepted into society during this time and were often typecast as lesbians. ${ }^{69}$ Pierre-Joseph Proudhon, a well-known philosopher and friend of Courbet's, argued that a woman's responsibility was in the home, to care for her children and husband. ${ }^{70}$ Any deviance from this role was seen as insubordinate and revolutionary. In this strict, two-gender society, the rejection of one role was the tacit acceptance of another, leading women who chose to pursue any function that was outside of the domestic to be characterized as a lesbian.

\footnotetext{
${ }^{66}$ Font-Réaulx, 318-319. In the background of the painting, a hat can be seen in the boat, which is thought by some to be that an indication of a male companion.

${ }^{67}$ Reilly, 20-21.

${ }^{68}$ Reilly, 18-19.

${ }^{69}$ Reilly, 16-31.

${ }^{70}$ Chu, "Uneasy Nudity," 41.
} 
The inclusion of women in any political role was rare during this time in France, and usually met with resistance. Feminist Jeanne Deroin was the first woman to apply for office in the French government in April 1849 and she was met with much opposition. Proudhon commented on her candidacy, responding, "We no better understand a woman legislator than we do a male wet-nurse."71 The reaction this caused, as exemplified by Proudhon's response, reinforced the public notion that women were not meant for positions outside of the home. ${ }^{72}$ Her rejection of the traditional role in exchange for a more liberated and outspoken position challenged the conventions of the French and in turn, became the equivalent of lesbianism. ${ }^{73}$

Rebellious female figures, such as Deroin, and even the nineteenth-century portrayal of the Medieval figure Joan of Arc, were not the only individuals to be branded with the label of lesbian. Marie Antoinette, the French queen who lived almost a century before Courbet, was accused of lesbianism shortly before the start of the French Revolution. ${ }^{74}$ For supporters of the French upheaval, the negative imagery that portrayed royal figures in obscene actions only stimulated and encouraged a rebellion against the extravagant regime. The defamation of political or revolutionary individuals, along with the increase of homosexuality in nineteenthcentury literature, intensified the public interest in women having sexual relations with other women. ${ }^{75}$

Literary representations of homosexuality between women were prevalent during the decades prior to the creation of Courbet's Venus and Psyche. The 1820's and 1830's saw an

\footnotetext{
${ }^{71}$ Reilly, 29 quoted from Daumier.

72 Reilly, 28-29.

${ }^{73}$ Reilly, 28-29. Reilly states that women, such as Deroin, were perceived as a "menace to society and the nation, threatening the established order that they were meant to uphold."

${ }^{74}$ Martha Vicinus, "“"The Wonder to Which Sex I Belong”: The Historical Roots of the Modern Lesbian Identity," Feminist Studies, vol. 18, no. 3 (Autumn 1992): 476.

75 Reilly, 11.
} 
upsurge of writings that were centered around or included lesbianism. ${ }^{76}$ Writers like Honoré de Balzac, Charles Baudelaire and Théophile Gautier composed literature that incorporated a lesbian figure, but the first presentation of a lesbian in French literature was Henri de Latouche's Fragoletta: Naples et Paris 1799, which was published in $1829 .{ }^{77}$ This text was most likely the influence for much of the literature of the 1830's and 1840's, including that of Georges Sand, who was known for not only her literary compositions but perhaps more so for her genderbending persona. ${ }^{78}$

In Sand's 1833 novel Lélia, her first novel that incorporates the theme of lesbianism, she includes a scene where the two main characters, sisters Pulchérie, a courtesan, and Lélia, recall a moment from their childhood. ${ }^{79}$ This memory consists of the two sisters napping along the banks of a stream, when Pulchérie has a dream of a dark haired man, but awoke to find Lélia attractive in a manner that she had not previously known. This erotic encounter experienced between the two sisters, as well as the description of the individuals, has similarities to Courbet's Young Ladies on the Banks of the Seine, 1857 (fig. 13). ${ }^{80}$ The resemblances between the two figures are striking and the identification of the "ladies" as working women would coincide with

\footnotetext{
${ }^{76}$ Reilly, 21.

${ }^{77}$ Reilly, 42-44.

${ }^{78}$ Reilly, 32-36, 51. Perhaps better known for her personal life than her career, Reilly notes that Alexandre Dumas called her a "female Don Juan".

${ }^{79}$ Georges Sand, Lélia, (Paris: Michel Lévy Fréres, Libraries Éditeurs, 1867), accessed January 26, 2014, http://www.gutenberg.org/files/39738/39738-h/39738-h.htm. The original publication of this novel was in 1833, however, due to its scandalous subject matter, it was reprinted in 1839 and some of the stronger lesbian scenes were deleted from the 1839 version and versions printed later.

${ }^{80}$ Sand writes, "Your thick black hair stuck to your forehead, and tight curls rolled on themselves as if a sense of the life he had clenched at your neck velvety shade and sweat... Your fine white shirt, tight to your breast, did your skin look tanned by the sun..." The ladies featured in Courbet's Demoiselles painting were not viewed by Salon patrons as young girls, but rather as cocettes, or fashionable prostitutes, perhaps relaxing on the banks of the river waiting for their next client. Could the figure in the background of Courbet's painting be his interpretation of Pulchérie, who has just woken from her nap, still hazy from dreams of the dark haired man? That would make the foreground figure, who appears to be sleeping but her eyes are slightly parted, Lélia? She does match the description provided in Sand's novel: dark hair curled up along her neck, a white shirt and dress clinging to her body, her eyelids a darker shade than her cheeks. This is an interesting likeness to note and it would be worthwhile to further explore this topic at a later date.
} 
Sand's Pulcherie character. ${ }^{81}$ Regardless, Georges Sand had a role in introducing lesbianism in public literature, and perhaps influencing art, by challenging the male role. This popularizing and assimilation of the homosexual character into contemporary arts was received with much negativity, both from the public and also from Sand's fellow authors, garnering interest for her literature for its scandalous matter, much like Courbet, instead of the excellence of material. ${ }^{82}$

${ }^{81}$ It is an interesting concept to think that Courbet read Sand's novels and used the writings as a muse for his characters attributes and that these details are not purely coincidence.

${ }^{82}$ Reilly, 46. 


\section{III: Philosophical Influence}

The philosophies of Pierre-Joseph Proudhon, 1809-1865, ranged over a wide variety of topics, from economics and politics to feminism and art. ${ }^{83}$ Proudhon's life had some striking similarities to Courbet's; both were native to the Besançon area, struggled with the regime of Napoleon III, and at some point in their life had imposed self-exile upon themselves. The political beliefs of Proudhon were not shared by those of the reigning administration and Napoleon III had the philosopher imprisoned from 1849-1852 for negative comments he made. Proudhon was exiled to Belgium from 1858 until he was freed in 1862, and returned to France in 1863 after its liberation, where he remained until his death in 1865 . Courbet's interactions with the government were not as undesirable as Proudhon's; however, the two shared a bond of republicanism and a desire for political revolution in order to strengthen France.

Courbet's admiration of the philosopher is visible in his letters to both Proudhon and also to others where he is mentioned, but some authors have speculated that this appreciation was one-sided, with Courbet being fonder of Proudhon and his theories than the philosopher was of the artist. ${ }^{84}$ Regardless of the nature of the relationship between Courbet and Proudhon, the influence between the philosopher's theories and their impact on the artist's paintings is important to recognize. In the months before Proudhon's death and the completion of Venus and Psyche for the 1864 Salon, a collaboration between the artist and the philosopher had already begun. This was initiated in 1863 when Courbet asked Proudhon to write a short commentary

\footnotetext{
${ }^{83}$ A socialist, economist, and self-declared anarchist, some of Proudhon's writings include, The System of Economic Traditions, 1846, General Idea of the Revolution in the Nineteenth Century, 1851, Of the Political Capacity of the Working Class, 1865, and Theory of Property, 1866.

${ }^{84}$ See Alan Bowness, “Courbet’s Proudhon”, The Burlington Magazine, vol. 120, no. 900, (March, 1978), 123-130, and also O'Connell, "Art at the Barricade," 2011.
} 
that would accompany The Return from the Conference (fig. 14) for an exhibition in London. ${ }^{85}$

This commentary, which originally was a mere four pages, developed into a full-length book, $D u$ principe de l'art et de destination sociale, in which Proudhon discussed art and society from not just the nineteenth century, but from the Egyptians forward. Courbet and his paintings were mentioned in this text, which provides the reader with an insight into what could have prompted

Courbet's Venus and Psyche and provide insight into the context in which this painting was produced, which may compliment Proudhon's theories. Proudhon wrote:

One day in his painting of Venus and Psyche, refused in 1864, Courbet tried to make in painting what such moralists as Ezekiel and Juvenal have done in poetry: a satire on the abominations of his time. But the means of the painter are not those of the writer. He would not dare to paint the phalluses of the Assyrians and the Egyptians; he would not dare to show Ooliba in the posture described by the prophet...; he could not show us Messaline after her twenty-fifth copulation; nor that other woman bellowing like a rutting deer at the sign of an artist; nor the woman who pissed in the moonlight against the statue of Modesty; not the one of whom it was said: Ipsa medullinae frictum crissantis adorat.

Those things are impossible in painting. The painter has therefore been forced to use a disguise [He has used] no gesture that shows even the slightest indecency; no pose that suggests the slightest lewdness; not even complete nudity. [Instead, he shows us] a sleeping blonde, who a young girl would naturally take for a Psyche waiting for Amor; a brunette comes tiptoeing through the dark and looks at her with a glance that can express jealousy, as well as other things....

One must be informed to understand the artist. One must have read George Sand (Lélia), Theophile Gautier (Mademoiselle de Maupin); one must know the hypocrisy of the sense of propriety of our time. One must remember that Courbet has been blamed for not being able to paint the nude, and that he blames his critics for not appreciating in the nude anything but desire [volupté]... One must have seen the exhibitions of the last few years; one must know that $\mathrm{M}$. de Nieuwerkerke has made the emperor buy a Leda with a swan between her legs...

It is to that entire world that Courbet says through his painting: "You are a bunch of lechers and hypocrites; I know you; I know what you want and what your pimps are asking for you. You are not interested in the art of painting the nude; you are not hungry for natural beauty, but for dirt. Here, this is how one paints the

\footnotetext{
${ }^{85}$ Joshua C. Taylor, ed., Nineteenth-Century Theories of Art (Berkeley, CA: University of California Press, 1987),
} 384. 
nude, and I defy you to do the same. And that is what you are all looking for, you race of pederasts and lesbians. ${ }^{86}$

Proudhon's statement, particularly the last paragraph, supports the theory that these paintings were not merely works representing mythological subjects, but rather their intention and aim was to criticize and condemn the government. Chu notes that it would seem unusual for Proudhon to have suggested the subject matter to Courbet; however, it would not be uncommon for the artist to depict something that would support a theory of one of his advocates. ${ }^{87}$ The belief that the concept of the Venus and Psyche painting came solely from Proudhon would appear to be questionable in that it would not be typical of Courbet to present something that the artist himself had no connection to or beliefs that he shared. The artist's desire to be associated with Proudhon could have prompted the painting, in order to tie the philosopher's theories about women and the government to Courbet, an association that would certainly boost Courbet's political role and garner interest for his artwork. Courbet had expressed his opinions through his art, but was not the mouthpiece of another individual, suggesting that while Proudhon's theories may be the foundation for these paintings, they were not the sole concept portrayed.

Proudhon's theories on women and their role within the family were fully expressed in his La Pornocratie ou les femmes dans les temps moderns, published after his death in 1865, but written in the years before that. In it, Proudhon states that the family is the "nucleus" of the republican state; disturbing this balance through any actions, such as prostitution, pornography or

\footnotetext{
${ }^{86}$ Pierre-Joseph Proudhon, Du principe de l'art et de sa destination sociale, (Paris: Garnier, 1865), 261. The translation of this text was completed and included in Chu, "Uneasy Nudity," 41.

${ }^{87}$ Chu, "Uneasy Nudity," 42.
} 
women's liberation, would destroy any stability. ${ }^{88}$ As Chu points out, the selection of the title of the work represented Proudhon's disgust towards the Second Empire; a governing body that he felt embodied despotism, corruption and debauchery. ${ }^{89}$ When considering the nineteenth-century viewer that would have observed Courbet's Venus and Psyche, the negative governmental concepts of Proudhonian theories began to emerge from the painting.

${ }^{88}$ Chu, "Uneasy Nudity," 41-44. When Proudhon uses the term 'prostitute', one must keep in mind that in Proudhon's theories, anyone that shunned any domestic duties were then seen as prostitute, regardless of if they actually sold sexual favors in return for monetary compensation.

${ }^{89}$ Chu, "Uneasy Nudity," 41-44. 


\section{IV: The Second Empire and Courbet}

December 1851 marked a monumental time for the country of France; Louis-Napoleon staged his coup d'état, dissolved the Assembly, and announced a new constitution. After he crowned himself Emperor of France, and changed his name to Napoleon III, he ended the Second Republic and the Second Empire of France began. Within this administration Courbet had many admirers, such as the Comte de Morny, but he also had several detractors. ${ }^{90}$ In a letter from June 1852 to his family, Courbet stated that Morny said he would speak to the government about having more works commissioned from him. In the same letter, Courbet also reveals a conversation that he had with the Director of the Fine Arts Administration, Auguste Romieu. "On the other hand, M. Romieu, who is the director of the Fine Arts Administration, has declared that he would give me none at all; that the government could not support a man like me; that, were I to do other kinds of paintings, he would see what he could do; that, moreover, I was perceived as a political force and that they were not afraid of me." ${ }^{91}$ This admission from Romieu, an acknowledgement from the administration that Courbet's paintings were problematic and that he was a "political force" even before he began painting works critical of politics and religion, suggests an early tension between the government and the artist.

It appears that this conversation did not discourage the artist enough for him to change his style of painting and perhaps it even became the catalyst for his controversial works and a source for his negative viewpoint against the government. Courbet wrote, "It is impossible to tell you all the insults my painting of this year has won me, but I don't care, for when I am no

\footnotetext{
${ }^{90}$ The Comte de Morny, later Duc, the illegitimate half-brother of Napoleon III, frequently purchased Courbet's works and was perhaps his largest supporter within the Second Empire regime. Among the works that he purchased from the artist is Young Ladies of the Village, 1851, shown in the 1852 Salon.

${ }^{91}$ Courbet, Letters, 107.
} 
longer controversial I will no longer be important."92 This attitude was one that Courbet carried throughout the rest of his career, as he realized that once he no longer created contentious art, he would no longer be relevant to the public.

Courbet's 1853 painting, The Bathers (fig. 6), provocative in its representation of women, prompted attention not only from the public and critics, but also the Emperor himself. Upon seeing the work, it is reported that Napoleon III slapped the behind of the standing figure with his riding crop, a gesture that indicated his distaste for the work and disgust. ${ }^{93}$ Princess Eugénie, his wife, reacted in a slightly differently manner; after viewing Rosa Bonheur's The Horse Fair, 1853-1855, which was also exhibited at the Salon and seen earlier by the royals, asked if the nude figure in Courbet's was a Percheron as well, referring to the massive horses seen in the equine painting. ${ }^{94}$ Once Courbet was made aware of the reactions by the emperor and his wife after viewing his work, the artist stated that, "If I had only foreseen this spanking I should have used a thin canvas; he would have torn a hole in it, and we should have had a splendid political lawsuit...."95 For a response such as this to be aimed towards the leader of the country, and a potential buyer and patron of his artworks, shows the callous and disinterested sentiments that the artist had towards the government. Should Courbet have made that comment to a critic, it might not have hindered his career much in terms of commissions and purchases of his art, but to criticize the ruling party and to threaten a lawsuit could have resulted in many repercussions towards him, both professionally and personally.

Later in the year, the Comte de Nieuwerkerke, who at the time was the head of the Salon jury, met with Courbet to discuss potential commissions for the government. In a letter dated

\footnotetext{
${ }^{92}$ Mack, 106.

${ }^{93}$ Mack, 106.

${ }^{94}$ Mack, 106.

${ }^{95}$ Mack, 106.
} 
October 1853 to Alfred Bruyas, Courbet discussed the meeting with Nieuwerkerke, which would be the first of many interactions between the two. The motive for the meeting was that Nieuwerkerke, and the government, wanted Courbet to create a work for the upcoming Exposition Universelle of 1855, an international exhibition in Paris. ${ }^{96}$ The main caveat to the government's proposal was that Courbet would have to present a sketch of the painting before beginning work on it and that after the final painting was finished, it would be submitted to a committee of artists for approval. In addition to this, Nieuwerkerke asked that the artist "change his ideas, water my wine; that everyone was entirely on my side; that I mustn't be contrary, etc." 97 This commission was to be supplemented with a lump sum of money, essentially proposing that the government would buy Courbet's silence and obedience. After the artist flatly refused, Nieuwerkerke requested that Courbet send nothing to the exhibition, insulting and angering him even further. ${ }^{98}$ Perhaps the most intriguing part of the conversation recalled by Courbet is the statement:

He went on to tell me that he was quite unhappy that 'there are people like you in the world'; that they were born to destroy the finest organizations; and that I would be a striking example of that. I started to laugh till the tears came to my eyes and assured him that only he and the academies would be the victims of that. ${ }^{99}$

This conversation brings to light the knowledge that the government was aware of the damage and danger that Courbet was to the regime, reinforcing the cautions that Romieu had spoken of earlier in the year. The offer to buy off an artist, and a vocally opinionated one at that, and then to withdraw the offer and instead request he submit nothing to an international

\footnotetext{
${ }^{96}$ Mack, 112.

${ }^{97}$ Courbet, Letters, 115.

98 Courbet, Letters, 116.

${ }^{99}$ Courbet, Letters, 116.
} 
exhibition appears to be tacit agreement that Courbet posed a problem to the positive representation of the government.

This meeting between Courbet and Nieuwerkerke is significant to note because of the proposal that the Superintendent suggested to the artist. Throughout the Second Empire, Napoleon III made attempts to gain the allegiance of artists, especially from prominent artists of the time, in order to have them collaborate and create works for him. ${ }^{100}$ These alliances and the artworks created because of them would have curbed the negative press reported about the ruler and his regime, acting, perhaps, as an informal method of censorship. This went against the standards that Courbet had emphasized of Realist artists; he believed that an artist's obligation was to take an active role in shaping the world through their work, not to create falsely positive images of the government. ${ }^{101}$ Any artist taking on propagandistic actions for the government would be rejecting the ideals of Realism, and in reaction to this proposition Courbet began creating propagandistic paintings that displayed the negative aspect of the administration, quite the opposite of the portrayals that Napoleon III encouraged. The altercation between the Nieuwerkerke and Courbet became the starting point for the artist's artistic attacks against the government, one of the earliest and most apparent being the separation between "good" and “evil” in Courbet's The Artist's Studio.

In Courbet's large-scale painting, The Artist's Studio, he became more willing to express that his works contained several layers of meaning, although these may have been unidentified at the time it was created. ${ }^{102}$ Created between 1854-1855, the full title of the work was The Artist's Studio: A Real Allegory Summarizing A Period of Seven Years of My Life as an Artist, (fig. 15)

\footnotetext{
${ }^{100}$ Paul B. Crapo, “The Problematics of Artistic Patronage under the Second Empire: Gustave Courbet's Involved Relations with the Regime of Napoleon III," Zietschrift für Kunstgeschichte, 58. Bd., H 2 (1995), 241.

101 Crapo, 241.

102 It was not until later that the multiple layers of interpretation of the painting were discerned. The aforementioned 1977 exhibition catalogue by Hélène Toussaint explains these theories. Toussaint, 134.
} 
and within this larger than life-size painting, Courbet reverted back to the figure-filled representation that he had earlier depicted in Burial at Ornans. As suggested earlier, and also indicated by the artist in the name of this painting, this exhibited an allegory of part of Courbet's early artistic life. With his detractors on his left and his supporters on the right, identification of the individuals within the painting is crucial in order to hypothesize Courbet's negative attitude at that moment not only towards the people in his life, but the actions surrounding him and the perception of the state of his country. ${ }^{103}$ The identification of the figures as split between advocates on the right and disparagers on the left, and the inclusion of several government figures within the group of disparagers on the left, suggests the animosity between Courbet and the administration of Napoleon III. ${ }^{104}$ If not at odds during the creation and completion of this painting, what other reason would Courbet have to purposefully represent government officials as his acknowledged critics? To specifically paint a disguised Emperor amongst a beggar, a priest, and others, symbolized Courbet's disdain and disrespect. The artist's decision to isolate and classify groups of individuals demonstrated the deep consideration that went into this paintings' construction, and the segregation of persons exemplifies the hostility present between the artist and the government during the time of its creation.

In the year prior to the creation of the original Venus and Psyche, Courbet submitted Return from the Conference to the Salon of 1863 (fig. 14). The scene depicts one inebriated man falling off the back of a donkey with several drunken priests stumbling alongside him down a country road while onlookers stand to watch their march. The painting's obvious anti-clerical sentiments were considered to be immoral and the painting was flatly refused from the Salon.

\footnotetext{
103 Toussaint, 134.

104 Toussaint, 134.
} 
According to his letters, Courbet was aware when he submitted the work that the piece would be seen as provocative and would cause some media scandal, which was his intention. ${ }^{105}$

During 1863 not only was a Salon being held, but due to an unprecedented number of refusals from the jury, and the subsequent disapproval from artists, Napoleon III ordered that an exhibit titled the Salon des Refusés open, which would showcase the enormous number of rejected artworks, some of those which were deemed unworthy or immoral for the formal Salon exhibit. ${ }^{106}$ When Courbet had been made aware that his painting had been rejected from the Salon, but that there would be an exhibit featuring all refused works, he seemed content that Return from the Conference could be shown in this additional show. In a letter dated April 23, 1863 to Albert de la Fizelière, Courbet wrote,

I had submitted a painting of priests, very true to life, the Return from a Conference. It corresponded rather well to the emperor's insult of last year, and also to what is happening with the clergy. The painting hit home, it went straight to its author. It has been taken down and rehung three or four times. If one were to talk to Walewski, it could perhaps be hung a fifth time. I painted the picture so it would be refused. I have succeeded. That way it would bring me some money... ${ }^{107}$

If Courbet was aiming for refusal, he succeeded; the painting was rejected not only from the Salon, but also the Salon des Refusés.

This "insult" that Courbet referenced is the rumor that the emperor had personally removed Courbet's name from the list of artists that were to be awarded medals at the 1861 Salon. ${ }^{108}$ With the painting's refusal from both exhibitions, Courbet began exhibiting the work

\footnotetext{
105 Courbet, Letters, 220.

106 Albert Boime, "Edouard Manet: Man About Town," Art in an Age of Civil Struggle, 1848-1871, (Chicago: University of Chicago Press, 2007), 685.

107 Alexandre Walewski, 1810-1868, was the minister of state since 1860 and the illegitimate son of Napoleon III and his mistress Countess Marie Walewski.

107 Courbet, Letters, 220.

${ }^{108}$ Courbet, Letters, 220.
} 
in other venues across Europe, and in his own studio where he charged admission. ${ }^{109}$ Eventually, it was purchased by a religious extremist, was cut up and destroyed. Even photographs of the painting are hard to come by, as the police, according to an April 1867 letter from Courbet to Castagnary, destroyed the negatives. ${ }^{110}$ This incident surrounding the painting outlines the tension between the emperor and the artist, indicating the adversarial relationship between the two.

Though he studied works of the great masters, which included mythological paintings, Courbet was not interested in creating the same style and genres of works that his predecessors had. In the 1852 catalogue for his Realism exhibit, Courbet wrote, "I have studied, outside of any systems and without prejudice, the art of the old masters and the art of the moderns. I have no more wished to copy the one than to imitate the other; nor has my idea been to achieve the vain ends of art for art's sake." 111 That being said, it would seem to make sense that the artist who is known for intentionally creating discord with his works would again attempt to do so with other paintings, just perhaps in a different genre and style, specifically mythological paintings with nude themes. But the question is who, or what, Courbet might be referencing in Venus and Psyche. Taking into account the previous year's issues with the Salon that Courbet had encountered, and the social and artistic philosophies of Proudhon, perhaps his target was the government. Courbet was very open about his dislike for the Superintendent, and judging by his negative comments about Realism, Nieuwerkerke was not fond of the artist or the artistic style. Knowing that there was a strong sense of animosity between the two figures, and Courbet's history of creating satirical and critical works, could Courbet have narrowed his critical viewpoint down to one subject for a particular painting - Nieuwerkerke?

\footnotetext{
${ }^{109}$ Lindsay, 182.

${ }^{110}$ Lindsay, 182.

${ }^{111}$ Gustave Courbet, Realism (from the preface to the 1855 catalogue), from Taylor, 347.
} 
The altercation between Nieuwerkerke and Courbet in 1852 was the first of many conversations between the two in which they clashed. Nieuwerkerke's wish for Courbet to "weaken" his art that spoke against society and the government was not well received by the artist and this 1852 meeting appears to have set the tone for the relationship between the two. Perhaps it was Nieuwerkerke's powerful position as Superintendent of the Arts, or his poor rapport with Courbet, but whatever the reason, the artist may have been taking aim at the French administration, and perhaps even Nieuwerkerke, within his Venus and Psyche paintings while referencing Proudhon's theories.

Émilien de Nieuwerkerke, later comte, was the successor of Frèdèric Bourgeois de Mercey, 1803-1860, who was the Superintendent and head of the Fine Arts Administration, and also a friend to many artists including Courbet. Eugene Delacroix wrote about Mercey’s admiration for Courbet during his remarks regarding Courbet's solo exhibition, which was opposite the Universal Exposition of $1855 .{ }^{112}$ In this article, Delacroix mentions that Mercey had high esteem for the artist, quite the opposite of his replacement. ${ }^{113}$ After Mercey's death in 1860, Princess Mathilde Bonaparte was quick to have Nieuwerkerke named as Superintendent, taking over the position of his rival, he claimed the coveted governmental position that he had longed to obtain. ${ }^{114}$ Assistance from the Princess in the naming of Nieuwerkerke was not prompted solely by her concern in the arts; she also had a personal interest in the appointment. Mathilde Bonaparte, 1820-1904, was the cousin of Napoleon III and was originally set to marry the future emperor, but this engagement was broken due to his imprisonment in 1841 . Later that year, she married Anatole Demidoff, a Russian prince whose family was well known

\footnotetext{
112 Courbet's rival exhibition came about after the 1852 meeting with Nieuwerkerke.

113 As noted in Patricia Mainardi, Art and Politics of the Second Empire: The Universal Expositions of 1855 and 1867, (New Haven: Yale University Press, 1987), 96, from Eugène Delacroix, Journal, 1822-1863, ed. André Joubin (Paris, 1870), 3 August 1855.

${ }^{114}$ Mainardi, 36.
} 
for their extensive collection of jewels. No less than two years into their marriage, both took up lovers, with the Princess's being Nieuwerkerke; their affair was not secret to many. ${ }^{115}$ Demidoff and Mathilde were separated in 1845 and the princess kept her well-known collection of jewelry and diamonds from the marriage. Mathilde and Nieuwerkerke carried on with this relationship for many years, parting ways from each other in late $1869 .{ }^{116}$

The Salon of 1863 is arguably the most well-known French art Salon to date. While previous Salon juries were tasked with selecting a set number of paintings to be shown, this Salon had more restrictions than others, specifically in the number and quality of works that were accepted to be exhibited. ${ }^{117}$ Nieuwerkerke had recently enacted a new regulation that would restrict artists to submitting only three works to the Salon jury, severely limiting the chances that artists would have of being selected. In previous years, the number of submissions from an artist was unlimited. Nieuwerkerke's goal with this new rule was to force artists to submit more masterfully created pieces, instead of sending in every sketch or drawing they had completed, and thereby raising the caliber of art presented at the Salon. ${ }^{118}$ This ruling was strongly opposed by many artists. A petition with over hundred and eighty signatures, unifying both conservative and independent artists with their dislike for this parameter, was created and submitted to the

\footnotetext{
115 Mainardi, 35.

116 Mainardi, 126.

117 The French Salons played an integral and momentous role in the growth and success of any artist in the eighteenth and nineteenth centuries. Crucial not only to the development and accomplishment of artists, it provided society with the opportunity to view masterful works of art, a chance for young artists to blossom, and supported the advancement of culture in France. No longer were works of art confined to the private residences of royalty and the wealthy; they were displayed in community venues where the skills and techniques of fine artists could be appreciated and admired over by all, and provided artists the chance to become well-known in society, boosting their business and status. In the twenty-first century, the allure of observing paintings and sculptures is often forgotten, with the opportunities to see artwork and visiting museums no longer interest to many, perhaps due to its accessibility, however this was not the case during the past and the French Salons exhibit this significance and importance. Originated by the artistic academies specifically the French Royal Academy, these exhibitions allowed the artist, the patron and the public to collectively view art and praise or criticize the creations they saw. These showcases were successful and continued throughout France and spread through Europe, with other countries choosing to present their art in a similar fashion.

118 Albert Boime, "An Unpublished Petition Exemplifying the Oneness of the Community of Nineteenth-Century French Artists," Journal of the Warburg and Courtauld Institutes 33 (1970), 346.
} 
government. ${ }^{119}$ Jury members were also instructed to become stricter with the works they accepted, which limited the number of artworks to be shown. ${ }^{120}$ The individuals that made up the 1863 Salon jury were persons who shared many views with Nieuwerkerke, and possibly took into account his distaste for the Realist movement when considering submissions. The eightman jury was comprised of Jean Alaux, Jacques-Raymond Brascassat, Auguste Couder, François Heim, Joseph Robert-Fleury, Ernest Meissonier, François Picot, and Émile Signol. ${ }^{121}$ Meissonier was in the minority amongst the jurors in his acceptance of contemporary art, including Realism, and was against the stricter guidelines. He had even signed even the petition submitted with the artists against the new regulations. In a letter from artist Eugène Delacroix, Meissonier was quoted as saying, "I flatter myself that I can be of use there, because I shall be nearly alone in my opinion." ${ }^{\prime 22}$ Unfortunately being the only advocate for Realist art in the Salon jury would have meant that no matter his opinion on the submitted works, the older jurors would have ignored his views.

While many of these jury members were artists, their relationship with Nieuwerkerke and distaste for the contemporary style could have been the motivation for their rejection of art. Meissonier was forty-eight at the time of the Salon of 1863, and there was an eleven-year age gap between him and the second youngest member of the jury, Émile Signol. Of the eight jurors, half were over the age of seventy, many of whom had earned their honors during the July Monarchy and were followers of the Neoclassical style. ${ }^{123}$ Their allegiance to both the Academy

\footnotetext{
${ }^{119}$ Boime, "Unpublished Petition," 348-353. This petition was signed by over 100 artists including Jean-AugusteDominique Ingres, Edouard Manet, William-Adolphe Bouguereau.

${ }^{120}$ Boime, "Unpublished Petition," 346. Over 5000 pieces were submitted to be examined by the eight jurors over a three day period, meaning that the jury had to judge over 1650 artworks per day.

${ }^{121}$ Ross King, The Judgment of Paris, (New York: Walker and Company), 2006, 58.

${ }^{122}$ Eugène Delacroix, Correspondance générale de Eugène Delacroix, 5 vol., ed. André Joubin (Paris: Plon, 1937), vol. 3, 369. Delacroix served on the 1857 jury.

${ }^{123}$ King, 58.
} 
and also previous art movements that were out-of-date and dissimilar to Realism certainly affected their role as jury members, making them more inclined to accept paintings in accordance to their own artistic style and taste. With the current regime, and especially Nieuwerkerke, disapproving of the newer styles that artists were incorporating into their pieces, the emphasis on supporting and favoring art that was reminiscent of the older jurors' style was apparent.

Jury member François Picot, 1786-1868, strongly disliked Courbet and the Realist movement, as Courbet mentioned in a letter he wrote to Jules Castagnary in October 1868, just after Picot had died. "It is I who ought to replace M. Picot! M. Picot, who for seven years -either on his own or by means of his influence - caused me to be refused at the Exhibitions from 18401848, and for the best things I ever did in my life!"124 It was during the Salon of 1849, the first he sent any paintings to, that Courbet had submitted seven pictures, one of which was his notorious large-scale painting After Dinner at Ornans, 1849. This remarkable genre painting was responsible for Courbet receiving a second gold medal at the 1849 Salon, resulting in his obtaining hors concours, which guaranteed acceptance of all his submissions to future Salons. ${ }^{125}$ The single caveat with this award, which was later enforced, was that while it may have allowed Courbet to bypass any jury submission, any paintings that were deemed lewd or offensive were not exhibited, as was the case during the Salon of 1863.

This narrow-mindedness and old-fashioned taste of the Salon panel resulted in strong criticism and outcry from the public and artists, it was so great that their disapproval reached Napoleon III. He acknowledged the objection by creating the Salon des Refusés; an exhibition,

\footnotetext{
${ }^{124}$ Courbet, 345. Shortly after Picot had died, rumors began swirling that Courbet had put forth his name as a candidate for the position that Picot held at the Academy. However, Courbet stressed in his letter his aversion for the French Academy and established institutions.

125 Mack, 67.
} 
which would display the majority of the rejected art from the official Salon. Of the refused paintings, some works in particular stirred up controversy, such as Edouard Manet's Le Déjéuner sur l'Herbe, 1862-1863, and James McNeill Whistler's Symphony in White, No. 1: The White Girl, 1861-1862, which featured the previously mentioned popular model and Whistler's mistress, Joanna. Allowing the exhibition of these provocative paintings, as well as the work of many Realist painters, provided the public with the chance to view the pieces that went against the taste of jury members and was deemed unworthy. While Courbet was included in the lot of painters who were refused from the French Salon, it did not guarantee him admittance to the Salon des Refusés, and his Return from the Conference was also denied entrance into the additional Salon, shutting the doors on any opportunity Courbet would have to be viewed in a national Salon venue in 1863 . The blatantly anti-clerical painting of drunken priests riding donkeys was viewed with extreme disfavor and condemned by both the jury and art critics. 


\section{Venus and Psyche}

In late 1863 and early 1864, Courbet began two paintings, which were to be submitted, and hopefully exhibited, in the 1864 Paris Salon. The first, title unknown, depicted an assemblage of poets surrounding the Hippocrene Fountain; the second painting's title is also unknown, but it is thought that it was named Conscript's Departure. ${ }^{126}$ Unfortunately, both were destroyed during the final stages of completion and Courbet reluctantly painted a third work for the Salon, as he stated in a letter to Jules Luquet in February-March 1864. ${ }^{127}$ "I had the courage to undertake a third one. It is of two nude women, life size and painted in a manner that you have never seen me do." 128 In a letter dated March 3, 1864, Courbet described more about the painting to Etienne-François Haro.

The painting represents two life-size nude women. The subject is unimportant, if one wanted to give the painting a high-flown title one could call it Venus in Jealous Pursuit of Psyche. What I am telling you here is only to give you an idea of the composition of the painting for, until now, I had resolved to call it Study of Women in the catalog of the Exhibition. ${ }^{129}$

It is interesting to note that Courbet states that the subject of the work is unimportant and that the title of the piece is not something of significance to him. If the subject was not the main point of the work, then what reason would Courbet have to paint the piece? Why give a painting the mythological name if that is not what is represented? Could the subject of this painting be irrelevant because it is not the myth Courbet wanted to depict, but rather, did he aim to represent an underlying "real allegory," similar to his earlier paintings. Could the title not be indicative of

\footnotetext{
${ }^{126}$ Chu, "Unpainted Pictures," 134-135. Chu suggests that the Hippocrene Fountain painting was a companion piece to Courbet's large-scale The Artist's Studio. Her article examines fourteen unpainted works by Courbet and the possibility that many of them were either sister works to already completed paintings or satirical works.

${ }^{127}$ Courbet, Letters, 237-238. In Courbet's letter to Luquet, he mentions that both works were unintentionally destroyed in his studio. Luquet was an art dealer and an advocate for Courbet's work during the 1860's.

${ }^{128}$ Courbet, Letters, 237-238. This letter was written while Courbet was in Ornans around February-March 1864 and the version Chu includes in the translation of the letters is incomplete, according to her notes.

${ }^{129}$ Courbet, Letters, 237-238.
} 
the meaning of the painting, but rather a tactic used by the artist to claim innocence if accused of representing immorality.

In the same letter, Courbet also asked Haro if he would present the painting to the jury with his work works at the exhibition. ${ }^{130}$ Haro was a well-respected figure in the Paris art world and frequently exhibited his own works. Courbet must have been aware that his Venus and Psyche would have caused a stir, for in his letter to Haro he stated, "If you present it, that will inspire some respect in them (the jury) for this painting, which is very important to me." ${ }^{131}$ In April, Courbet received word that the painting was refused by the Salon for immoral reasons, to which he responded "It's prejudice on the part of the administration, for if this painting is immoral, one must close all the museums in Italy, France, and Spain."132 Courbet was never provided an official notice from any Salon representative that his painting was rejected, which had led him to doubt and question this conclusion of refusal. He wrote to Haro again on May 11:

I am very concerned about the fate of my painting. People write me that it stands neglected in a room of the Exhibition. If that's true, please have it taken to my atelier. I received no notice that the painting was refused at the instigation of the priests and the empress, and that the jury and M. Nieuwerkerke did what they could to have it accepted. I would be very obligated to you if you would be so kind as to let me know what is going on or at least what you know about this...I was refused regardless of the rules of the Exhibition and I am being portrayed to the public as an immoral man... What would prove to me that M. Nieuwerkerke did not agree with the refusal is that he did not inform me of the refusal and that he left that to those who followed orders and refused me. ${ }^{133}$

The obvious anxiety that Courbet had about submitting the painting suggests that the artist was aware Venus and Psyche must display some immoral action. And for Courbet to be so concerned about who informed him of his rejection is also suspicious; he had

\footnotetext{
${ }^{130}$ Courbet, Letters, 237-238.

${ }^{131}$ Courbet, Letters, 237-239.

132 Courbet, Letters, 240.

${ }^{133}$ Courbet, Letters, 240.
} 
been refused before from the Salon and was not bothered by who notified him of his rejection.

In the years leading up to the rejection of Venus and Psyche at the 1864 Salon, Courbet had been refused from the previous year's Salon for his Return from the Conference. The letter that followed its rejection, specifically the comment by Courbet that he painted it with the intention of being refused, defends the theory that he was willing to present a painting to the Salon with the objective of being refused. If one assumed this statement from the artist is truthful, then what would prevent Courbet from creating and submitting other paintings, such as Venus and Psyche which expressed such clear sexual connotations, with the goal of having them rejected from the Salon in order to stir up controversy? If his reasoning for creating certain paintings was not for public adoration or the honor of winning Salon medals, what purpose would an artist such as Courbet have to paint? If gaining distinction or awards was no longer the intention of his art, could these paintings be a forum for Courbet to express his personal philosophies and criticisms? Just as Chu and Fried have argued that Courbet's genre scenes and other paintings are anti-government, this paper considers his nude paintings to also have a political intent to them.

Courbet painted not one Venus and Psyche painting but rather five, which included two detailed studies of the two female figures; none of the five were commissioned for any particular patron. ${ }^{134}$ Of the three large-scale paintings, two were completed in 1864 and one in 1866. The two smaller studies were finished between 1863 and 1864; each study depicted one of the figures in the larger paintings. The composition in all three completed works remains the same, with only some minor changes within each painting.

\footnotetext{
${ }^{134}$ Although some alterations were made to appease buyers, the paintings were not commissioned.
} 
The first painting (fig. 16), completed in 1864, features the two female figures, a brunette Venus leaning over the blonde, sleeping Psyche. The former figure holds up with her left hand a dark fabric that drapes over the bed. This initial painting was the one mentioned in Courbet's letters to Luquet in March 1864, and was anticipated by the artist to be exhibited at that year's Salon. With no patron for the painting, Courbet was open to selling the work to any bidder. The catalogue raisonné of Courbet, completed in 1977, claims that this first painting was purchased for the collection of Georges Petit, although its current whereabouts are unknown. ${ }^{135}$

The second version, also from 1864 (fig. 17), includes a white cockatoo parrot perched on the left hand of Venus, placed there at the request of a later patron. In 1866, two years after the work's completion, a Parisian stockbroker by the name of Lepel-Cointet purchased Courbet's Covert of the Roedeer for 10,000 francs and verbally agreed to purchase this Venus and Psyche for 16,000 francs, on the condition that the artist alter the work slightly to dress the figure of Venus more modestly. ${ }^{136}$ Courbet obliged his client's request and made the modifications to the painting, only to have Lepel-Cointet refuse to follow through with the payment for this work, resulting in Courbet bringing his buyer to court over the painting. ${ }^{137}$ During the suit, it was revealed that although he had not paid Courbet, Lepel-Cointet had already considered the work to be in his possession and had agreed to sell the painting to another patron of the artist, Khalil Al-Bey, for 9,000 francs more than his arranged purchase price. ${ }^{138}$ Eventually, Courbet won the suit against Lepel-Cointet, who was ordered to pay the artist the agreed-upon price and to take

\footnotetext{
${ }^{135}$ Fernier, La Vie et l'œuvre, 210.

${ }^{136}$ Mack, 212.

${ }^{137}$ Mack, 213.

${ }^{138}$ Mack, 212.
} 
the painting. ${ }^{139}$ Seven or eight years later, Courbet came across this painting again, at this point the property of a different owner, who asked the artist to add the parrot now perched atop Venus' hand. ${ }^{140}$ While this in no way corresponded with the myth of the original title characters, Courbet consented, and then changed the title to the name it is commonly known as, The Awakening, because the addition of the bird had no connection to the myth represented by the original title. ${ }^{141}$ This painting's last known whereabouts, according to the catalogue raisonné, was in the collection of French art dealer Paul Durand-Ruel. However, it is believed to have been destroyed during World War II since no sightings of it have been noted since then. ${ }^{142}$

The third and slightly newer painting, finished in 1866 (fig. 18), is cropped in its dimensions in comparison to the 1864 versions. In it, Venus holds a rose by the stem, the blossom facing down with the petals dripping down onto the figure of Psyche, the first petal about to touch her face so the moment captured will soon be ruined by her waking. This, the only surviving Venus and Psyche painting, is currently in the collection of the Kunstmuseum in Bern, Switzerland. The unknown whereabouts of the earlier Venus and Psyche paintings make it difficult to examine and analyze the works in their entirety, but the 1866 painting delivers some insight into the works, despite its cropped size.

The two female figures within this work are clearly within a bedroom setting. Courbet's use of curvilinear lines emphasizes the arcs of the female figures, especially in the shoulders, breasts and waist. The full brushstrokes follow along the lines of the bodies, in a fluid motion

\footnotetext{
${ }^{139}$ Mack, 213. Mack mentions that Nieuwerkerke had previously visited the artist's studio and had agreed to purchase his Woman with a Parrot in early 1866, but was also interested in the Venus and Psyche painting, although no correspondence signifying this interest has been noted or discovered during my research.

140 Mack, 213.

141 Mack, 213.

142 The catalogue raisonné used and mentioned in this thesis is the only available at the current time, published by Robert Fernier in 1977. Courbet scholar Sarah Faunce is creating a new catalogue raisonné and web database of Courbet's work, however its publication date is unknown. For more information, please see the International Foundation for Art Research.
} 
that brings the viewer's eye around the forms. Thick, wide strokes that slightly vary in color can be viewed in the fabric, suggesting the various effects that light has on fabric. This implies that the fabric the Venus figure clasps in her hand is a luxurious material, something with a sheen that would reflect light. Alternating variants of blues and greys form the fabric, although a slight sense of stiffness similar to that of a taffeta fabric is communicated in the painting. ${ }^{143}$

The source of the light that illuminates the room appears to come from outside the scene on the left. Shadows cast underneath Psyche's breasts and face, as well as along the left arm of Venus and against the defined muscles in her body, indicate lighting from that direction.

Brightened areas of the rose, curtain, and the reflection from the earring are indicative of a light source within the painting.

Courbet's style of painting is very smooth and blended in this work, with each color intermingling with the neighboring hues, forming a flowing and unbroken depiction of color and space. His figures are not outlined, which has the effect of placing them within the space rather than making them appear as forms pasted within the setting. The gentle shading that he creates on the bodies depicts a true human figure, with changes in tone and coloration throughout instead of a flawless body; Courbet paints a realistic individual, not the idealized women seen in his contemporaries' nudes. Alexandre Cabanel's The Birth of Venus, 1863, (fig. 19) was submitted and accepted at the same Salon for which Courbet's Venus and Psyche was rejected, however, Cabanel's treatment of the female body differs greatly from Courbet's figure. In the nineteenthcentury ideal, the slight curves, porcelain-like skin tone, and petite figure of Cabanel's Venus are more reminiscent of an immortal figure in its perfection than any being Courbet created. Courbet's women are realistic and lifelike; he paints the figures life-size to convey a connection

${ }^{143}$ Taffeta was manufactured in France and one particular type called Taffeta Fleuret was a French taffeta that was fashionable during the early part of the nineteenth-century but much later it was frequently worn by French peasants. Louis Harmuth, Dictionary of Textiles, (New York: Fairchild Publishing Company, 1915), 185. 
between the viewer and the painting, suggesting that if these women would turn and step out of the canvas into reality, their shape and size would remain consistent.

A plush red curtain makes up the background of the painting, leaving the geographical location of the painting up for interpretation from the viewer. Only the wood bedpost is within view, and no other objects or details provide any part of a story for the viewer. Besides knowing that the setting is that of an interior living space, there are no indicators that would help to identify the external environment, which would assist in determining if the time period is within a mythological setting or a contemporary scene of Paris. The most descriptive factor of the painting is the title itself, for without it the scene would suggest the appearance of prostitutes within in a brothel to the nineteenth-century viewer.

The notion of the subject is homosexual behavior, which was thought to be common amongst prostitutes in brothels during the period, and is seen in this painting with the emphasis on the close proximity of the two women, as well as the lack of clothing on the figures, and the interior setting. ${ }^{144}$ Scenes that displayed graphic images of sexual encounters, such as those seen in the lithographs of Achille Devéria, (fig. 20) with depictions of women in sexual embraces with each other, are reminiscent of Courbet's representations. ${ }^{145}$ Devéria specialized in erotic prints, frequently depicting young women in intimate bedroom scenes, orgies, or other sexual acts. His The Girl Friends Discovered, (fig. 21) from 1833, depicts a scene much like Courbet's Venus and Psyche. The image shows a man with a lamp pulling back curtains to view two young women with their breasts exposed embracing each other while lying on a bed, and is comparable to Courbet's Venus and Psyche. The concept of discovering a person(s) in a vulnerable and sexual state, unaware of any other individuals nearby, corresponds with Courbet's

\footnotetext{
${ }^{144}$ Reilly, 159-171.

${ }^{145}$ Kosinski, 193.
} 
mythological scene, but the embrace of the female figures parallels his Sleepers, but with fewer garments.

Taking into account nineteenth-century society views about homosexual relationships among prostitutes and within brothels, and the lack of identifying details and objects in the painting, as well as Courbet's previous statement to Haro about the unimportance of subject matter, it would lead one to believe that that perhaps this painting was meant to convey something very different from what its title ascribes to it, Venus and Psyche.

Evident at first glance are the seductive and erotic tones that Courbet set forth with this painting. While Courbet said that the title was Venus in Jealous Pursuit of Psyche, he submitted this work to the Salon under the title Study of Women. This alteration of the title from mythological to nondescript brings about the question of why the artist would change the title to a more obscure, interpretative title. Was Courbet aware that this painting would be seen as risqué and controversial to the viewers of the Salon and to the jury as well?

On December 25, 1861, Courbet responded to a letter written from a group of students who had called upon him to open a school teaching Realism. ${ }^{146}$ In it, he addressed his theories on art:

...Art in painting should consist only of the representation of things that are visible and tangible to the artist...I hold that the artists of one century are totally incapable of representing the things of a preceding or subsequent century, in other words, of painting the past or the future. It is in this sense that I deny the possibility of historical art applied to the past... To go backward is to do nothing, to waste effort, to have neither understood nor profited from the lessons of the past. $^{147}$

Courbet had been honest about his dislike for artwork that represented historical events or interpretations; mythology was probably included in this in that its representation is of "lessons

\footnotetext{
146 Courbet, Letters, 203.

${ }^{147}$ Courbet, Letters, 203. Courbet stated that the arts cannot be learned through teaching but rather "every artist must be his own master."
} 
of the past." For Courbet to abandon his ideals that he strongly believed in and stressed to students and his peers would suggest that these paintings were not created with the intention of representing idealized mythological paintings, but rather the paintings carried a veiled implication. ${ }^{148}$

Perhaps the painting was submitted with the non-descript title so that the viewers could decipher the work for themselves, offering the idea that the work was individual to each person. ${ }^{149}$ Courbet's admission to Luquet in the February-March 1864 letter that it was "painted in a manner that you have never seen me do" suggests that this nude painting is unlike any other he had previously created. ${ }^{150}$ Courbet's The Bathers, and Girl with White Stockings, c. 1861, (fig. 22) and Reclining Nude, 1862, (fig. 23) all presented female figures in some state of undress, demonstrating that the artist was not unfamiliar with illustrating the nude female body, but something about this particular painting makes it unusual and distinct from the others.

The setting for Venus in Jealous Pursuit of Psyche is one that Courbet often depicted in his nude paintings - a bedroom. One woman lies asleep on a bed, ruffled sheets covering her genitalia while the rest of her body and her breasts are exposed. The placement of her body and her pose is almost identical to the figure in Courbet's later 1866 painting Woman with a Parrot (fig. 7). This pose, similar to the Vallou de Villeneuve photograph (fig. 11), is one that Courbet used often in his nude paintings, and is seen in at least three other works as well. ${ }^{151}$ The blonde haired woman represents the figure of Psyche, her slumber indicative of her identity in that her

\footnotetext{
148 Courbet, Letters, 203-205.

149 Chu, "Uneasy Nudity," 38.

${ }^{150}$ Courbet, Letters, 237.

${ }^{151}$ Other paintings by Courbet that share the same reclining nude figure, laying upon disheveled sheets are his Reclining Nude, 1862, Reclining Woman, 1865-1866, and The Sleepers, 1866. Within these three paintings, and the two listed in the text, the figures all have the same body structure and positioning of the bent and crossed knees, and the hips of all the figures are turned, with a profile or three-quarter view of the figure's face.
} 
unconsciousness is a theme both within in this painting and the myth that describes her tale. ${ }^{152}$ The dark-haired figure, whose features are sharper and larger, is the Roman goddess Venus, who is perched at the edge of the bed. Venus leans over the legs of Psyche, her right hand clutching a bed sheet to her chest while her left hand holds up the canopy atop the four post bed. The goddess stares intently at the sleeping Psyche, who is blissfully unaware of the deity who has entered her bedchamber.

One detail that is discernible within the painting, and also replicated within the other versions, is the muscular features of the figure of Venus. Although the figure represented is supposed to be female, the muscular structure of the body as well as her still, unrealistic breasts emphasize features veering more to the stereotypically masculine in the figure. This difference in hair color between dark and light suggests roles of active and passive from the figures. Courbet's decision to depict the brunette figure with underarm hair, while realistically accurate, was considered taboo; while it was common for the women to have such features, artistic depictions, especially ones of immortal goddesses, did not show this feature. ${ }^{153}$

In Maura Reilly's dissertation, she examines the concept and portrayal of lesbianism throughout a number of Courbet's nudes from the eyes of the nineteenth-century viewer. This idea of a blonde-brunette polarity, Reilly claims, was a signifier in imagery of lesbianism, which Courbet exemplifies in this painting of the two female figures. ${ }^{154}$ This use of opposing hair colors was employed to place the women into male and female categories, with the darker haired female considered as "active", the counterpart to the "passive" blonde character; therefore attempting to skew the representation of two women into opposing characters, a tactic to distort

\footnotetext{
152 Edith Hamilton, Mythology: Timeless Tales of Gods and Heros, (New York: Grand Central Publishing, 1942), 121-134.

153 This was not the first female figure that Courbet painted with underarm hair. He also painted his Woman in the Waves, 1866, with a similar feature. Reilly, 194.

154 Reilly, 116.
} 
gender roles in order to make a lesbian relationship appear as a more heterosexual one, and consequently less intimidating to the public. ${ }^{155}$

Parallel to other Roman myths, the story of Cupid and Psyche focuses on the amorous lives of immortals and their affairs with mortals. The scene that Courbet presents is not of the title characters within the myth, but rather the jaundiced and covetous tactics by the goddess Venus. The Latin writer Apuleius in the second century A.D. tells the story of the two lovers. The maiden Psyche was the youngest of three daughters and known for her beauty and popularity amongst men. Many men abandoned their idolatry of the goddess Venus to exalt and praise the mortal girl. Venus, angry at the neglect of her worshippers, visited Psyche while she slept in order to examine the woman who caused her followers to desert her. After seeking out Psyche while she slumbered, Venus commanded her son, Cupid, to inflict her with one of his arrows, therefore bewitching Psyche into falling in love with and marrying a mortal so that she would no longer be a competitor for the affections of her worshippers. While following his mother's orders, Cupid descended upon the sleeping Psyche, viewed her splendor, became captivated by her beauty, and fell in love with her. Cupid then tricked the mortal into becoming his wife, and taking her away to live with him, all the while concealing his identity from her.

Psyche, unaware that the god of love was her husband, confided this information to her sisters. Upon learning this and believing their Psyche's husband was a hideous monster serpent, the sisters convinced Psyche to sneak out of bed one night while Cupid slept and slay him. In the moments before Psyche was about to kill her husband, she saw that he was not the creature she thought, but rather a god. At this moment, a few drops of oil from the lamp she carried fell onto

\footnotetext{
${ }^{155}$ Reilly, 120. Reilly claims this tactic began in the eighteenth-century, generally seen in imagery depicting women with their African or Oriental maid-servants within toilette or bathing representations. As time went on, this was diluted into imagery of two white women, but the opposing hair colors were still a representation of the male and female within the painting.
} 
Cupid's shoulder, awakening him and causing him to immediately flee from his wife, running to Venus. Furious at the insolence of her son, for his marriage to Psyche, Venus demanded that Psyche complete various tasks in order to spare her life, but with the assistance from others, she completed them all. At this point, Cupid became aware that his mother was requiring his wife to complete these tasks, and after some pleading, Juno agreed to make Psyche a goddess, thereby ending the persecution by Venus. ${ }^{156}$

The title of Courbet's painting, Venus and Psyche, relates to the figures depicted within the composition; however the scene that he chose to illustrate has no correlation to the myth of Psyche. Within the twenty-year span before the artist created this work and its three variations, there was a resurgence of interest in the myth of Cupid and Psyche, with many poems being written in Paris and elsewhere in Europe. One such narrative poem was that by Victor de Laprade, 1812-1883. His poem Psyche, was published in 1841, however Laprade's strongly religious background makes it unlikely that he would have included such an erotic scene within his poem. ${ }^{157}$ Elizabeth Barrett Browning, 1806-1861, wrote a popular text paraphrasing Apuleuis' story of the lovers. ${ }^{158}$ The dramatic arts also saw a revival of Psyche-related theatrical productions. The comic opera Psyche, by Ambroise Thomas, 1811-1896, was first performed on January 26, 1857 in Paris and was revived twenty years later. Another theatrical performance that featured the myth was by Jean-Pierre-Félicien Mallefille, 1813-1868, which also bears the title Psyche and was performed in Paris in $1845 .{ }^{159}$ Dictionaries of mythological subjects were also being produced shortly before Courbet began creating his paintings, contributing to the

\footnotetext{
${ }^{156}$ For a more detailed account of the myth, see Hamilton, 121-134.

${ }^{157}$ Pierre Marique, "Victor de Laprade," Catholic Encyclopedia, December 22, 2013, accessed December 22, 2013, http://www.newadvent.org/cathen/09001a.htm.

${ }^{158}$ Browning's works were written in 1845; however they were not published until 1862, one year after her death. Her work was a lyrical drama that went into detail about the myth of Cupid and Psyche.

${ }^{159}$ The American Annual Cyclopedia and Register of Important Events of the Year 1868, vol. VIII, New York: D. Appleton and Company, 1871, 600.
} 
knowledge that Parisians had of the mythological story. This fascination with the lovers was one shared by both the public and royalty.

Examination of the interior decoration from the Napoleonic era through the July Monarchy, from 1799 to the mid-1850's, exhibits a variety of depictions of the immortal and his beloved. ${ }^{160}$ In describing the relation between the myth and the public, the French scholar Louis de Jaucourt, 1704-1779, stated, "I know they are fanciful figures, but the role they play in the writing of ancient poets and the frequent allusions by modern poets have almost made them real for us. Our eyes are so familiar with them that we have trouble thinking of them as imaginary beings." "161 This connection by Jaucourt emphasizes the relationship that society had with these images of mythological beings - these figures were relatable and in a sense, realistic. This association with the characters as real persons, not fables, proposes the theory that perhaps Courbet was not aiming to represent mythical beings, but rather actual depictions of persons in society.

Browsing through the representations of the myth of Cupid and Psyche displayed throughout art history, it is significant to note the portrayals of the story that are most often illustrated and contrast how Courbet distinguished his version from those. Most depictions show Cupid and Psyche together, either in passionate embrace, as seen in Antonio Canova's sculpture Psyche Revived by Cupid's Kiss, 1793 (fig. 24) or shown as unaware of the other figure, such as

\footnotetext{
160 Louis de Jaucourt, "Mythology," The Encyclopedia of Diderot \& d'Alembert Collaborative Translation Project. Translated by Nelly S. Hoyt and Thomas Cassirer. (Ann Arbor: Michigan Publishing, University of Michigan Library, 2003), http://hdl.handle.net/2027/spo.did2222.0000.162 (accessed December 10, 2013).

161 De Jaucourt, "Mythology." Jaucourt's quote is not a direct reference to the myth of Cupid and Psyche, but rather mythology as a whole during this period. This explanation expressed the connection that the viewer had with these myths and the figures included within them, likening them to being individuals rather than imaginary beings from stories.
} 
François Gérard's Psyche Receiving Cupid's First Kiss, 1798 (fig. 25). ${ }^{162}$ While some depictions do stray from these two interpretations, most fall within one of these two categories and it appears that none actually represent the scene which Courbet chose to illustrate.

Venus' role between Cupid and Psyche in visual versions illustrating this myth is minimal, with most artists choosing to emphasize the romantic aspects of the heterosexual couple. If Venus is included, she is generally illustrated assigning the tasks she orders Psyche to perform, which differs from the intimate setting that Courbet depicts. The placement of the characters in the bedroom setting appears to be more like the scene of Psyche discovering the identity of her husband, in which hot oil drops from her lamp, landing on Cupid, waking him. Perhaps this was the original intention of Courbet in this work, with the composition set up in such a manner that by easily changing the gender of the sleeping figure to male and altering the rose and petals to an oil lamp, this scene would be easier for the viewer to distinguish. Courbet did not often paint two heterosexual lovers together, the most significant male and female figures within any sort of romantic embrace is depicted within The Artist's Studio, but even those lovers do not seem to share the same tension and emotion suggested by Courbet's women, as there is no nude physical contact between the male and female lovers being depicted.

Courbet's figures of Psyche and Venus are placed within a bedroom setting, unlike other interpretations of the myth. One large variation between Courbet's painting and other artists' depictions is that the figure of Venus is normally not represented; instead the character of Cupid is usually shown in a bedroom scene with Psyche. Such representations can be seen in JacquesLouis David's Cupid and Psyche, 1817, (fig. 26) and François Picot's Cupid and Psyche, c.

\footnotetext{
${ }^{162}$ Canova and Gérard's works were, and still are, housed in the Musée du Louvre's collection. While created before Courbet's time in Paris, Gérard's painting joined the collection in 1822 and Canova's sculpture was accessioned in 1824.
} 
1817, (fig. 27). ${ }^{163}$ Could these representations have been Courbet's inspiration to complete his Venus and Psyche works? Why would he choose to depict one of the main and one of the secondary characters, in a scene that does not seem to exist in any accounts of the tale? For Courbet to have strayed from the myth, and to represent such an obscure scene, would suggest that the artist had other intentions with this painting, and perhaps the title became a disguise for the painting's true meaning.

The public was informed and aware of the story of the lovers and the role that Venus had, however, depictions of this scene are unknown and its illustration differs from that of Courbet's contemporaries. Few elements in Courbet's painting match those of his predecessors: the figure of Psyche is fast asleep in her bedroom, vulnerable and exposed, similar to the Renaissance sleeping nudes of the past, with their idealized bodies gracefully slumbering. Courbet strays from the picturesque and idealized world his predecessors had represented the nude female in, and instead provided a modern interpretation of the fable of Psyche by exhibiting a voluptuous and fleshy body in a bedroom. This painting was not the first Courbet had completed representing a scene from this myth involving Psyche, although it is unknown if the other painting, Amor and Psyche, shared the realistic composition and intimate setting.

In 1860, Courbet wrote to Champfleury and stated that he wished to create a piece that would criticize the controversial Franco-Austrian war of 1859. The work, to be titled Cemetery at Solferino (fig. 28), was never completed, but plans for the painting still exist and drawings

\footnotetext{
163 Picot's artwork joined the collection at the Louvre in 1822, so Courbet likely viewed the painting at this institution. David's painting, while currently housed in Cleveland, Ohio, was originally a gift from the artist to Louis Nicolas Philippe Auguste, the comte de Forbin, 1779-1841, who was a curator at the Louvre beginning in 1816. Provenance of the painting, provided by the Cleveland Museum of Art, indicates that after being the property of Auguste, it was maintained in a private collection in Paris, then was purchased by Eugene Thaw, b. 1927, and moved to the United States.
} 
based on these have been created to illustrate how the painting might have appeared. ${ }^{164}$ Courbet wrote:

Now for something quite risqué: I just finished Amor and Psyche, which you are familiar with, with some minor additions. I also feel like doing a painting for them about the war, with either the cemetery at Solferino or another carnage in the middle ground, and in the foreground two of their soldiers who excel in that kind of exercise, a Turco and a Zouave. The two wild beasts will charge like two vampires, carrying away Austrian heads on the points of their bayonets, together with their spoils - all this at dusk, the Negro's teeth will light up the countryside. This will make two figure paintings, the first will be for the Academy, the second for the warriors. I confess, my dear friend, that I have such hatred for French institutions that, in spite of my poverty, I cannot give up the struggle and take governments seriously. ${ }^{165}$

This painting would have looked similar to the caricatures that were being frequently produced during this time and would have been aimed at Napoleon III's attack during the Second War of Italian Independence in 1859 , a controversial military mission. ${ }^{166}$ This work was to shock and condemn the actions of the military, while the Amor and Psyche painting was to be an attack on the Academy. ${ }^{167}$ The military painting was never completed, however, the mythological painting was. Unfortunately, Amor and Psyche's current whereabouts are unknown and there are suspicions that it was destroyed, but this raises the question of what similarities would have been shared between this painting and Venus and Psyche? It was common for Courbet to reuse models and scenes within his paintings, and the artist depicted most women in either an interior bedroom setting, or in a wooded forest area. It would not be unusual for him to slightly alter the scene presented in Amor and Psyche to have created the new Venus and Psyche.

\footnotetext{
${ }^{164}$ Chu, "Unpainted Pictures," 140.

165 Courbet, Letters, 185. Chu notes in an earlier letter to Armand Gautier in early November 1860 that Amor and Psyche is not in existence today. This painting was supposedly a copy or influenced by a work of the same title the Montpellier artist Magnol that was completed in 1857. Courbet finished this painting while staying with Bruyas. In the letter to Gautier, Courbet states that the painting will "be a biting mockery of the gentleman of the grand art of painting and thereby have a serious side." Courbet, 182.

166 Chu, "Unpainted Pictures," 136-137.

${ }^{167}$ Courbet, Letters, 185. Amor, or Eros, and Cupid are the same figures in mythology; Amor being the Greek name for the god of love and Cupid being the Roman name.
} 
Taking into account the date of this letter, December 1861, and Courbet's first mention of Venus and Psyche in March 1864, it would suggest that Courbet's artistic aim would have not changed drastically. It was even suggested by Castagnary that most of Courbet's paintings were planned far in advance of their completion, and that the artist took several years to mull over paintings before executing them. ${ }^{168}$ There is no evidence to support that Courbet had been preparing to complete Venus and Psyche before 1864, as no mention of the painting can be found before 1864, however, Amor and Psyche, which the artist had admitted had been an attack on the Academy in 1860, introduces the concept that Courbet would be willing to represent mythological figures, something he spoke against, in order to disguise a condemnation.

After the completion of the 1864 Venus and Psyche, Courbet wrote to Proudhon in December of that year stating that he was making a counterpart painting; only this would have a much different subject matter from the mythology-based piece. ${ }^{169}$ This work would have been influenced by Proudhon's current philosophical writings and negative feelings towards feminism, which were expressed in his book La Pornacratie. In this text, Proudhon argued that a woman's place was in the home and he criticized the Second Empire for its immorality and lack of ethics and domesticity. ${ }^{170}$ Courbet's painting Woman Kneading (fig. 29) depicts a woman kneading dough in a kitchen with several children around her. Courbet's admission that this work of a housewife baking as the counterpart to Venus and Psyche would have shown the contrast between the two works: one virtuous woman playing into her role as wife and mother versus two sensual, carnal women seen in a lascivious and intimate setting that exudes the

\footnotetext{
${ }^{168}$ Chu, "Unpainted Pictures," 134.

169 Courbet, Letters, 251.

${ }^{170}$ Pierre-Joseph Proudhon, Du Principe de l'art et de destination sociale, (Paris: Garnier, 1865), 262. Translation included in Chu, 1992, 41.
} 
opposite role of sexuality and harlotry, thus dismissing any suggestion of the mythological title. While Courbet did not clearly state that the implication of this work is that of prostitution and illicit actions, the acknowledgement of the other work as a companion and counterpart could lend credence to the idea that the "mythological" work is that of a forbidden nature. ${ }^{171}$

In the first title that Courbet gives to Venus and Psyche, on March 3, 1864, he lists the title as Venus in Jealous Pursuit of Psyche, which he said was a "high-flown title" and he had resolved to call the work Study of Women for the Salon catalog. ${ }^{172}$ The decision to change the title of the painting may seem to be insignificant; however, Courbet had recently made a statement about jealousy, which corresponds with the notion that this painting suggests political criticism.

In 1863, Courbet wrote to Proudhon, who was in the middle of compiling his treatise on art, Du Principe de l'Art et de sa Destination Sociale. Courbet included many of his thoughts about art, politics, and morality, one of which referenced jealousy. "The extreme love that one may feel for a woman is a sickness. It absorbs the thinking faculties, makes man jealous and worse than an animal. Jealousy is misplaced pride." ${ }^{173}$ Could this mention of jealousy in the title of Courbet's overtly sexual Venus in Jealous Pursuit of Psyche be an attack against prideful and egotistical government officials? Napoleon III was often jealous over the actions of other ruling nations and also aspired to fill the immense footsteps of his uncle, Napoleon I. ${ }^{174}$ Napoleon III also wanted to solidify his authority, had fears of illegitimacy and desired to be associated with the ancient Holy Roman Empire to justify his place on the throne of France. ${ }^{175}$

\footnotetext{
${ }^{171}$ Chu, "Uneasy Nudity," 42.

172 Courbet, Letters, 238.

${ }^{173}$ Courbet, Letters, 231

${ }^{174}$ Boime, Art in the Age of Civil Struggle, 584.

${ }^{175}$ Boime, Art in the Age of Civil Struggle, 584-585. Boime claims that Napoleon III's insecurity about his legitimacy to the throne is what propelled him to seek out artists that would create propagandistic paintings, casting
} 
This misplaced pride and jealousy that Courbet references in his correspondence with the young students could have become motivation for the artist to complete Venus in Jealous Pursuit of Psyche.

As mentioned in chapter four, Nieuwerkerke, who was known to have had a tumultuous relationship with Courbet, had carried on an affair with Princess Mathilde for many years. Her connections were one of the reasons he was placed in the powerful position he was. According to the beliefs of Proudhon, the philosopher with whom Courbet sought connections, the illicit affair between the princess and the Superintendent would have been highly frowned upon. In following Proudhon's theories precisely, one could even argue that the immorality of Mathilde's infidelity to her husband when they were married and her abandonment of marital values would have categorized her as a fille de joie; a prostitute. Proudhon's theories that women could only be one of two things, a housewife or a harlot, would have branded Mathilde as the latter, and the association between prostitution and lesbianism was the standard response for people in nineteenth-century Paris. With Courbet striving to attach his name to Proudhon and his theories, to create a painting based on these ideals, and do so in a way that would attack the French government, could legitimize the artist's attachment to the popular philosopher. Apart from the aforementioned suggestion of homosexuality and immorality, Courbet indicated a Proudhonian connection with details relating to Mathilde in his 1866 Venus and Psyche painting. This signified an attack not only on the government and princess, but also on her lover and the frequent adversary of Courbet, Nieuwerkerke.

In the photographs and illustrations of the Princess, she is rarely without her famous jewels, including the Tudor Rose brooch. This large diamond-encrusted rose brooch, which was 
created in 1855, was the most prized piece in Princess Mathilde's collection (fig. 30). ${ }^{176}$ Apart from its obvious aesthetic appeal to the princess, the rose is also an attribute of the Roman goddess Venus, the goddess of love and beauty.

Most depictions of Venus show her with a scallop shell or pearls, which are a symbol of the goddess. In Courbet's 1866 painting, there are no pearls or shells to be found, but rather the female Venus figure wears red, perhaps ruby, drop earrings. Could this be a gesture to identify the Princess, who was known not only for her ex-husband's wealth of jewels but also for the ones that she refused to return after she deserted their marriage? The rose that Courbet's Venus holds is a symbol of the goddess and her beauty. ${ }^{177}$ The decision to represent the flower with the petals falling down suggests a lack of beauty. This rose is pink, while most depictions of roses that accompany Venus are white or red. The inclusion of the oversized rose blossom, while following with the iconography of Venus, could also suggest the identification of the figure not as a model, but as Mathilde, since she was known for the oversized rose brooch. Courbet's reconstruction of the brooch from jewelry into an object that would appear to fit within this painting's ostensible iconography reveals his representation of the princess.

The physical characteristics of Courbet's figure do not follow the standard representations of Venus. The darker hair he painted is not normally associated with the figure, and most contemporary depictions of the goddesses showed her with lighter locks. ${ }^{178}$ Close examination of Courbet's painting shows that the hair he depicted is a dark shade, almost ebony,

\footnotetext{
176 This brooch was created in 1855 for the Princess and sold in a 2004 auction at Christie's in New York for \$701.900. "Formerly the Property of Princess Mathilde (1820-1904) the Tudor Rose a Magnificent Antique Diamond Corsage Brooch, by Theodore Fester," Christie's, August 24, 2013, accessed August 24, 2013, http://www.christies.com/lotfinder/formerly-the-property-of-princessmathilde/4350160/lot/lot_details.aspx?from=searchresults\&intObjectID=4350160\&sid=053e69c5-c9a9-4a06-98f7$6 \mathrm{~d} 8 \mathrm{f} 9 \mathrm{f} 4517 \mathrm{~d} 0$.

177 James Hall, Dictionary of Subjects and Symbols in Art, New York: Harper \& Row, 268.

${ }_{178}$ Popular depictions of the Venus figure with blonde hair include Sandro Botticelli's The Birth of Venus, 14831485, Jacopo Tintoretto's Venus, Mars, and Vulcan, c. 1551, and Peter Paul Rubens' Venus at a Mirror, c.1615.
} 
the same shade as Mathilde's. With the profile of the figure apparent to the viewer, contrasting the profile of the goddess to that of the Princess shows that the figures do have some resemblance within the facial structure (fig. 31). The straightness of the nose, the slight flare of the nostrils, the sharp indentation between the lips and the chin of the figure, and the plushness of the skin under the chin all reflect details seen in Mathilde's portrait.

Taking all these factors into consideration, could it be that the model for the piece was not one that Courbet ordinarily used but that of his unstated rival, Nieuwerkerke's mistress? As her identity has not yet been discovered by art historians, one could theorize the model was Mathilde. Perhaps Courbet's decision to use the Princess as a model was something that he thought no viewer would distinguish, but then he chose to add details to the 1866 painting that would identify her as such. Courbet often used figures from his life as models and the identities of most were distinguishable, however the model for Venus in this particular painting has not been identified yet. The opportunity to disguise the painting as mythological due to its title, and the artist's history of using the same models in his works, could have provided him with the protection to insert his foe's companion into the piece, taking aim at his enemy.

At the time the original version had been completed in 1864, Courbet and Nieuwerkerke were not on amiable terms, partly due to Courbet's paintings being rejected from both the Salon and the Salon des Refusés just a few months prior. The 1866 version of Venus and Psyche, which contains the specific rose feature, was completed in a year during which Courbet was at odds with Nieuwerkerke, both because of the disagreement about the of a painting, but also for being overlooked for the Legion of Honor. Courbet was rumored to have been on the short list for this particular award, however, his dispute with Nieuwerkerke cost him any opportunity of 
being awarded this accolade. ${ }^{179}$ In the August 11, 1866 newsmagazine Monde illustré, an article by Charles Yriarte was published that stated:

If we wished to engage in some dangerous gossip, we could relate what happened between Courbet and the superintendent of the Fine Arts Administration...M. Courbet is supposed to have ruffled the administration's feathers, which will probably cost him his cross on August 15. People will tell me that, if M. Courbet has talent, a social matter (or perhaps we should say 'sociable,' which would be closer to the truth), should not prevent him from getting his reward...."180

Four years later Courbet was offered the Legion of Honor by Napoleon III, but publicly refused the medal, further damaging his relationship with the government, but strengthening the public opinion of those who disliked the current regime. Courbet's letter of rejection of the medal was published in June 1870, the last paragraph reading,

I am fifty years old and I have always lived in freedom. Let me end my life as a free man. When I am dead, they must be able to say of me, 'That one never belonged to any school, to any church, to any institution, to any academy, and, above all, to any regime except the regime of freedom.",181

\footnotetext{
${ }^{179}$ Courbet, Letters, 297.

${ }^{180}$ Courbet, Letters, 297

${ }^{181}$ Courbet, Letters, 378-381.
} 


\section{Conclusion}

Castagnary believed that Courbet's aim was to provide political commentary with these depictions of lesbianism; he wrote about Venus and Psyche, aiming his comments at the Parisian bourgeoisie, "You who tolerate the Empire take care, here are the women that the Empire is in the process of forming." 182 Since Mathilde was a relative of Napoleon III, and also in an adulterous relationship with a high government official, it could be argued that she would fit the description of a woman that the Empire is "forming".

Courbet's penchant for controversy made him well-known throughout Paris and the art world in the nineteenth-century, although at times his desire to be provocative contradicted his aspiration for exposure of his art. The theory that many of Courbet's paintings present allegorical themes that go beyond the titles and the subject matter specifically represented has been discussed by previous scholars; however, this concept has never been explicitly examined within his Venus and Psyche paintings until now. Considering Courbet's political and philosophical affiliations, as well as the clear difficulty he had with government individuals within the Second Empire regime, it is important to view not just the argued allegorical paintings from the artist as an attack on the government, but to look at all of his works through this lens. Beginning with his After Dinner at Ornans and The Stonebreakers, through The Artist's Studio, The Bathers, and his nude paintings of the 1860's ending with Venus in Jealous Pursuit of Psyche, Courbet's figurative paintings portray his personal commentary on society, politics and religion.

While the mythological and nude paintings that Courbet created have been previously examined solely as the fables they represent, the artist's history of underlying themes within his paintings has not been explored in relation to these works. Venus and Psyche is one such

\footnotetext{
182 Fried, 206.
} 
painting that has a history behind it of personal vendettas, uncanonical mythological representations and philosophical theories about society. For Courbet, painting was not merely a profession, but a representation of himself and his ideas, within which he would often portray events in his life. Courbet's connection to Proudhon and his theories, along with the poor rapport Courbet had with the government and Nieuwerkerke, provides a different interpretation of Venus in Jealous Pursuit of Psyche than the title suggests; from mythological to philosophical and personal. 


\section{ILLUSTRATIONS}

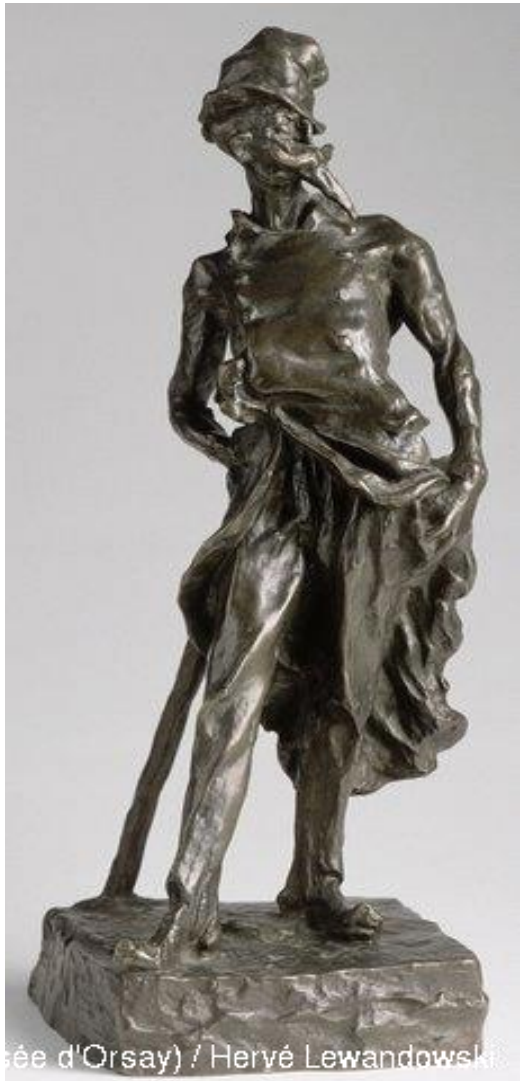

Figure 1: Honoré Daumier, Ratapoil, c. 1851, Statuette, patinated bronze, Musée d'Orsay, Paris.

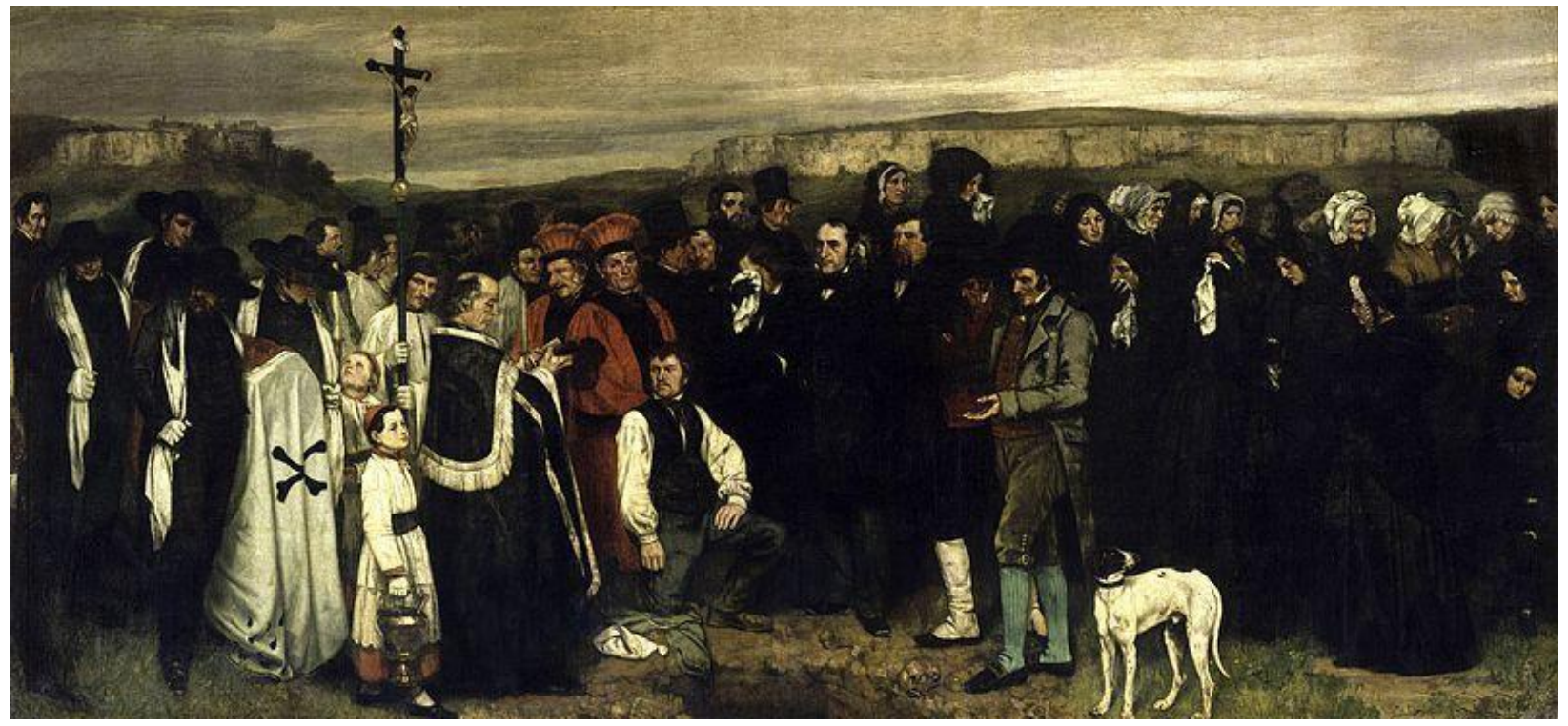

Figure 2: Gustave Courbet, Burial at Ornans, 1849-1850, oil on canvas, Musée d'Orsay, Paris. 


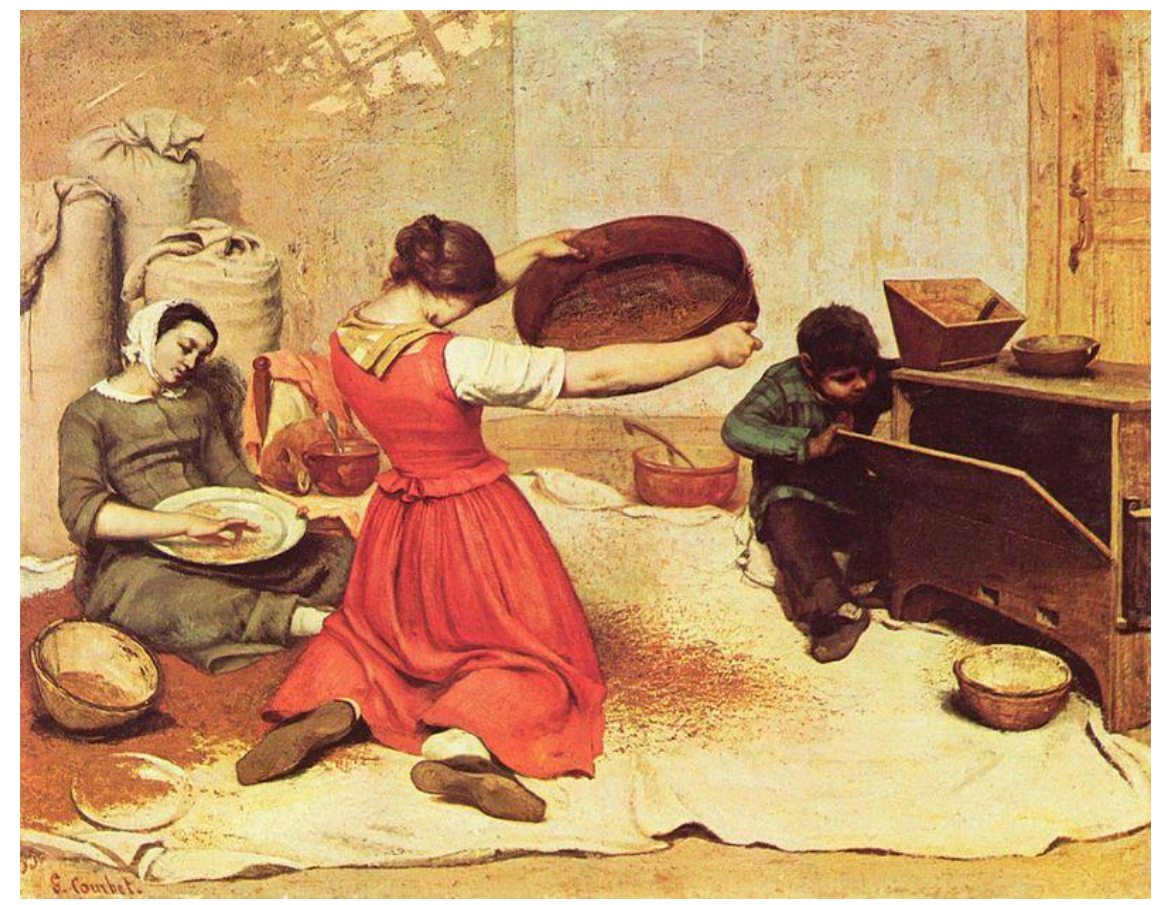

Figure 3: Gustave Courbet, The Wheat Sifters, 1853-1854, oil on canvas, Musée des Beaux-Arts de Nantes.

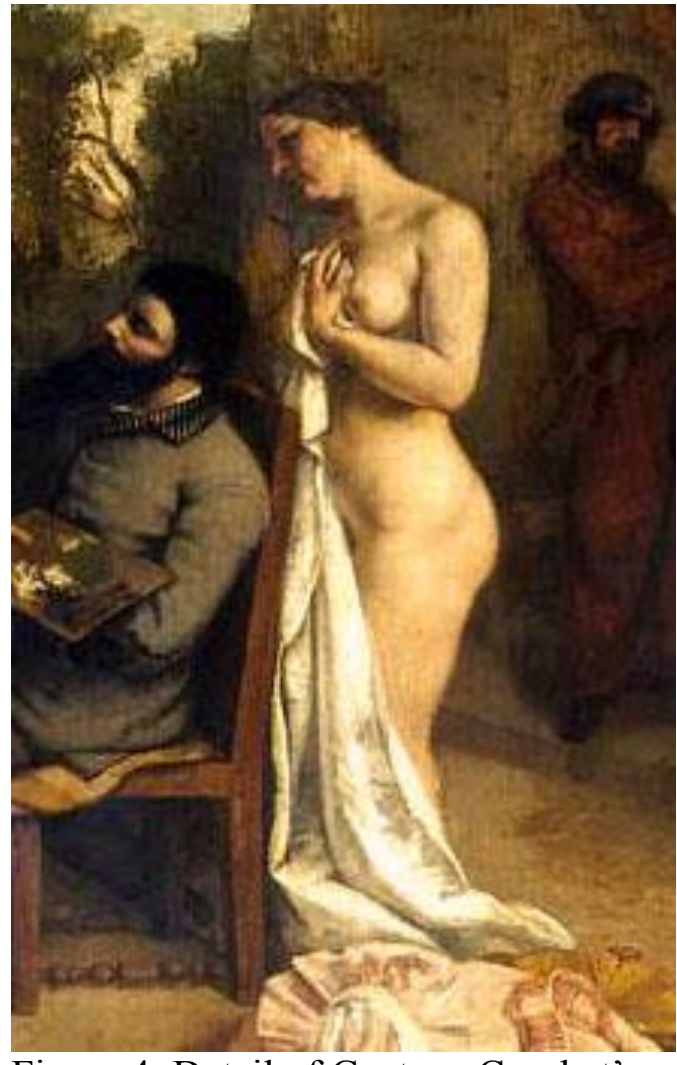

Figure 4: Detail of Gustave Courbet's The Artist's Studio, 1849-1850, oil on canvas, Musée d'Orsay, Paris.

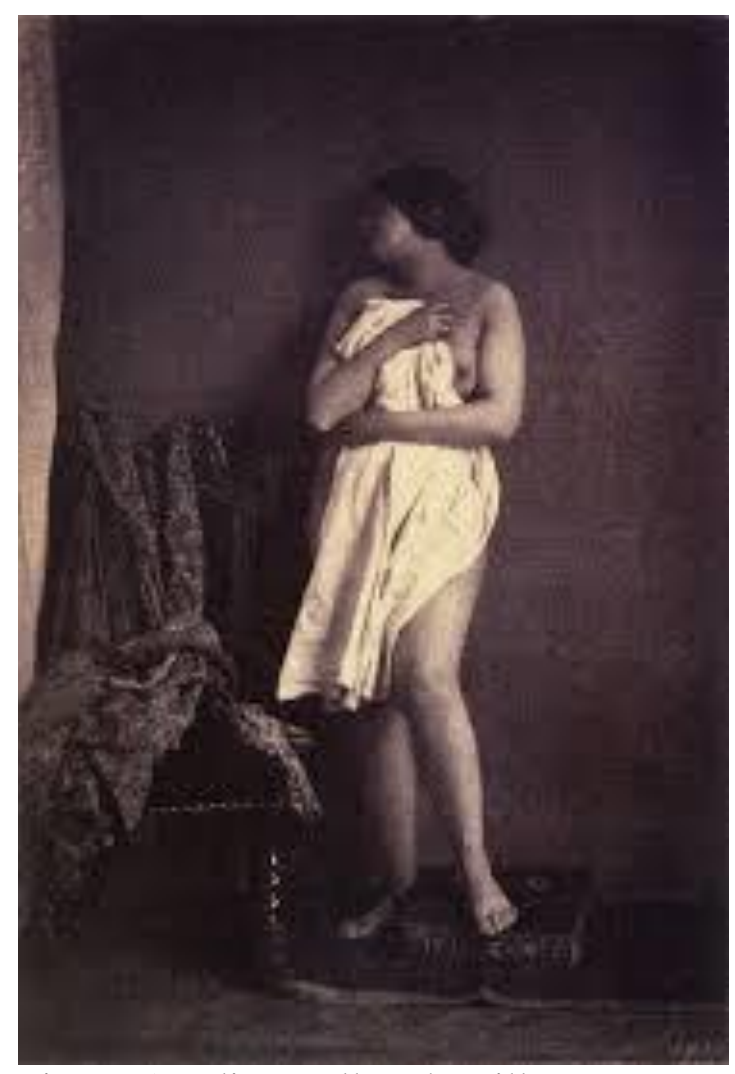

Figure 5: Julien Vallou de Villeneuve,

Nude Study, daguerreotype, registered 1853, Bibliothèque Nationale de France, Paris. 


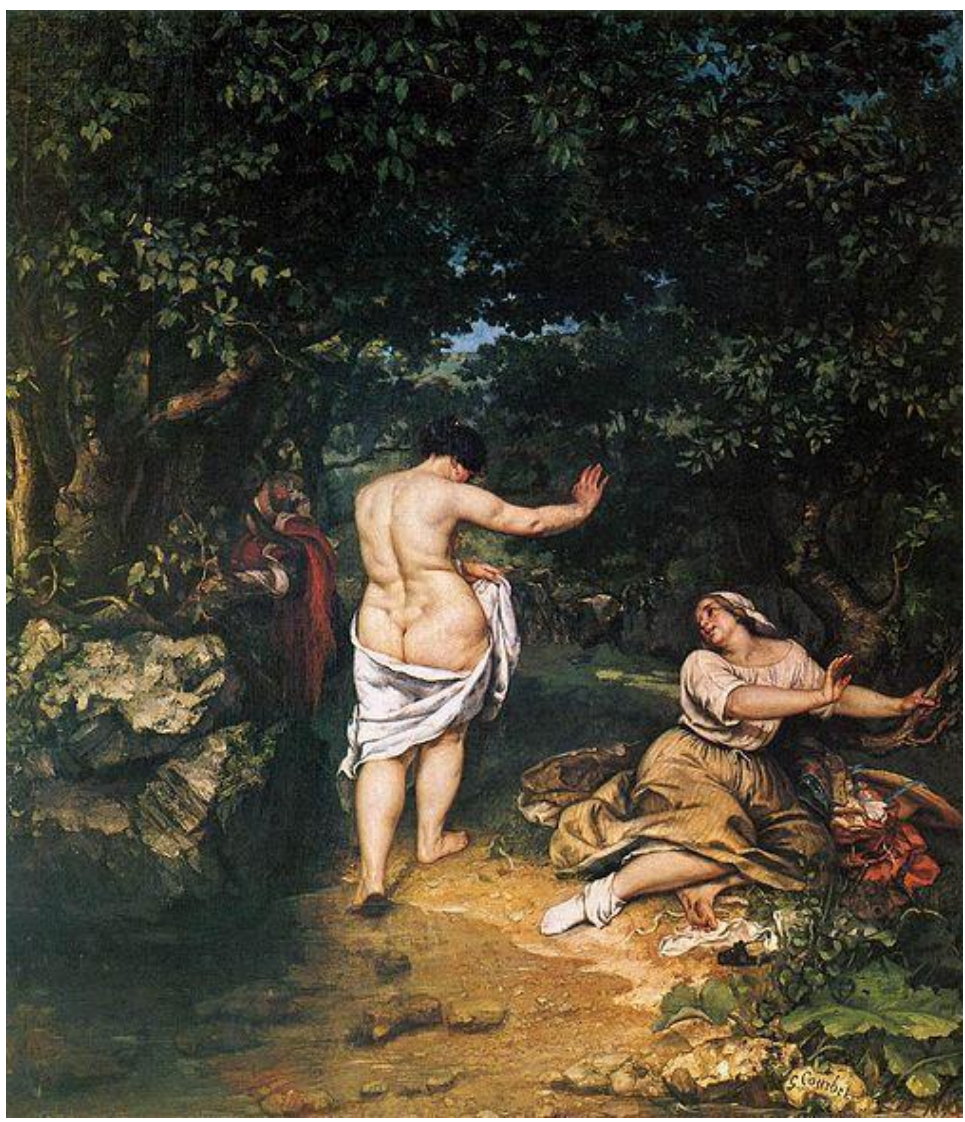

Figure 6: Gustave Courbet, The Bathers, 1853, oil on canvas, Musée Fabre, Montpellier.

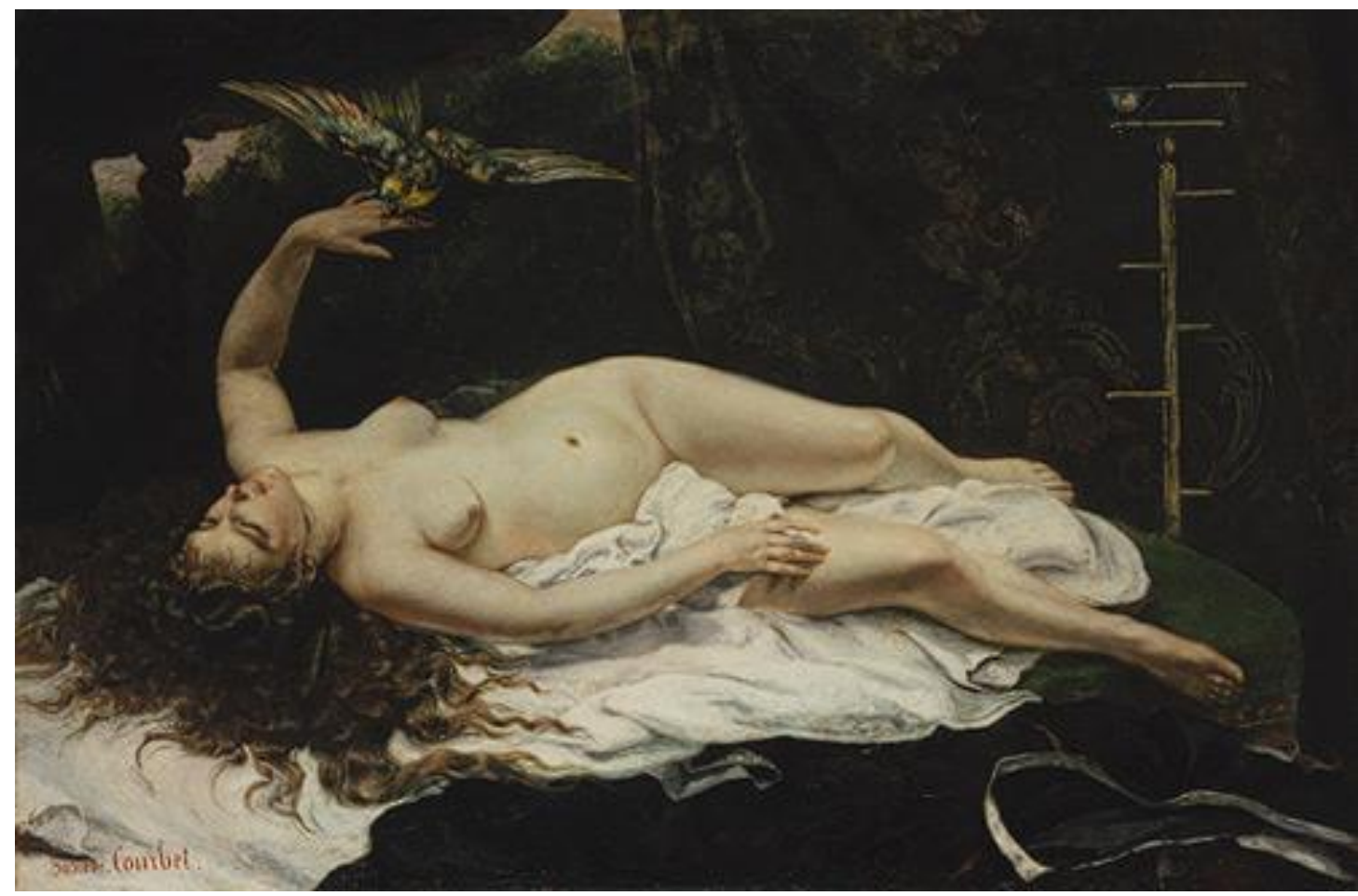

Figure 7: Gustave Courbet, Woman with a Parrot, 1866, oil on canvas, Metropolitan Museum of Art, New York. 


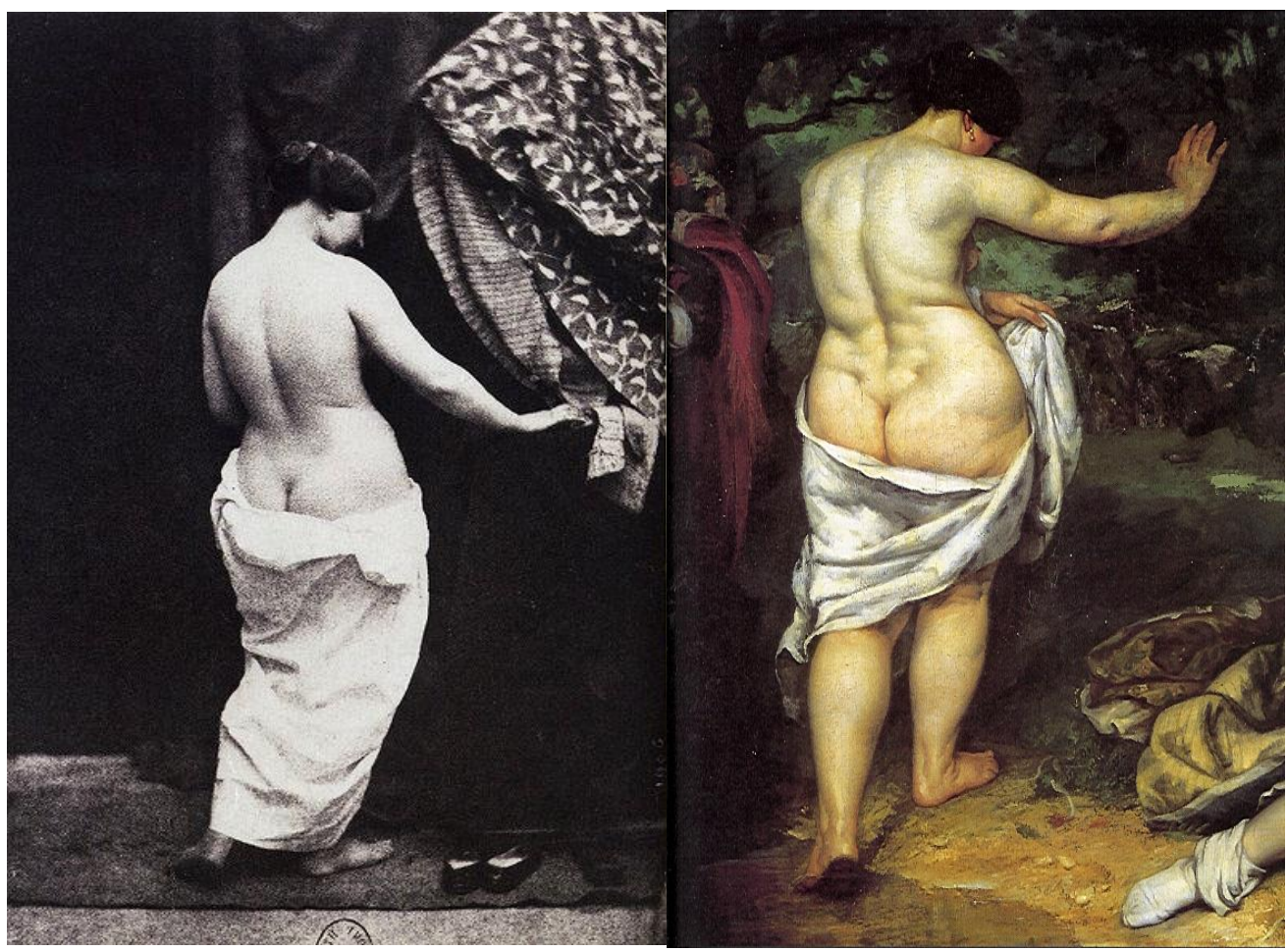

Figure 8: Comparison between Julien Vallou de Villeneuve's Standing Nude, registered 1853, Bibliothèque Nationale de France, Paris, and a detail of Courbet's The Bathers, 1853, Musée Fabre, Montpellier.

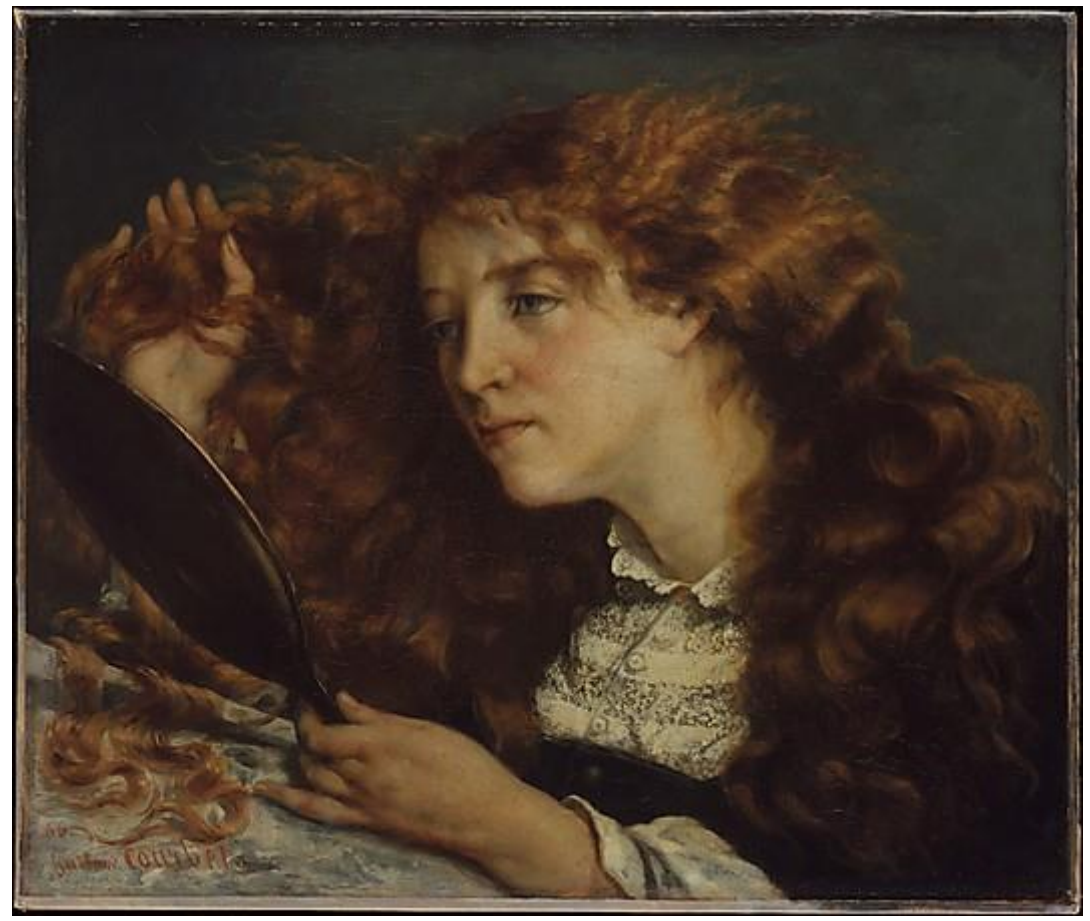

Figure 9: Gustave Courbet, Jo, La Belle Irlandaise, 1856-1866, oil on canvas, Metropolitan Museum of Art, New York. 


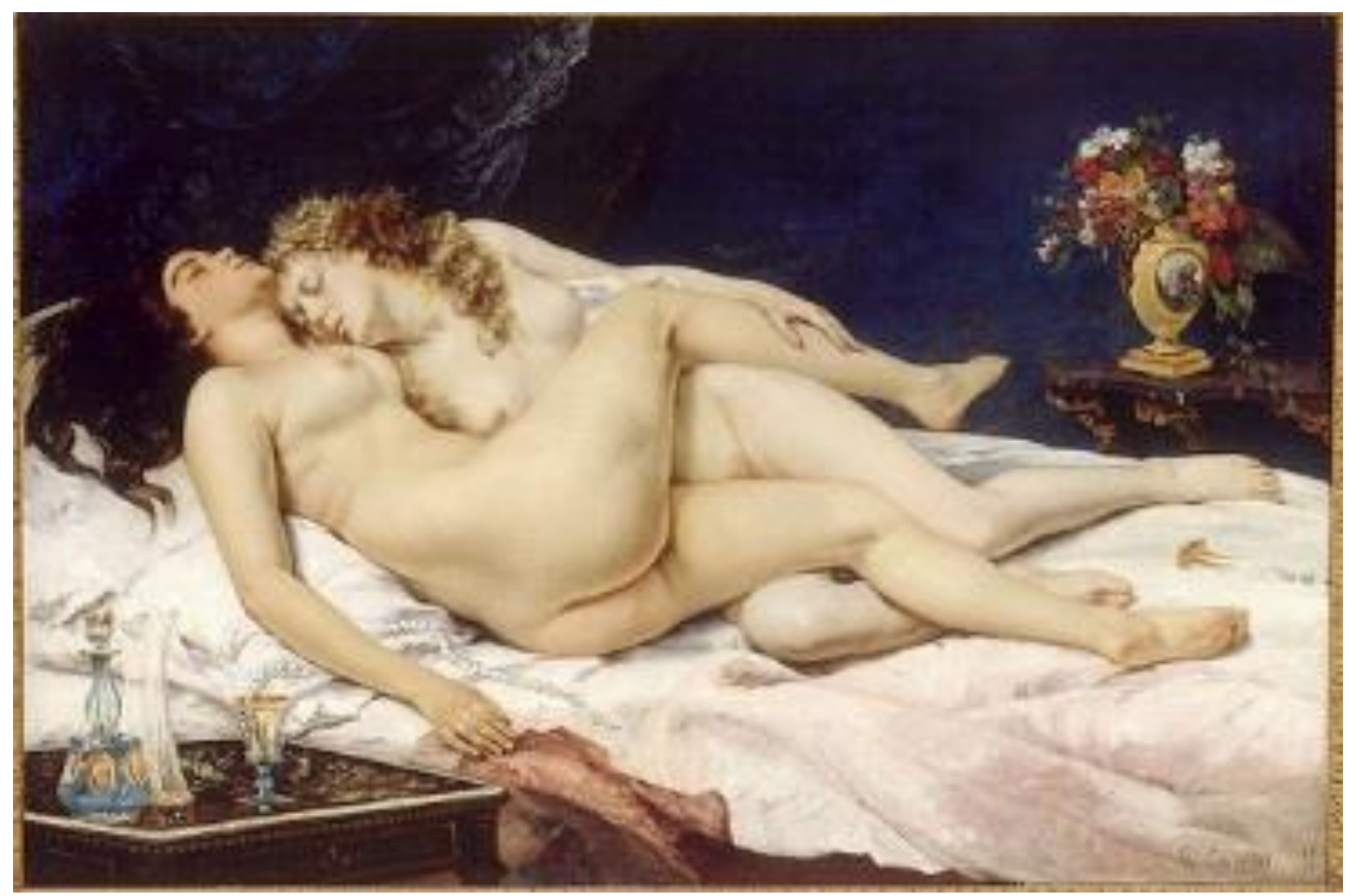

Figure 10: Gustave Courbet, The Sleepers, 1866, oil on canvas, Petit Palais, Paris.

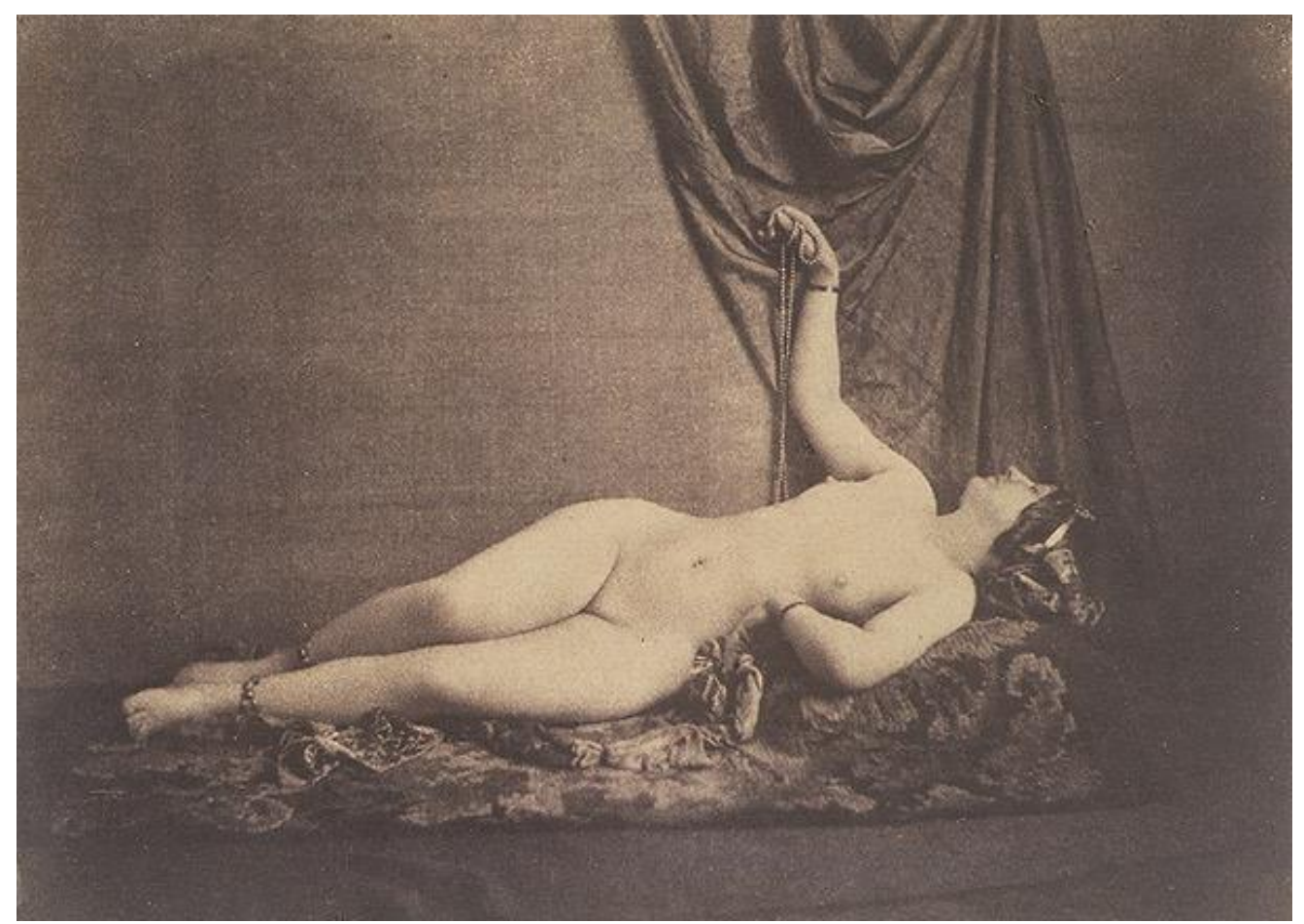

Figure 11: Julien Vallou de Villeneuve, Reclining Nude, daguerreotype, registered 1853, Metropolitan Museum of Art, New York. 


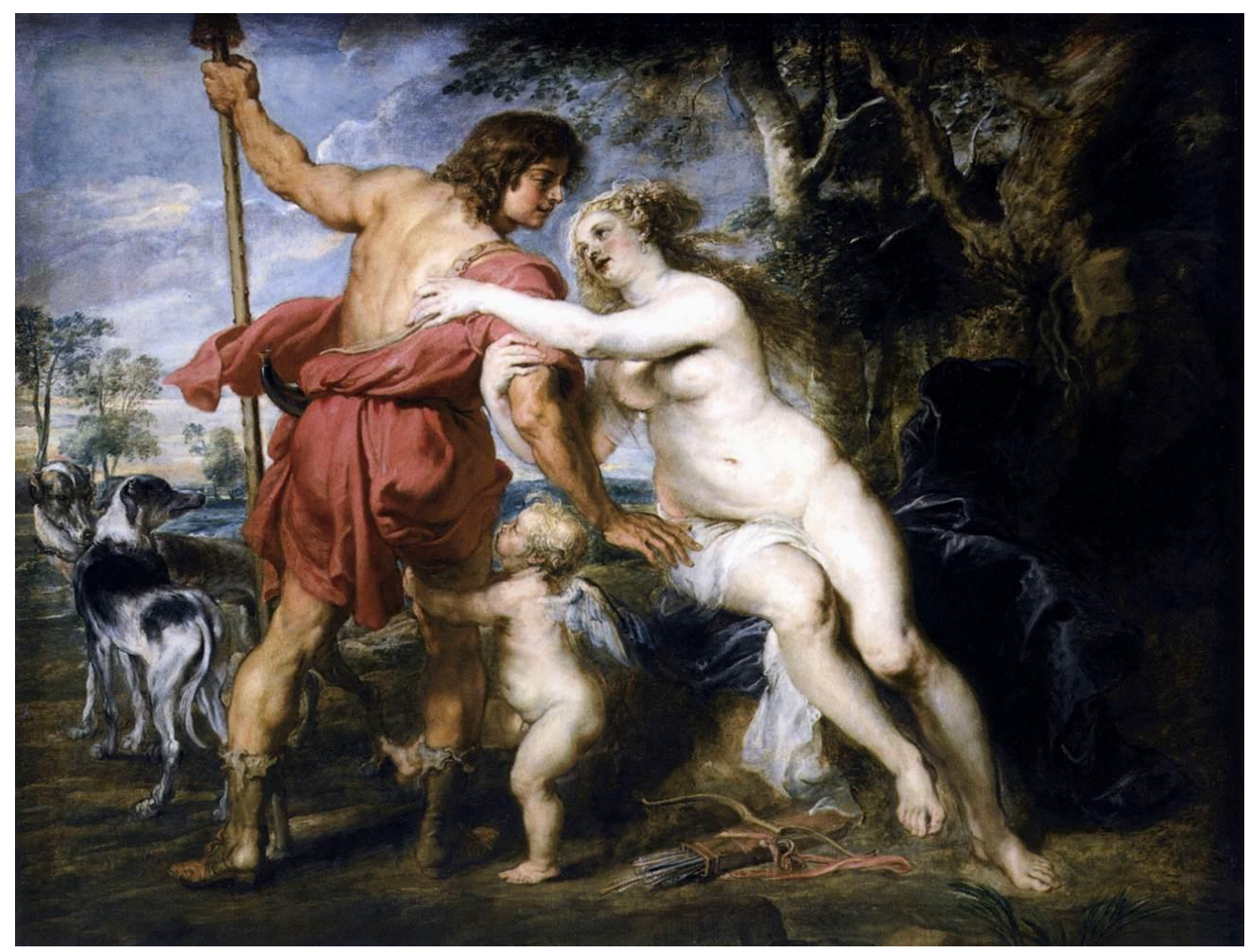

Figure 12: Peter Paul Rubens, Venus and Adonis s c.1635, oil on canvas, Metropolitan Museum of Art, New York.

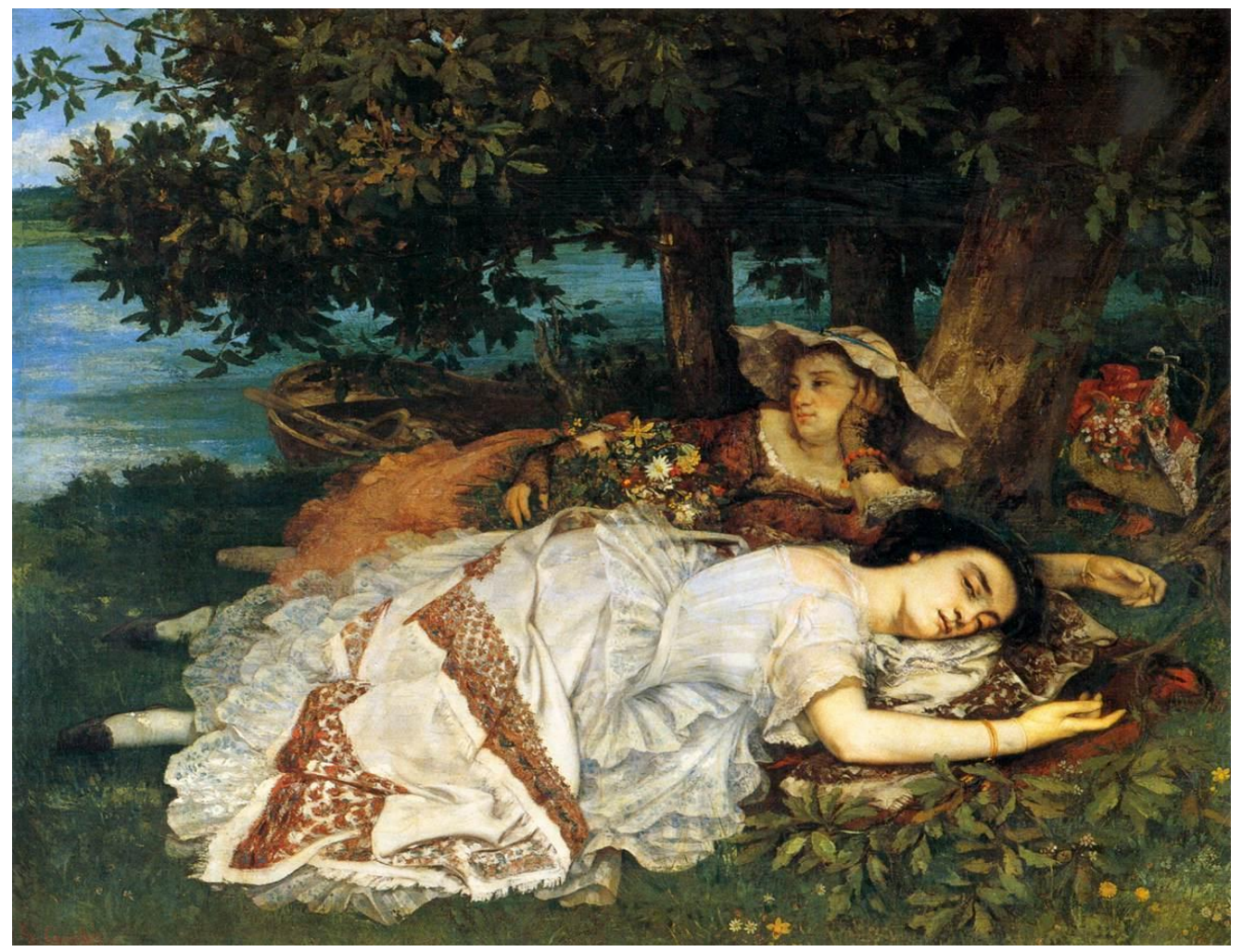

Figure 13: Gustave Courbet Young Ladies on the Banks of the Seine, 1857, oil on canvas, Musée du Petit Palais 


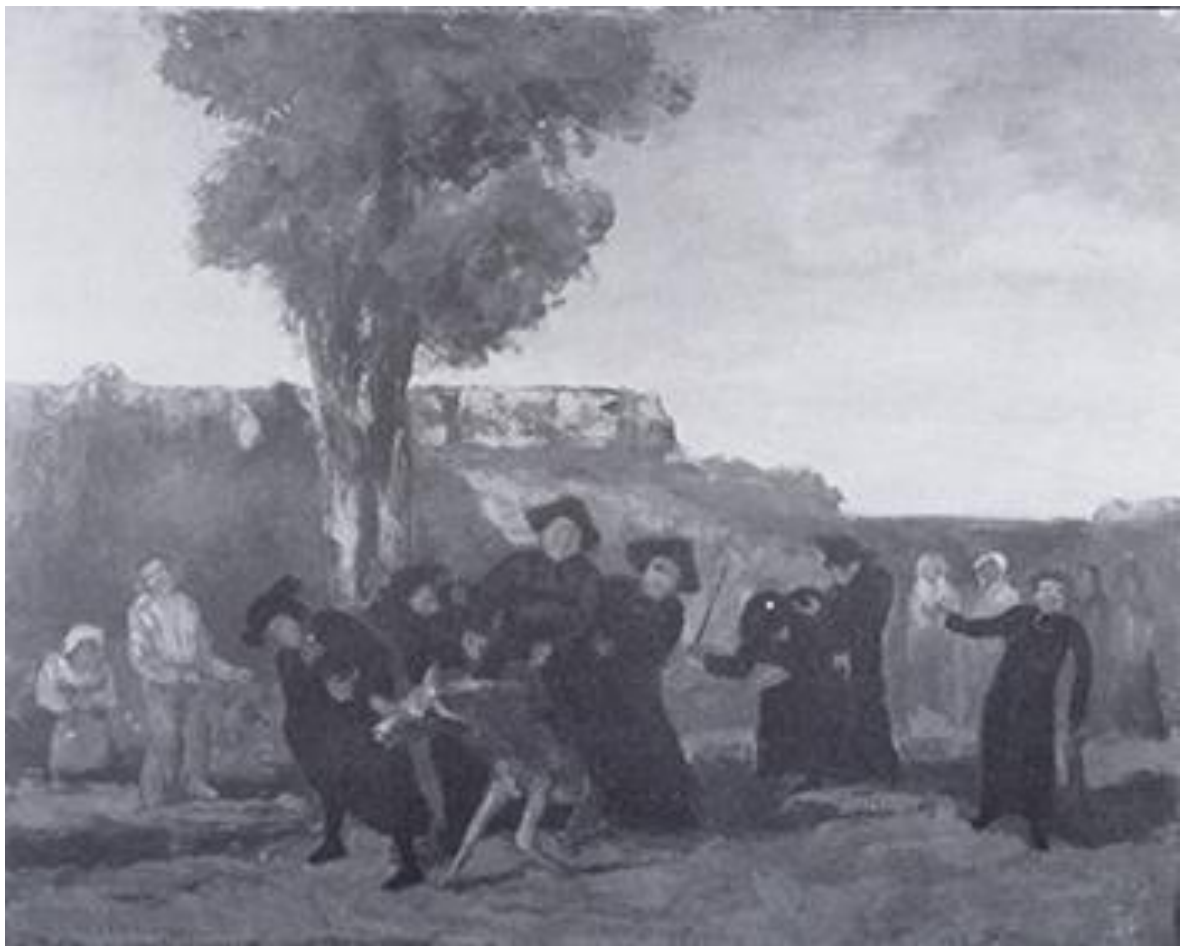

Figure 14: Gustave Courbet, Return from the Conference, 1863, drawing based on an original oil on canvas, whereabouts unknown.

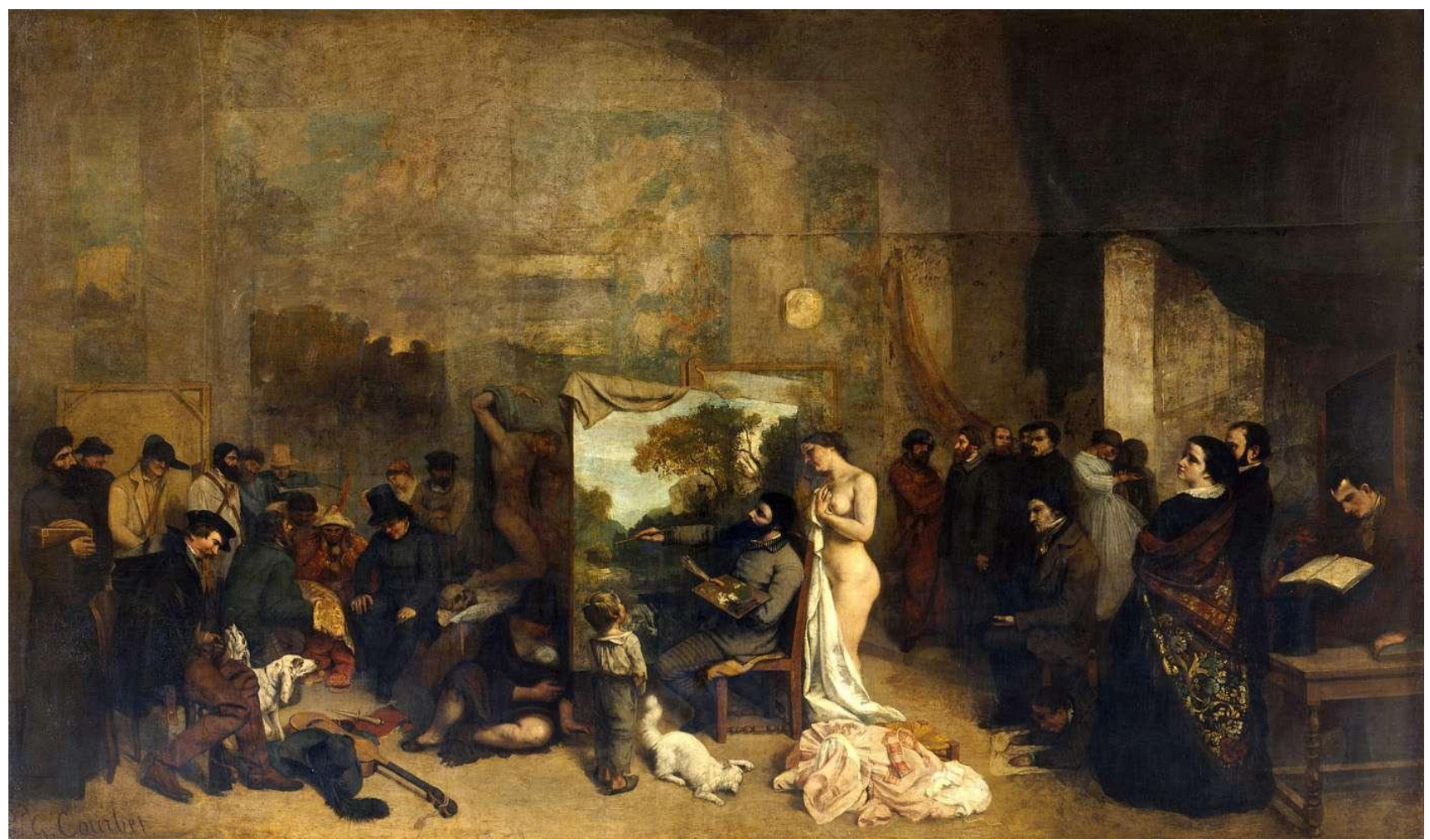

Figure 15: Gustave Courbet, The Artist's Studio, a real allegory summing up seven years of my artistic and moral life, 1854-1855, oil on canvas, Musée d'Orsay, Paris. 


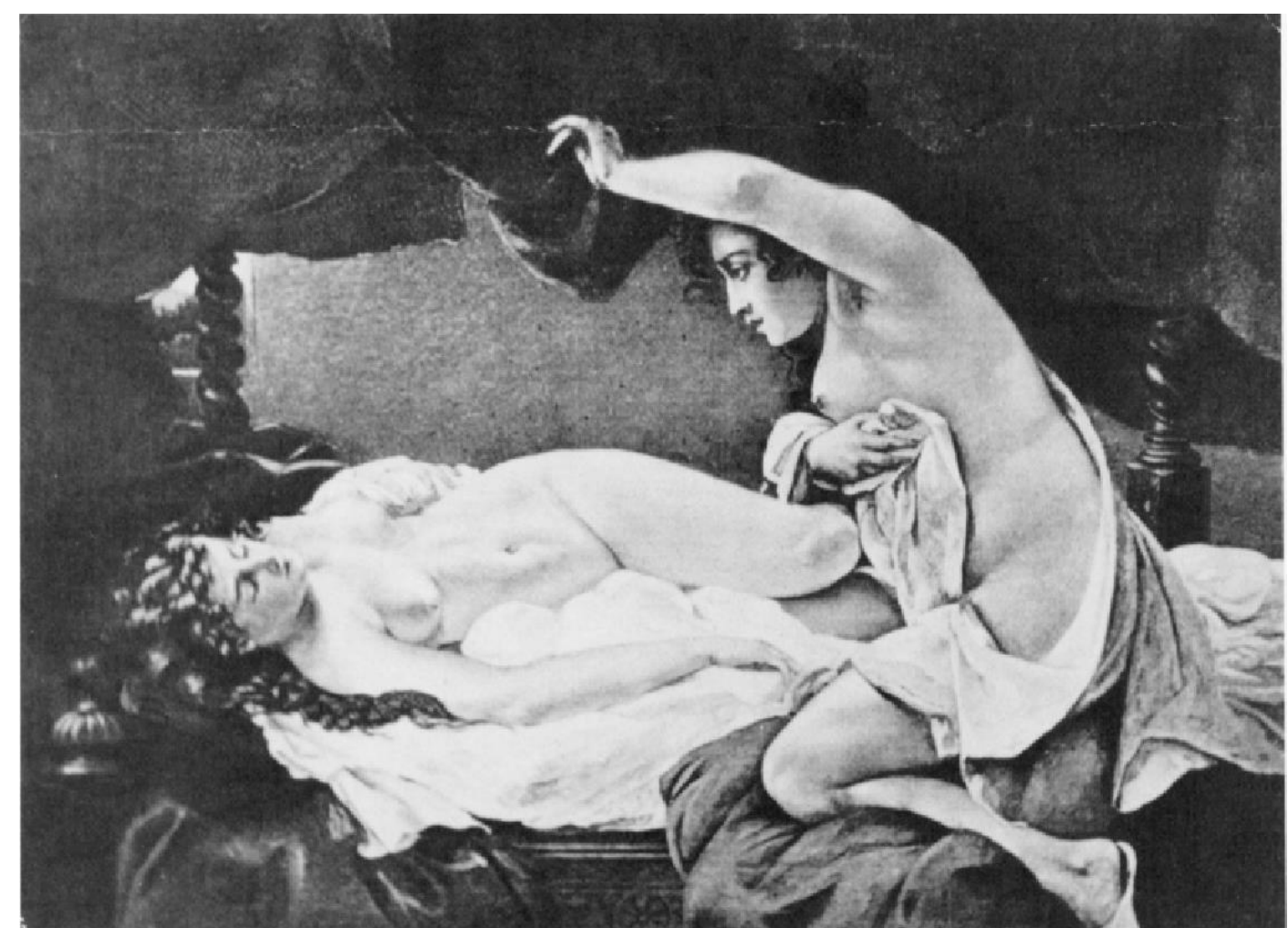

Figure 16: Gustave Courbet, Study of Women (Venus and Psyche), 1864, oil on canvas, location unknown.

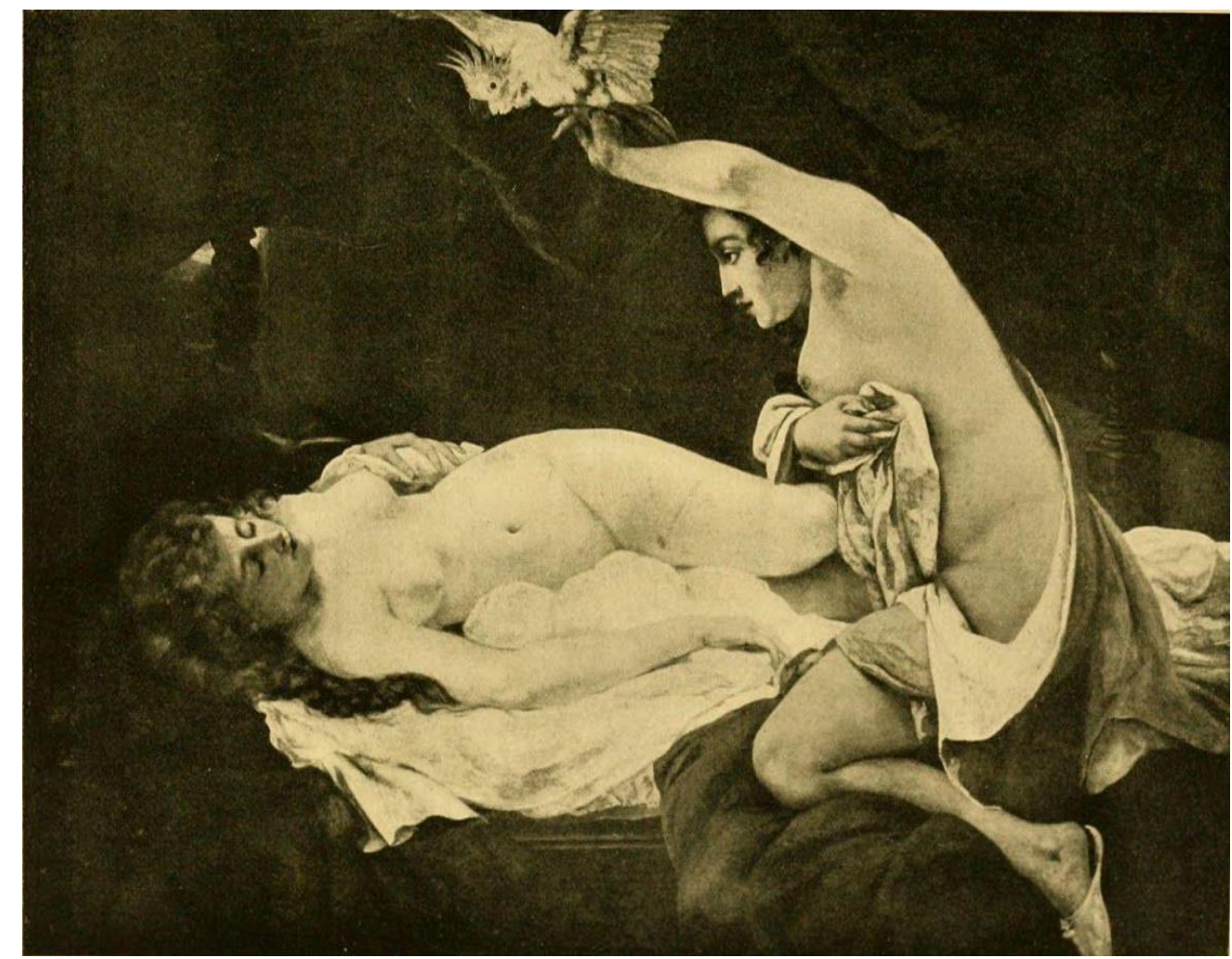

Figure 17: Gustave Courbet, The Awakening (originally titled Venus and Psyche before addition of bird), 1864, oil on canvas, location unknown. 


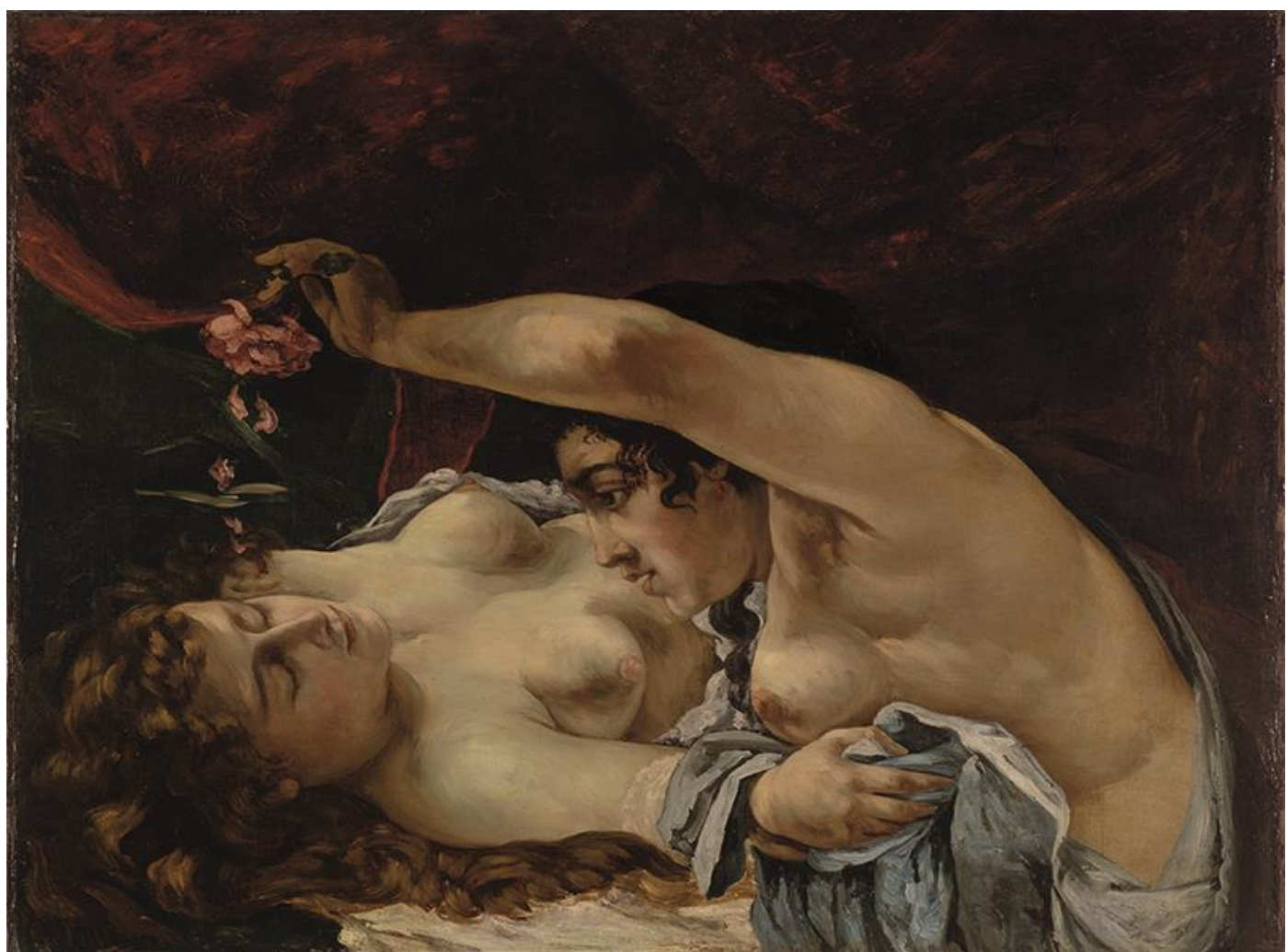

Figure 18: Gustave Courbet, Venus and Psyche, 1866, Kunstmuseum, Bern, Switzerland.

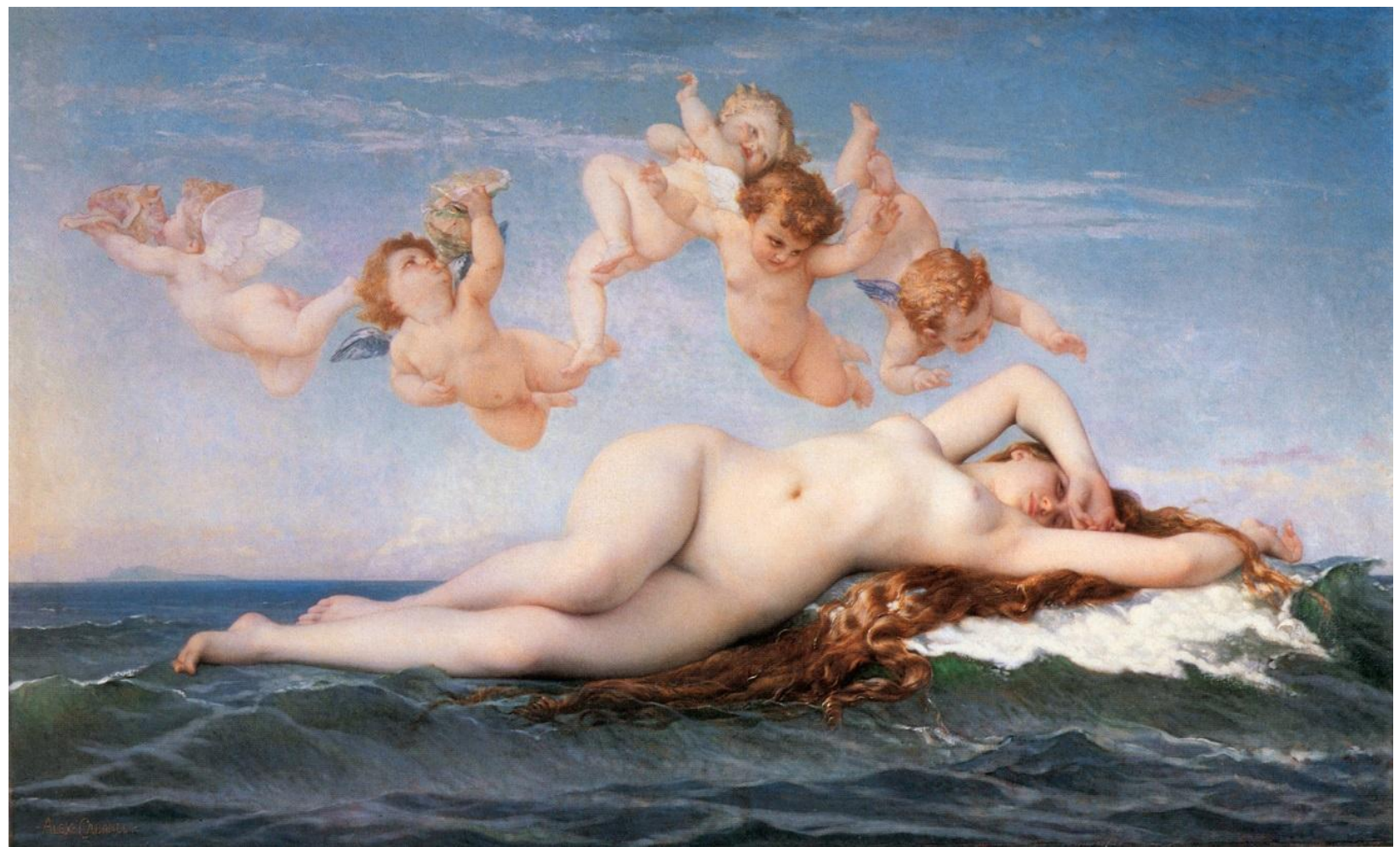

Figure 19: Alexandre Cabanel, The Birth of Venus, 1863, oil on canvas, Musée d'Orsay, Paris. 


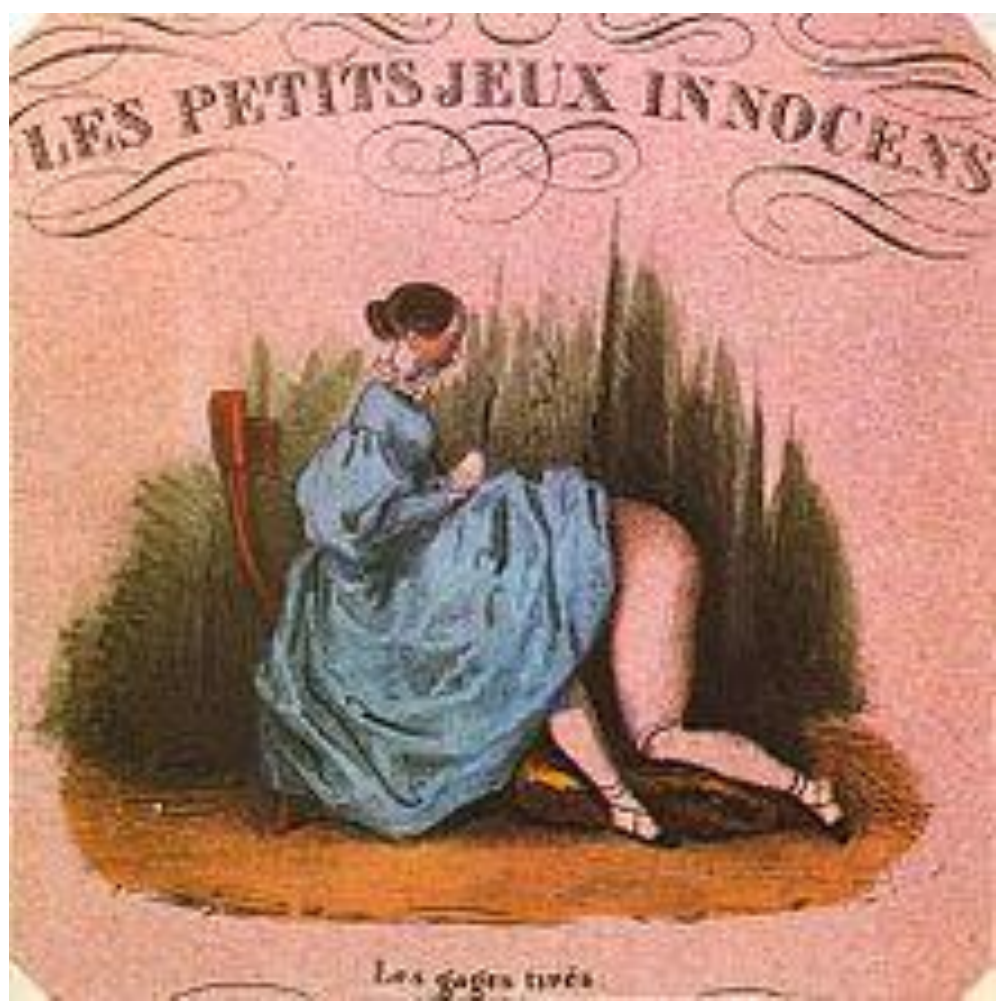

Figure 20: Achille Devéria, Les petits jeux innocens, Les gages tires, n.d., location unknown

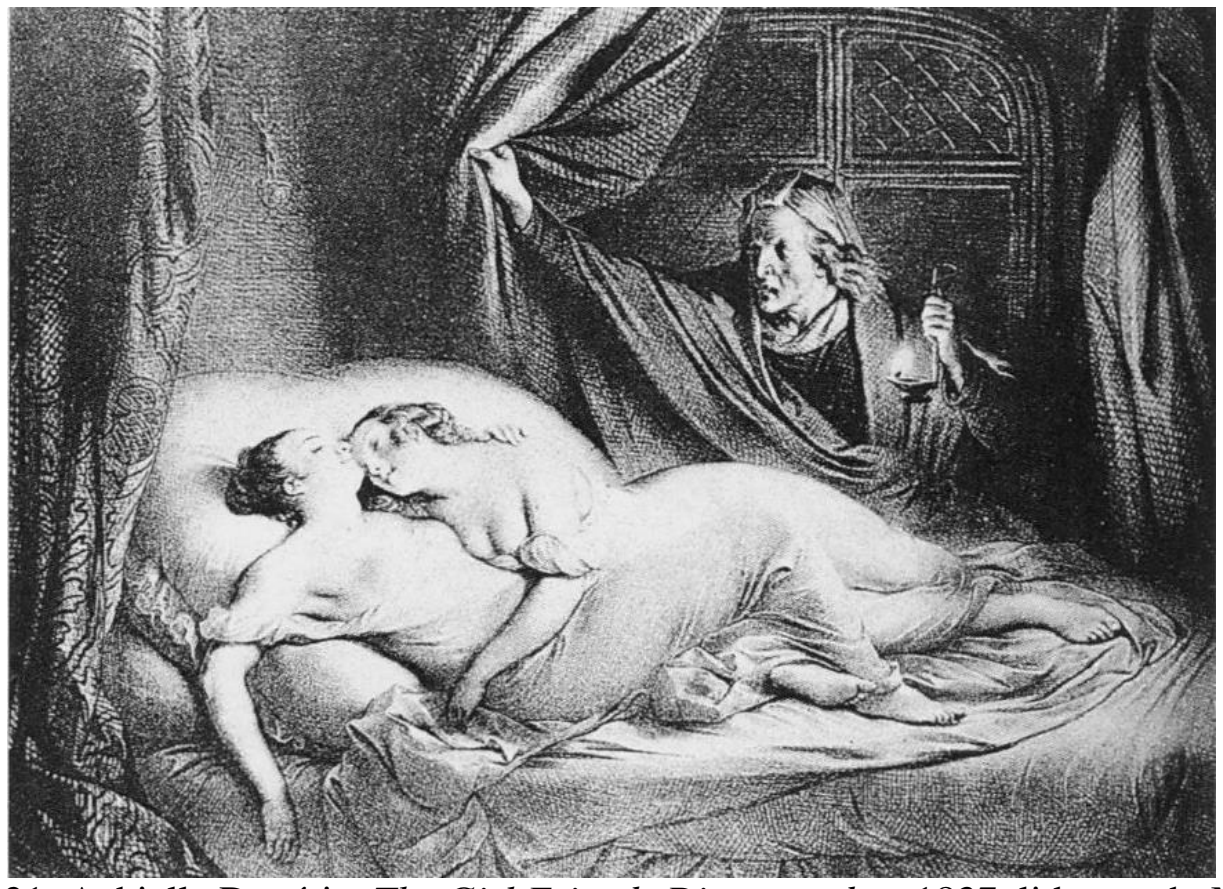

Figure 21: Achielle Devéria, The Girl Friends Discovered, c. 1837, lithograph, Musées Nationaux, Paris. 


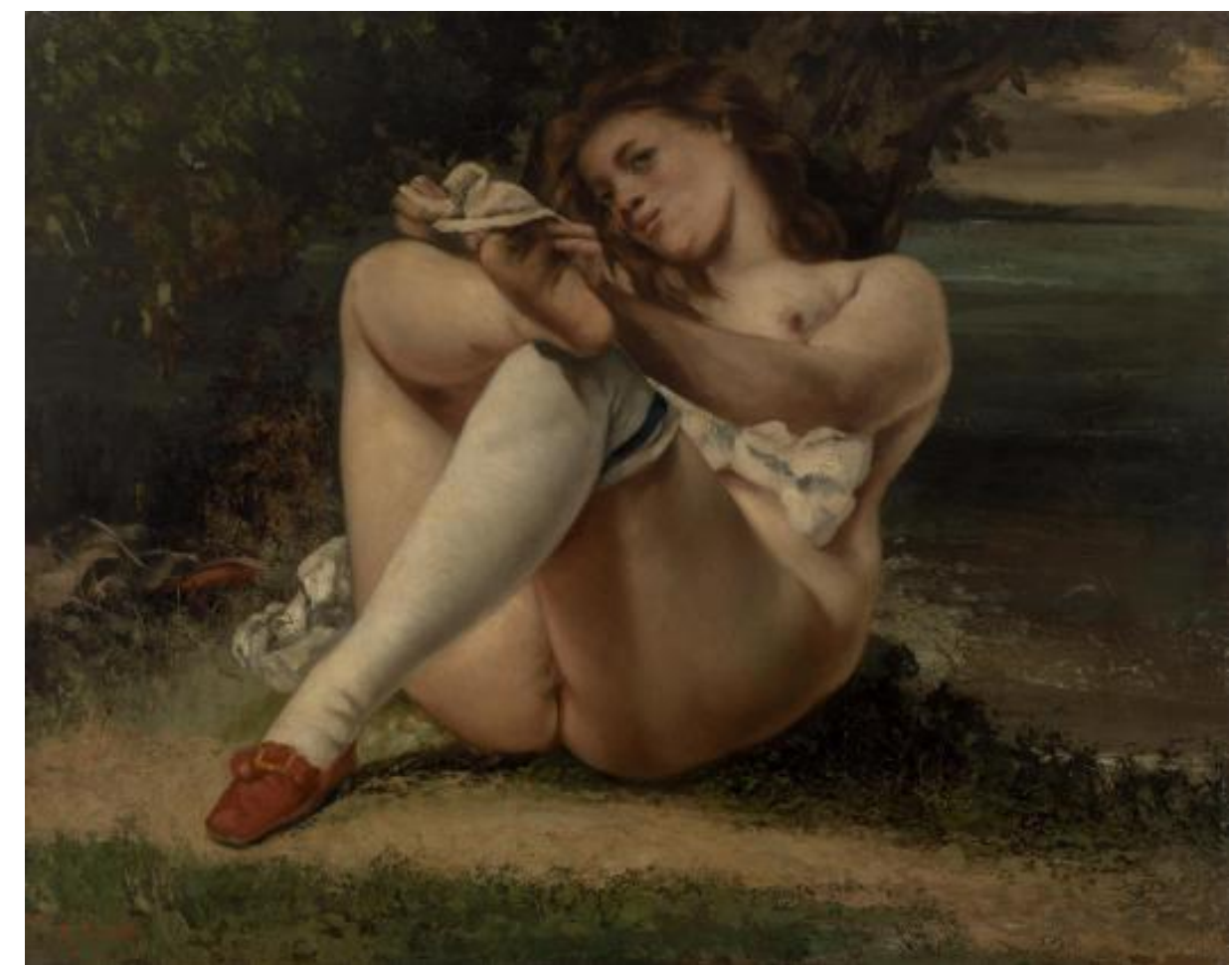

Figure 22: Gustave Courbet, Woman with White Stockings, 1864, oil on canvas, The Barnes Foundation, Philadelphia.

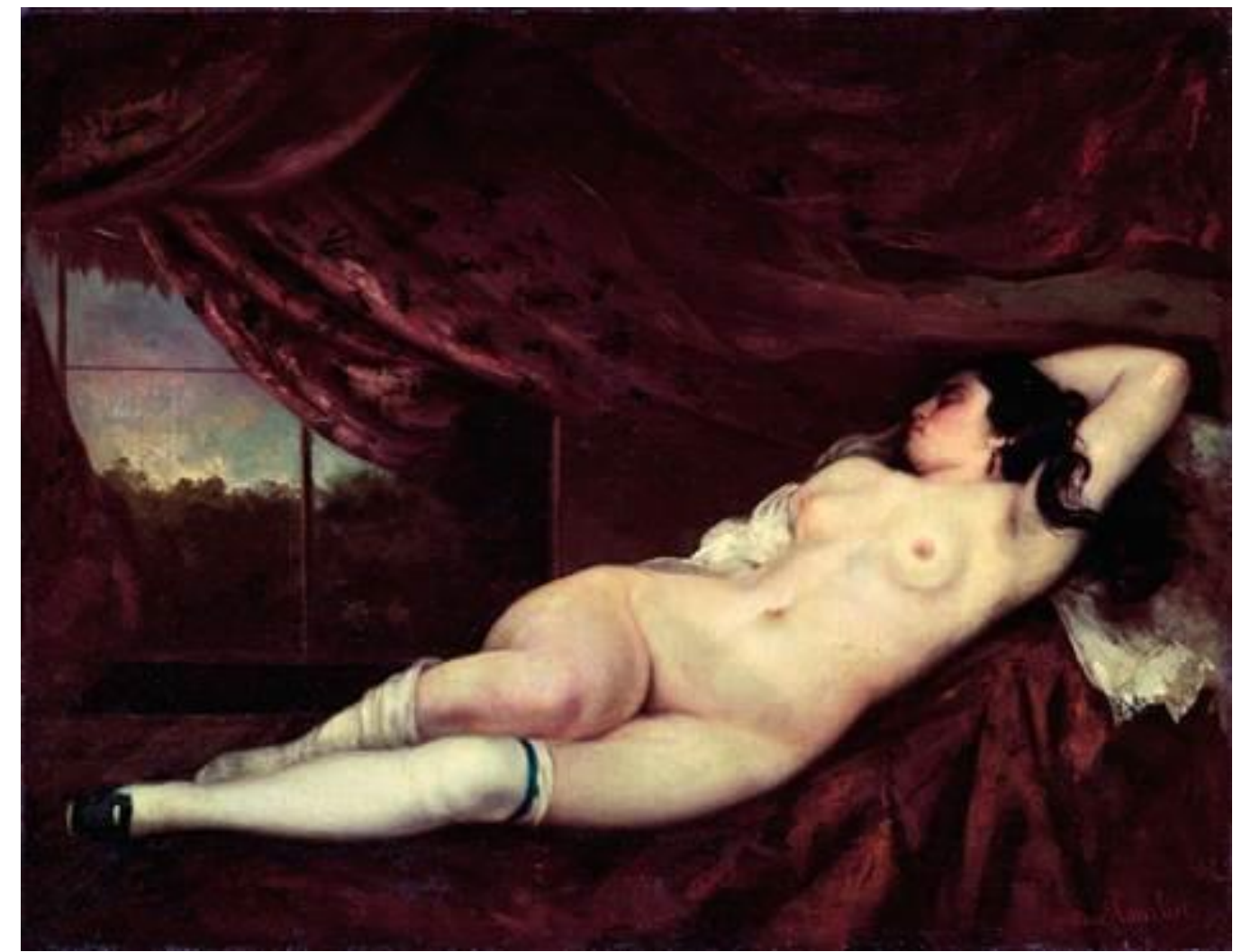

Figure 23: Gustave Courbet, Reclining Nude, 1862, oil on canvas, private collection. 


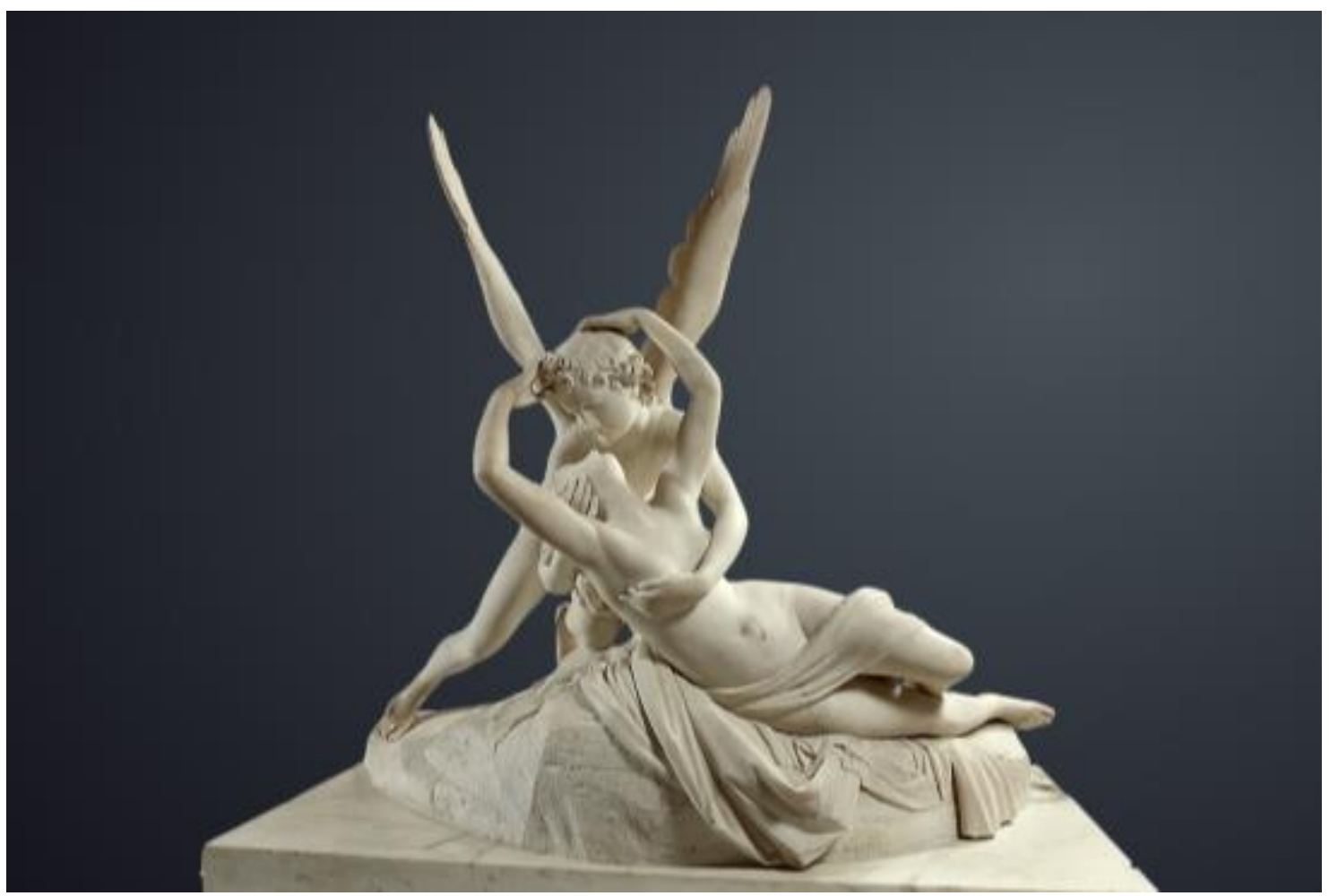

Figure 24: Antonio Canova, Psyche Revived by Cupid's Kiss, 1793, marble, Musée du Louvre, Paris.

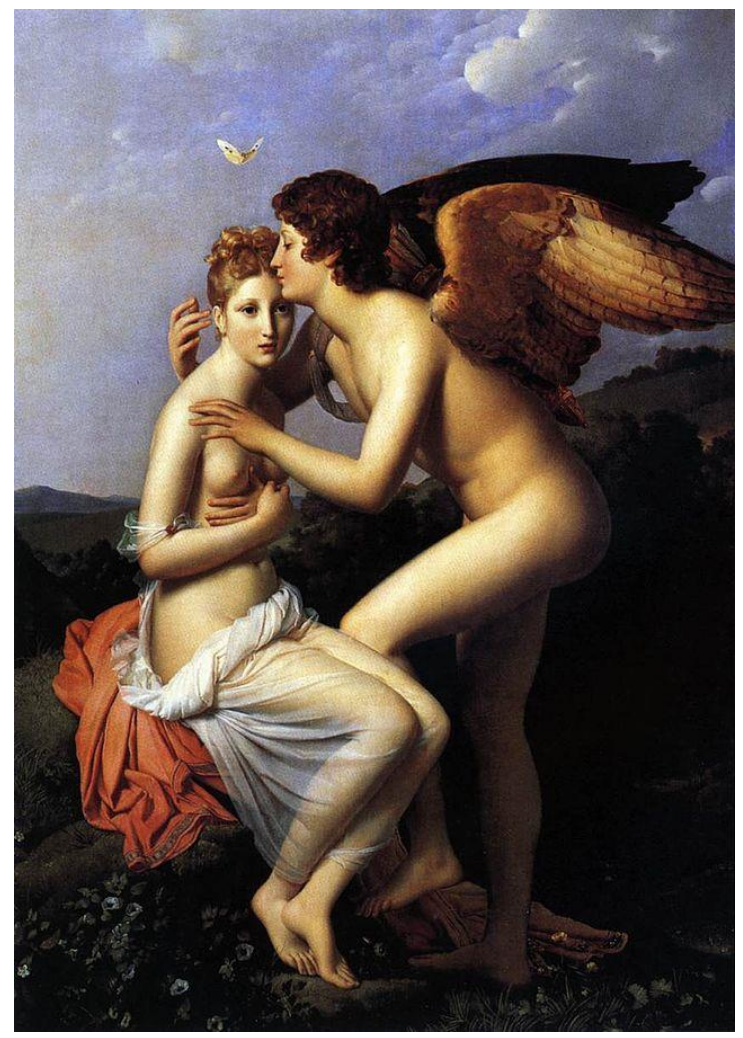

Figure 25: François Gérard's Psyche Receiving Cupid's First Kiss, 1798, oil on canvas, Musée du Louvre, Paris. 


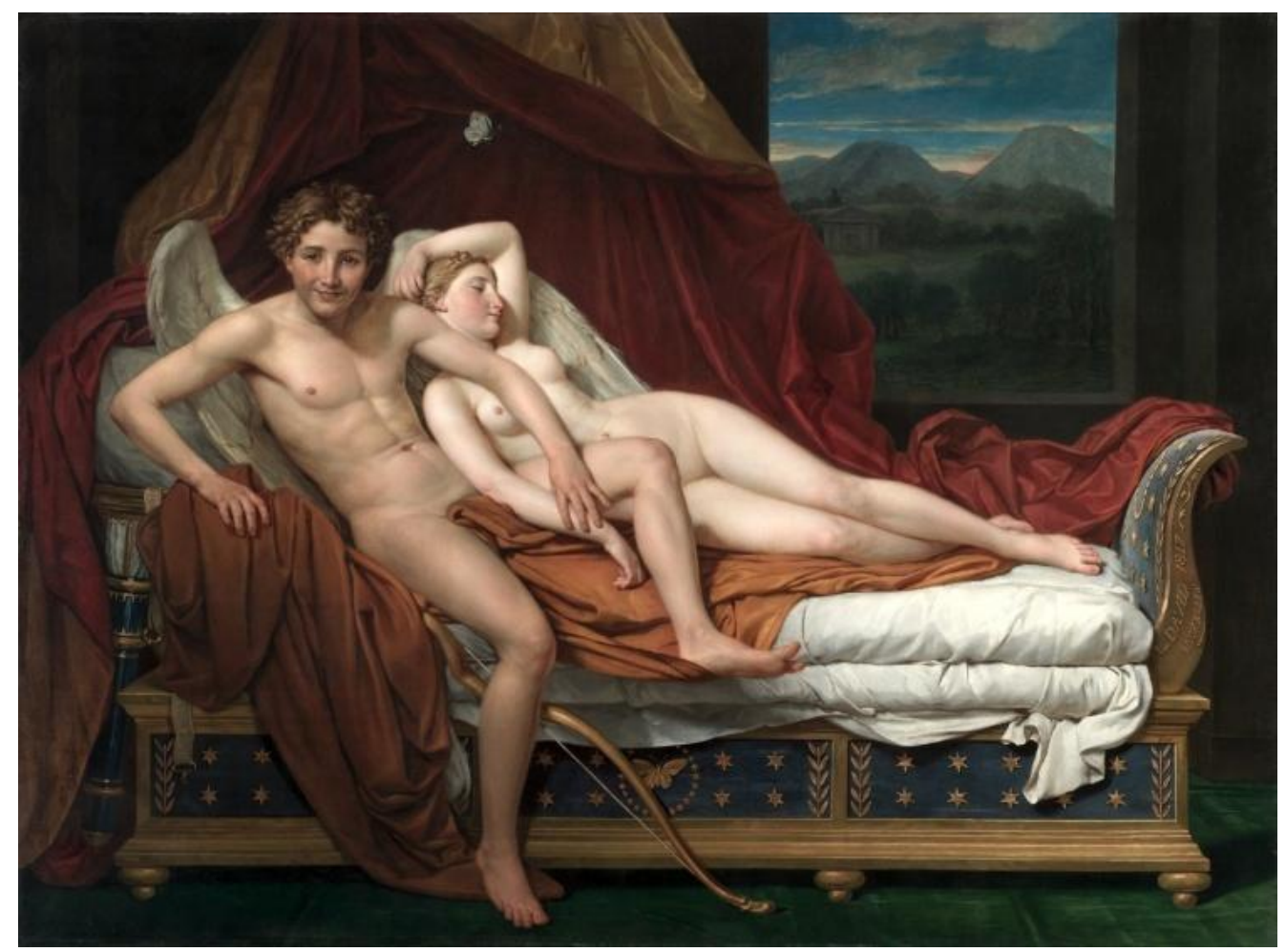

Figure 26: Jacques-Louis David, Cupid and Psyche, 1817, oil on canvas, Cleveland Museum of Art, Ohio.

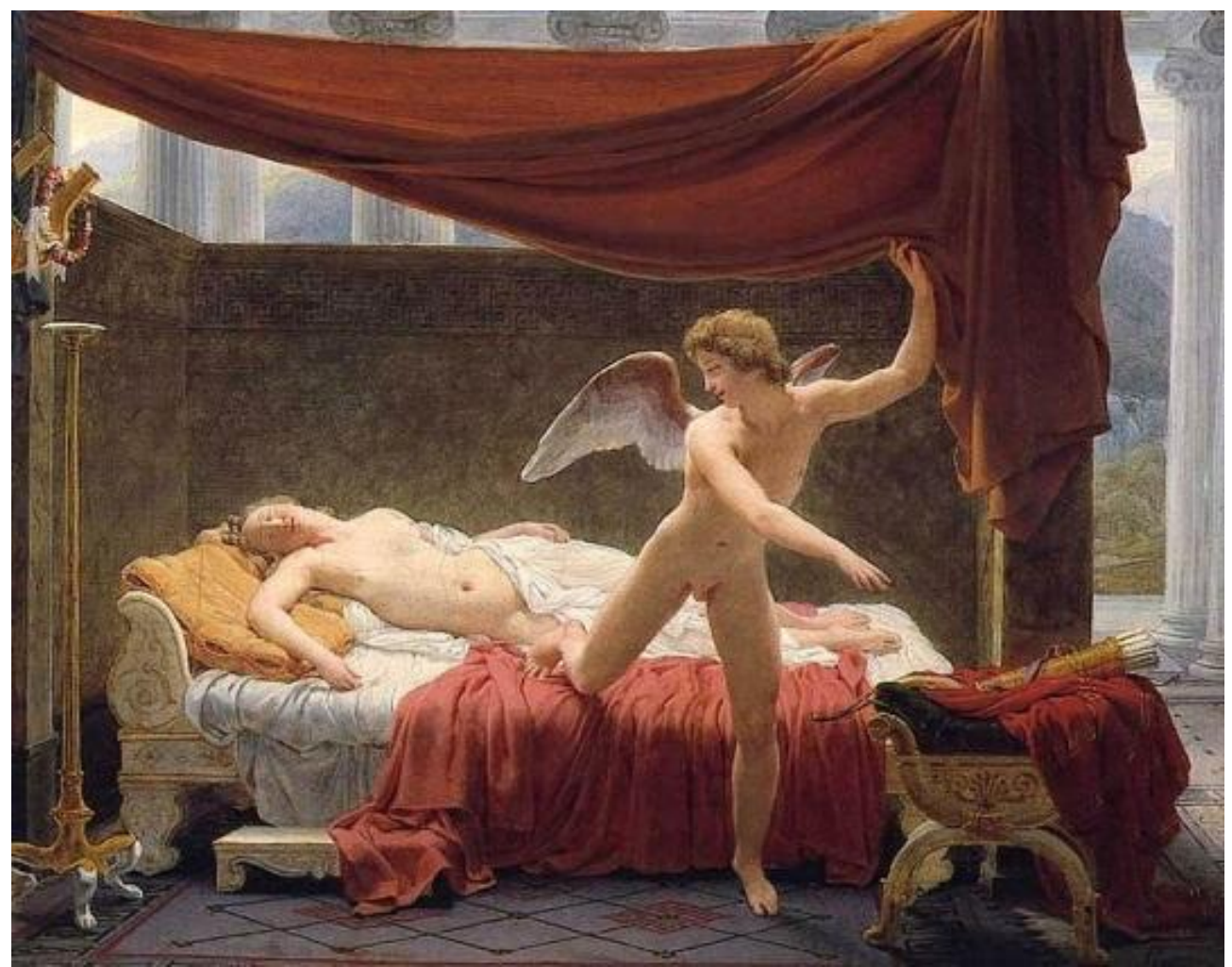

Figure 27: François Picot, Cupid and Psyche, c. 1817, oil on painting, Musée du Louvre, Paris. 


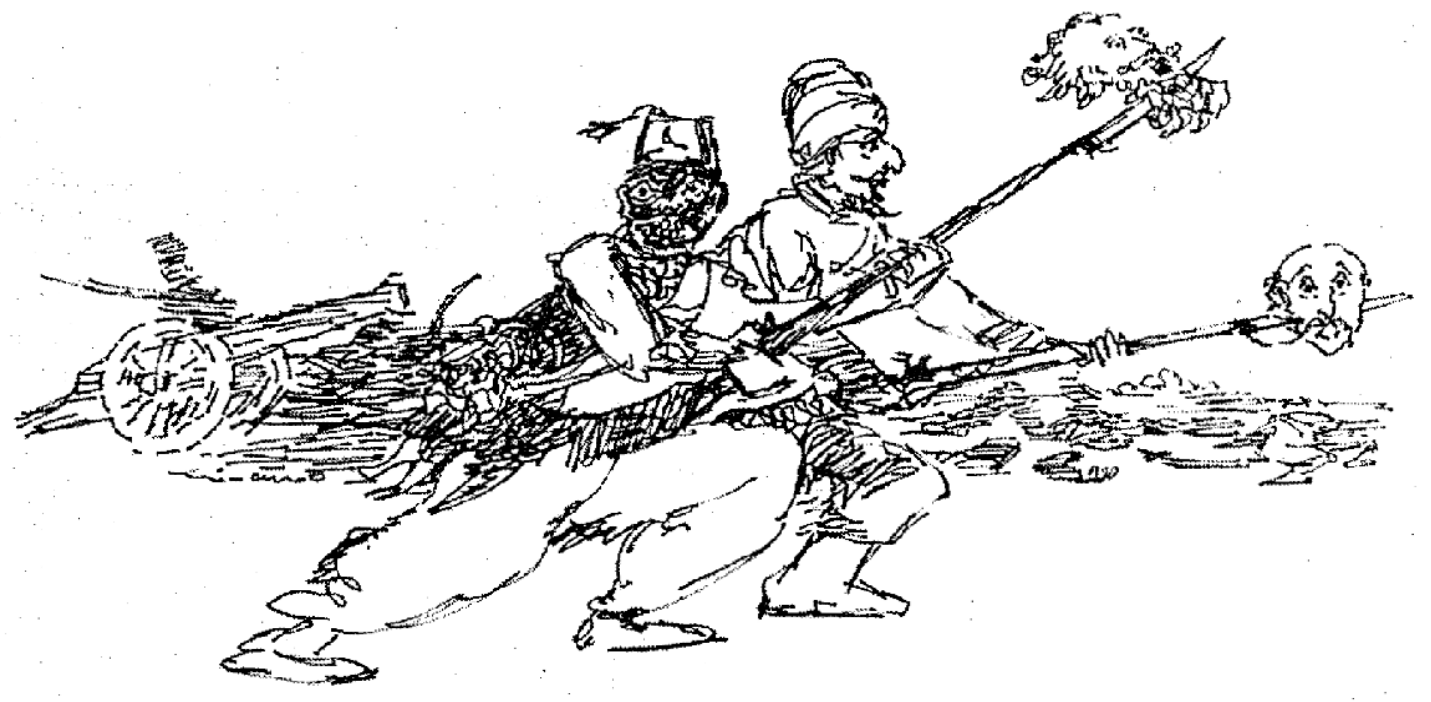

Figure 28: Gustave Courbet, Cemetery at Solferino, tentative reconstruction based on a description from Courbet. Petra ten-Doesschate Chu, "Courbet's Unpainted Pictures," Arts Magazine 55, (September, 1980): 140.

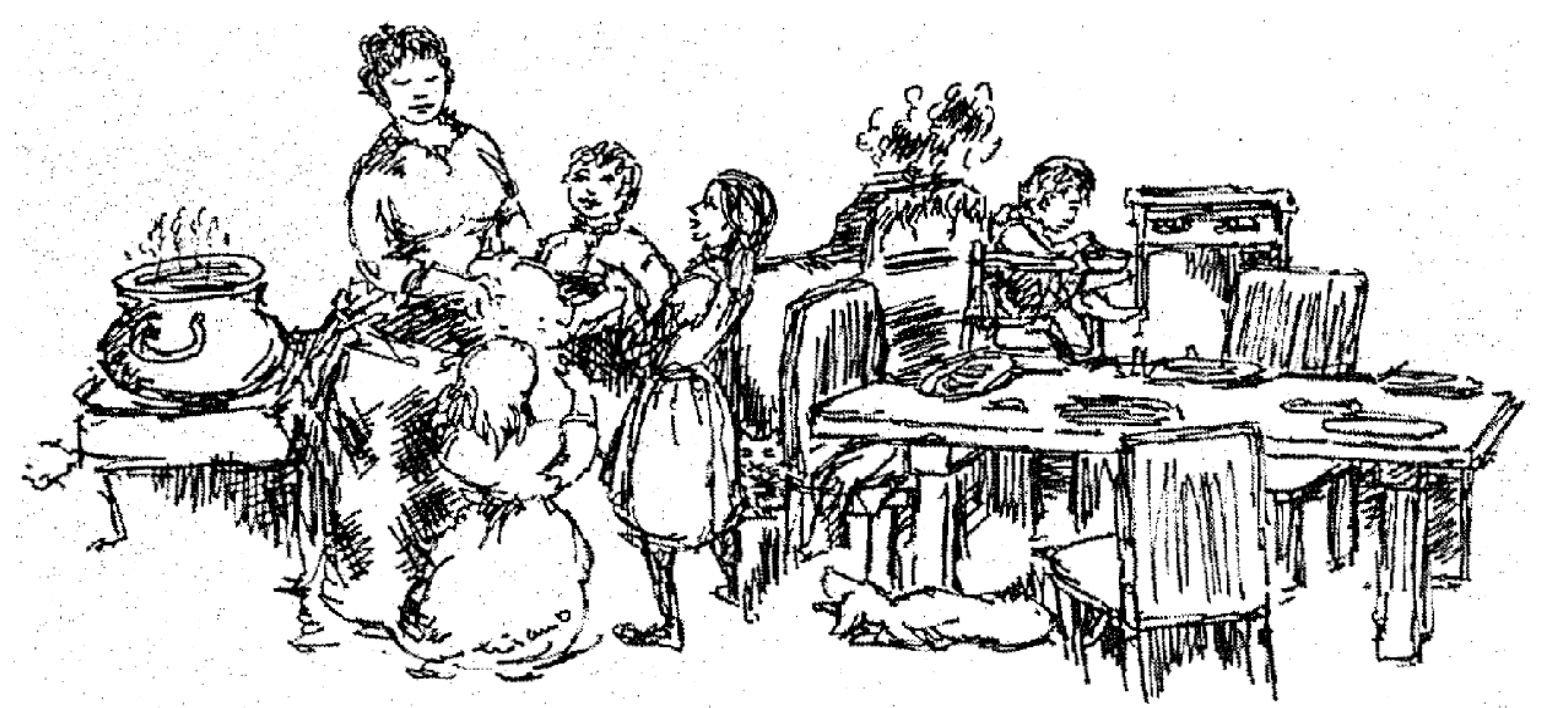

Figure 29: Gustave Courbet, Woman Kneading, tentative reconstruction based on a description from Courbet. Petra ten-Doesschate Chu, "Courbet's Unpainted Pictures," Arts Magazine 55, (September, 1980): 134. 


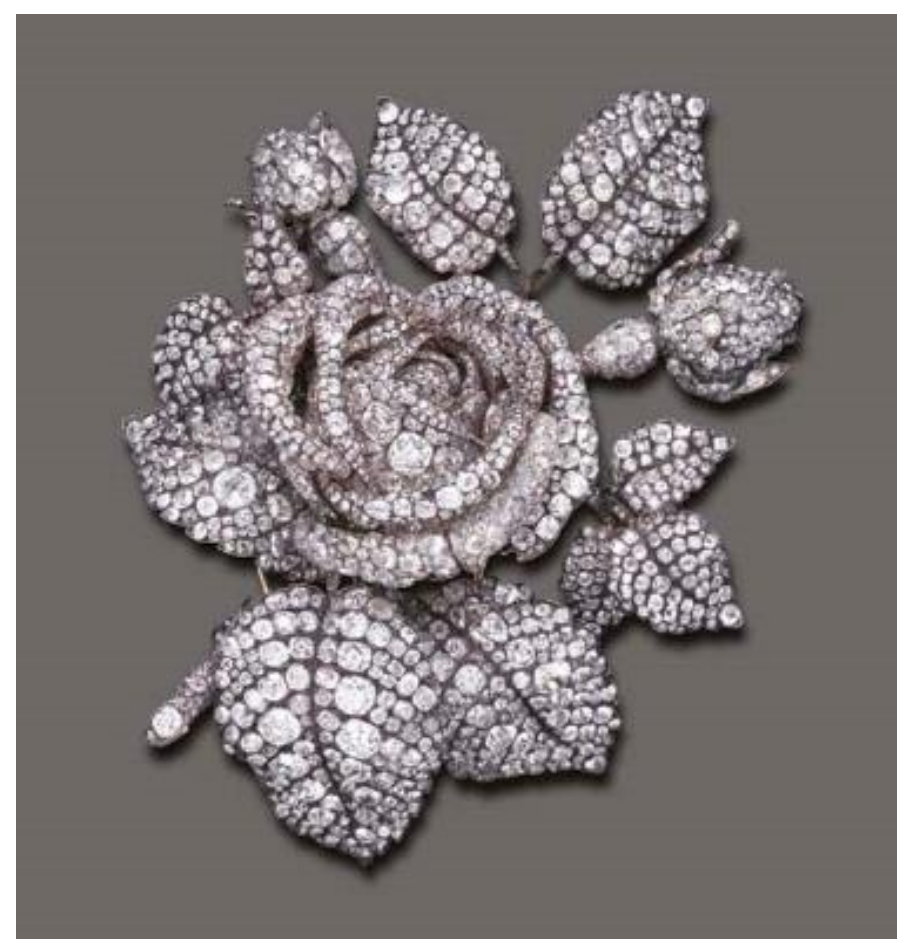

Figure 30: Tudor Rose brooch of Mathilde Bonaparte 


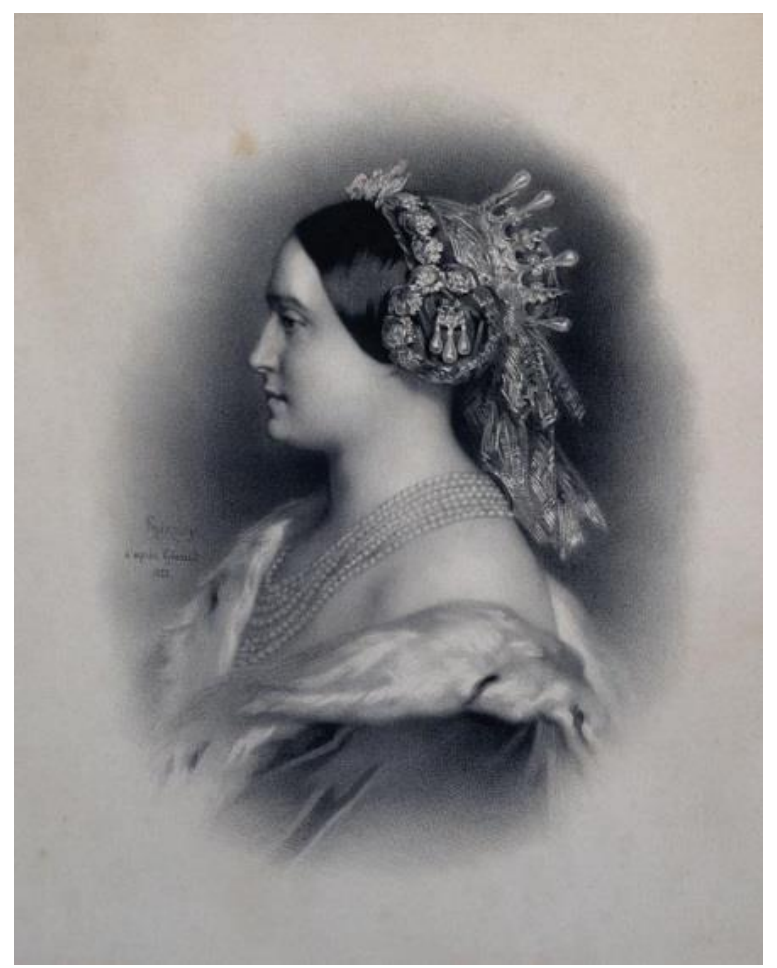

Figure 31: Portrait of Mathilde Bonaparte 


\section{BIBLIOGRAPHY}

The American Annual Cyclopedia and Register of Important Events of the Year 1868. vol. VIII, New York: D. Appleton and Company, 1871.

About, Edmond. Nos Artistes au Salon de 1857. Paris: L. Hachette et Cie., 1858.

Armbrust Siebert, Margaret. "A Political and a Pictorial Tradition Used in Gustave Courbet's Real Allegory." The Art Bulletin 65, no. 2 (1983): 311-316.

Berger, John. Ways of Seeing. London: Penguin, 2008.

Bierman, John. Napoleon III and His Carnival Empire. New York: St. Martin’s Press, 1988.

Boime, Albert. Art in an Age of Civil Struggle, 1848-1871. Chicago: University of Chicago Press, 2007.

. "An Unpublished Petition Exemplifying the Oneness of the Community of Nineteenth-Century French Artists." Journal of the Warburg and Courtauld Institutes 33 (1970): 345-353.

Bowness, Alan. “Courbet's Proudhon.” The Burlington Magazine 120, no. 900 (1978): 123-130.

Chu, Petra ten-Doesschate. The Most Arrogant Man in France: Gustave Courbet and the Nineteenth-Century Media Culture. Princeton: Princeton University Press, 2007.

. "Gustave Courbet's Venus and Psyche: Uneasy Nudity in SecondEmpire France.” Art Journal 51, no. 1 (Spring 1992): 38-44.

1980): 134-141.

. “Courbet's Unpainted Pictures.” Arts Magazine 55, (September,

Clark, Kenneth. The Nude. 1972. Reprint, Princeton, New Jersey: Princeton University Press, 1984.

Clark, T. J. Image of the People: Gustave Courbet and the 1848 Revolution. London: Thames \& Hudson, 1973.

. The Absolute Bourgeois: Artists and Politics in France 1848-1851. London: Thames and Hudson, 1973.

Courbet, Gustave. Letters of Gustave Courbet. Edited and translated by Petra ten-Doesschate Chu. Chicago: University of Chicago Press, 1992. 
Crapo, Paul B. "The Problematics of Artistic Patronage Under the Second Empire: Gustave Courbet's Involved Relations with the Regime of Napoleon III." Zeitschrift Fur Kunstgeschichte 2, no. 2 (1995): 240-261.

Dawkins, Heather. The Nude in French Art and Culture. 1870-1910. Cambridge, UK: Cambridge University Press, 2002.

Farwell, Beatrice. Woman as Sex Object: Studies in Erotic Art, 1730-1970. Edited by Thomas B. Hess and Linda Nochlin. New York/London: Allen Lane, 1973: 65-79.

Faunce, Sarah, Gustave Courbet, and Linda Nochlin. Courbet Reconsidered. Brooklyn: Brooklyn Museum, 1988.

Fernier, Robert. Gustave Courbet. New York: Frederick A. Praeger, Inc., Publishers, 1969.

La Vie et L'œuvre de Gustave Courbet: Catalogue Raisonné. Lausanne-Paris: Bibliothèque des Arts, 1977.

Floyd, Phyllis A. “The Puzzle of Olympia.” Nineteenth-Century Art Worldwide 3, no. 1 (Spring 2004). Accessed December 2, 2011. http://www.19thcartworldwide.org/index.php/spring04/285-the-puzzle-of-olympia.

Font-Réaulx, Dominique de. Gustave Courbet. New York: Metropolitan Museum of Art, 2008. Painting and Photography: 1839-1914. Paris: Flammarion, 2012.

Fried, Michael. Courbet's Realism. Chicago: University of Chicago Press, 1992.

Goldstein, Robert Justin. "Fighting French Censorship, 1815-1881." The French Review, vol. 71, no. 5, (April 1998): 785-796.

Hall, James. Dictionary of Subjects and Symbols in Art. New York: Harper \& Row, 1974.

Haskell, Francis. "A Turk and His Pictures in Nineteenth-Century Paris." Oxford Art Journal 5, no. 1 (1982): 40-47.

Hamilton, Edith. Mythology: Timeless Tales of Gods and Heros. New York: Grand Central Publishing, 1942.

Harrison, Charles, ed., Paul Wood, and Jason Gaiger. Art in Theory: 1815-1900 An Anthology of Changing Ideas. Oxford: Blackwell Publishers, 2001.

Harmuth, Louis. Dictionary of Textiles. New York: Fairchild Publishing Company, 1915

Kimball, Roger. The Rape of the Masters: How Political Correctness Sabotages Art. San Francisco: Encounter Books, 2004. 
King, Ross. The Judgment of Paris: The Revolutionary Decade That Gave the World Impressionism. New York: Walker \& Co., 2006.

Kosinski, Dorothy M. “Gustave Courbet's The Sleepers: The Lesbian Image in NineteenthCentury French Art and Literature.” Artibus et Historiae 18 (1988): 187-199.

Læssøo, Rolf, “Édouard Manet's 'Le Déjeuner sur l'herbe' as a Veiled Allegory of Painting.” Artibus et Historiae 12, no. 51 (2005): 195-220.

Lacambre, Genevieve, Rodolphe Rapetti, Antoinette Le Normand-Romain, Anne Pingeot, Philippe Neagu, Francoise Heilbrun, Marc Bascou, Philippe Thiebaut, Caroline Matheiu, and Georges Vigne. Arts of the 19th century, 1850 to 1905. Edited by Francoise Cachin. Vol. 2. New York: Harry N. Abrams, Inc., Publishers, 1999.

Lauter, Devorah. "Has the Head of the Origin of the World Been Found?" The Telegraph. Last modified February 10, 2013. Accessed October 6, 2014. http://www.telegraph.co.uk/culture/art/9860793/Has-the-head-of-The-Origin-ofthe-World-been-found.html.

Le Man, Ségolène. Courbet. New York: Abbeville Press Publishers, 2008.

Lessing, Erich and Vincent Pomarède. The Louvre: All the Paintings. New York: Black Dog \& Leventhal Publishers, 2011.

Lesko, Diane. "From Genre to Allegory in Gustave Courbet's Les Demoiselles de Village," Art Journal, vol. 38, no. 3, (Spring, 1979): 171-177.

Levine, Steven Z. “Courbet, Bronzino and Blasphemy,” New Literary History, volume 22, no. 3, (Summer, 1991): 677-714.

Lindsay, Jack. Gustave Courbet: His Life and Art. London: Harper \& Row Publishers, 1973.

McCarthy, James C. "Courbet's Ideological Contradictions and the Burial at Ornans." Art Journal, 35, no. 1 (Autumn, 1975): 12-16.

Mack, Gerstle. Gustave Courbet. New York: Alfred A. Knopf, 1951.

Mainardi, Patricia. Art and Politics of the Second Empire: The Universal Expositions of 1855 and 1867. New Haven: Yale University Press, 1987.

Moffitt, John F. "Art and Politics: The Underlying Pictorial - Political Topos in Courbet's "Real Allegory"." Artibus et Historiae vol. 8, no. 15 (1987): 183-193.

Nead, Lynda. The Female Nude: Art, Obscenity, and Sexuality. London: Routledge, 1992. 
335.

. “The Female Nude: Pornography, Art, and Sexuality.” Signs 15, no. 2 (1990): 323-

Nochlin, Linda. Courbet. London: Thames \& Hudson, 2007.

. "The De-Politicization of Gustave Courbet: Transformation and Rehabilitation under the Third Republic." October 22 (Autumn 1982): 64-78.

. The Politics of Vision: Essays on Nineteenth-century Art and Society. Boulder, CO: Westview Press, 1991.

. Women, Art, and Power: And Other Essays. New York: Harper \& Row, 1989.

Pollock, Griselda. Vision and Difference: Femininity, Feminism and Histories of Art. London: Routledge, 1988.

. Visual Politics of Psychoanalysis: Art in Post-Traumatic Cultures. London:

I.B. Tauris, 2013.

Proudhon, Pierre-Joseph. Du Principe de l'Art et de sa Destination Sociale. Paris: Garnier Fréres, Libraries-Éditeurs, 1865.

O'Connell, Richard Vincent. "Art at the Barricades: Courbet and Proudhon, The Trajectory of an Asymmetrical Relationship,” Masters thesis, University of Colorado Denver, 2011.

Reilly, Maura. "Le Vice à la Mode: Gustave Courbet and the Vogue for Lesbianism in Second Empire France.” PhD diss., New York University, 2000.

Rothenstein, John. Nineteenth-Century Painting: A Study in Conflict. Freeport, New York: Books for Libraries Press, Inc., 1932.

Rubin, James Henry. Realism and Social Vision in Courbet \& Proudhon. Princeton, New Jersey: Princeton University Press, 1980.

Samuel, Henry. "Amateur art buff finds $£ 35$ million head of Courbet masterpiece." The Telegraph. Last modified February 7, 2013. Accessed February 8, 2013. http://www.telegraph.co.uk/news/worldnews/europe/france/9854914/Amateur-art-bufffinds-35-million-head-of-Courbet-masterpiece.html.

Sand, Georges. Lélia. Paris: Michel Lévy Fréres, Libraries Éditeurs, 1867. Accessed January 26, 2014. http://www.gutenberg.org/files/39738/39738-h/39738-h.htm.

Shaw, Jennifer L. "The Figure of Venus: Rhetoric of the Ideals and the Salon of 1963." In Manifestations of Venus: Art and Sexuality. Edited by Caroline Arscott and Katie Scott. Manchester: Manchester University Press, 2000. 
Taylor, Joshua C. edit. Nineteenth-Century Theories of Art. Berkeley, CA: University of California Press, 1987.

Toussaint, Hélène et al. Gustave Courbet: 1819-1877: [an exhibition organized by the Réunion des musées nationaux], at the Royal Academy of Arts, 19 January-19 March 1978. London: Arts Council of Great Britain, 1978.

Vicinus, Martha. “"'The Wonder to Which Sex I Belong": The Historical Roots of the Modern Lesbian Identity." Feminist Studies vol. 18, no. 3 (Autumn 1992): 467-497. 